UNIVERSIDADE DE SÃO PAULO

FACULDADE DE FILOSOFIA, LETRAS E CIÊNCIAS HUMANAS

DEPARTAMENTO DE LETRAS MODERNAS

PROGRAMA DE PÓS-GRADUAÇÃO EM LÍNGUA, LITERATURA E CULTURA ITALIANAS

EMANUEL FRANÇA DE BRITO

A insaciável sede de saber na Comédia de Dante

Algumas relações com a incontinência aristotélica 
UNIVERSIDADE DE SÃO PAULO

FACULDADE DE FILOSOFIA, LETRAS E CIÊNCIAS HUMANAS DEPARTAMENTO DE LETRAS MODERNAS

PROGRAMA DE PÓS-GRADUAÇÃO EM LÍNGUA, LITERATURA E CULTURA ITALIANAS

\title{
A insaciável sede de saber na Comédia de Dante Algumas relações com a incontinência aristotélica
}

\author{
Emanuel França de Brito
}

Dissertação apresentada ao Programa de PósGraduação em Língua, Literatura e Cultura Italianas do Departamento de Letras Modernas da Faculdade de Filosofia, Letras e Ciências Humanas da Universidade de São Paulo, para obtenção do título de Mestre em Letras.

Orientadora: $\operatorname{Prof}^{\mathrm{a}} \operatorname{Dr}^{\mathrm{a}}$ Vilma de Katinszky Barreto de Souza

VERSÃO CORRIGIDA

São Paulo

2010 
Autorizo a reprodução e divulgação total ou parcial deste trabalho, por qualquer meio convencional ou eletrônico, para fins de estudo e pesquisa, desde que citada a fonte.

Catalogação da Publicação 
FOLHA DE APROVAÇÃ̃O

Nome: BRITO, Emanuel França de

Título: A insaciável sede de saber na Comédia de Dante. Algumas relações com a incontinência aristotélica

Dissertação apresentada ao Departamento de Letras Modernas da Faculdade de Filosofia, Letras e Ciências Humanas da Universidade de São Paulo para obtenção do título de Mestre. Área de Concentração: Língua e Literatura Italiana.

Aprovado em:

Banca examinadora

Prof. Dr.

Instituição:

Julgamento:

Assinatura:

Prof. Dr.

Instituição:

Julgamento:

Assinatura:

Prof. Dr.

Instituição:

Julgamento:

Assinatura: 
DEDICATÓRIA

Ao querido amigo e mestre Luiz Ernani Fritoli, por ter me apresentado com tanta paixão as letras italianas e a obra do sublime poeta.

À generosidade incansável da Prof ${ }^{a}$ Vilma de Katinszky Barreto de Sousa. 


\section{AGRADECIMENTOS}

Ao $\mathrm{CNPq}$, pela bolsa de estudos concedida na fase final desta pesquisa, de junho a novembro de 2010.

Ao Prof. Dr. Pedro Garcez Ghirardi pela especial atenção e disponibilidade em todas as vezes que foi procurado.

À Prof. ${ }^{a}$ Dr. ${ }^{a}$ Maria Cecilia Casini, pelas leituras, pela amizade, e pela humildade ao compartilhar comigo suas experiências didáticas de leituras dantescas.

Aos colegas de grupo de estudos "Dante, poeta universal na Idade Média e nos tempos modernos", com quem amadureci algumas das idéias aqui expostas.

Aos meus alunos, que, com o seu interesse, me proporcionaram a oportunidade de organizar e apresentar minhas reflexões.

Aos amigos Reinaldo Hening, Mário Domingues, Pedro Heise, Mariane Nadaline e Bruno S. Alexandre pela colaboração direta ao trabalho; e a tantos outros pela colaboração indireta.

Aos queridos Silvia, Edgar, Fernando, Camila e Renato Santomauro, pelo acolhimento e pela maior das nossas riquezas.

À minha irmã Suria, ao Paulo e ao Paulo Henrique, por todo o seu amor e admiração.

Às minhas avós Wanice e Zélia, pela dedicação na minha formação.

Aos meus pais, Roseana e Caio, pelos exemplos, pelos investimentos nos meus estudos e pelo incentivo às letras e à arte.

A Beatriz Santomauro, por ser a minha Beatriz, meu equilíbrio, mãe de todo o nosso amor. 
O mytho é o nada que é o tudo. O mesmo sol que abre os céus É um mytho brilhante e mudo O corpo morto de Deus, Vivo e desnudo.

Este, que aqui aportou, Foi por não ser existindo.

Sem existir nos bastou. Por não ter vindo foi vindo E nos criou.

Assim a lenda se escorre A entrar na realidade. E a fecundá-la decorre. Em baixo, a vida, metade De nada, morre. 


\section{RESUMO}

BRITO, E. F. A insaciável sede de saber na Comédia de Dante. Algumas relações com a incontinência aristotélica. 2010. 108 f. Dissertação (Mestrado) - Faculdade de Filosofia Letras e Ciências Humanas, Universidade de São Paulo, São Paulo, 2010.

A presente pesquisa aproxima a personagem Ciacco, guloso punido na terceira vala do Inferno da Comédia, com a figura da personagem Ulisses, herói grego que atravessou a literatura ocidental antiga até chegar à Idade Média e ser condenado, também no Inferno, pelos seus crimes de fraude. Essa aproximação se realiza pela análise da transgressão de incontinência alimentar, descrita pelo filósofo grego Aristóteles na Ética a Nicômaco, pelo fato dessa transgressão manter uma explícita relação com o pecado do guloso Ciacco, além de ser aplicável à sede de conhecimento que a personagem Ulisses reflete no relato da sua última viagem. Mediante o estudo de obras de Dante Alighieri, como o Convivio e a Comédia, procura-se estabelecer uma conexão entre o desenfreado ato de se nutrir e a falta de moderação na busca pelo conhecimento, sendo essa última aquela que gera a eterna oposição entre ciência e fé, tão importante no contexto religioso no qual a Comédia foi escrita.

Palavras-chave: Dante Alighieri; ética aristotélica; incontinência alimentar; sabedoria; fé 


\begin{abstract}
BRITO, E. F. The insatiable appetite for wisdom in Dante's Comedy. Some relations with Aristotle's intemperance. 2010. 108 f. Dissertation (Master) - Faculdade de Filosofia Letras e Ciências Humanas, Universidade de São Paulo, São Paulo, 2010.

This research compares Ciacco, the greedy character punished in the third ditch in Inferno in Dante's Comedy, with Ulysses, the Greek hero who was brought from Ancient Western Literature to the Middle Ages and condemned - also in Inferno - for his fraud crimes. This comparison is drawn through the analysis of the eating intemperance transgression, described by the Greek philosopher Aristotle in Nicomachean Ethics, since this transgression maintains an explicit relation with Ciacco's greediness and is also applicable to the greed for knowledge which Ulysses reflects in the account of his last trip. Through the study of Dante's works, such as the Convivio and the Comedy, an attempt is made to establish a connection between the unstoppable act of eating and the lack of moderation in the search for knowledge; the latter being what causes the eternal opposition between science and faith, so important in the religious context in which the Comedy was written.
\end{abstract}

Keywords: Dante Alighieri; Aristotelian ethics; eating intemperance; wisdom; faith 


\section{LISTAS DE ABREVIATURAS DAS OBRAS MAIS CITADAS}

Obras de Dante Alighieri

Conv. - Convivio

Comédia:

$$
\begin{aligned}
& \text { Inf. - Inferno } \\
& \text { Purg. - Purgatório } \\
& \text { Par. - Paraíso }
\end{aligned}
$$

DVE - De Vulgari Eloquentia

\section{Obras de Aristóteles}

DA - De Anima

EN - Ética a Nicômaco

\section{Obras de Homero}

Il. - Ilíada

Od. - Odisséia

\section{Obra de Virgílio}

En. - Eneida 


\section{SUMÁRIO}

1 INTRODUÇÃO..................................................................................................... 12

2 A PRESENÇA DA INCONTINÊNCIA NA COMÉDIA ............................................ 25

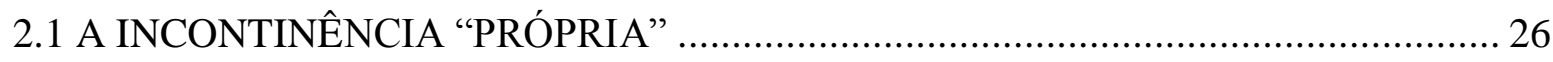

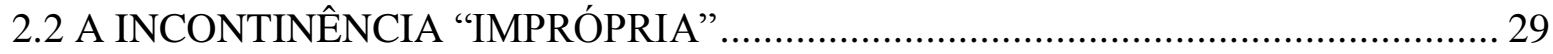

3 CIACCO E O DESEJO EXCESSIVO DE SABOR ........................................... 37

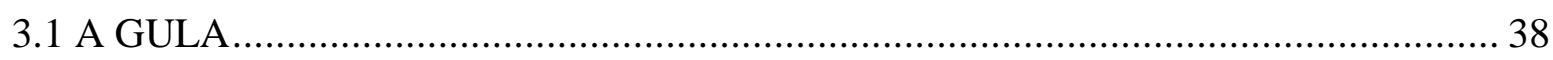

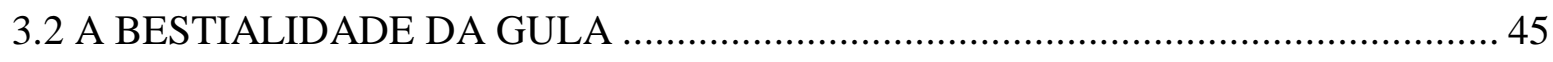

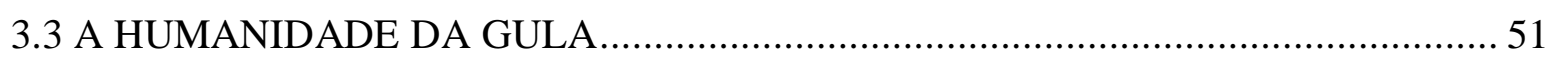

4 ULISSES: BREVE PERCURSO DO HERÓI ................................................................. 54

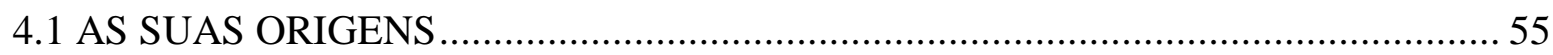

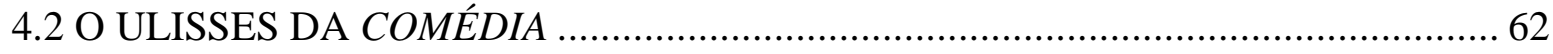

5 ULISSES E O DESEJO EXCESSIVO DE SABER ..............................................66

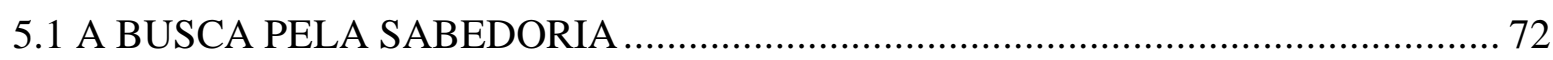

5.2 A EXTRAPOLAÇÃO DA JUSTA MEDIDA INTELECTUAL ................................. 88

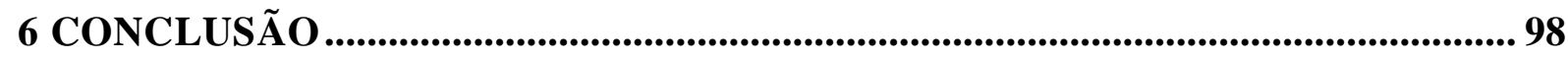

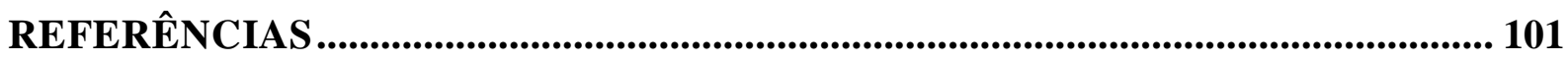




\section{INTRODUÇÃO}

Dante Alighieri foi um sábio. Seu legado literário, político e filosófico confirmam o quanto esse florentino, que viveu entre os séculos XIII e XIV, se deteve nos estudos teóricos e, principalmente, como pôde beneficiar ativamente com o engrandecimento intelectual e espiritual daqueles que o buscaram. Ao que parece, ao longo de vários trechos de sua obra, é exatamente a sabedoria o objetivo maior de sua existência e, por que não, o motivo da sua imensa contribuição escrita. Sem abdicar dos sentimentos, é por meio do conhecimento que o homem pode conquistar a sua completude imaterial, de sorte que em nome desse conhecimento tenham sidas escritas não apenas as obras de Dante, mas a maioria até a atualidade.

Para Aristóteles, filósofo de suma importância para Dante, tudo o que produz a virtude é necessariamente belo (Retórica, 1366b), e para bem discernir a virtude é necessário o conhecimento. Indispensável para Dante, mesmo antes da composição da Comédia, encontra-se ressaltada no Convivio $^{1}$ a naturalidade com que os homens desejam o conhecimento, tido também como um instinto já que todos os seres na natureza buscam a sua integridade e, se é que ela pode ser alcançada, é somente pelo saber. Tal questão é justificada mais uma vez no filósofo, que supõe "o conhecimento entre as coisas belas e valiosas" ( $D A$ 402a1). Dante crê que impulsionados pelo poder da essência humana, que naturalmente deseja o saber, será atingida "a última perfeição da nossa alma" (ultima perfezione della nostra anima. Conv. I I 1) ${ }^{2}$.

Da mesma forma que para o poeta, como para grande parte dos pensadores da antiguidade, "a consciência humana não é o centro onde tem origem a luz da verdade, mas

\footnotetext{
${ }^{1}$ Obra de caráter filosófico, escrita por Dante presumidamente entre os anos de 1304 e 1307 , da qual deixou completos apenas quatro dos quatorze livros intencionados (La vivanda di questo convivio sarà di quattordici maniere ordinata. Conv. I I 14).

${ }^{2}$ Algumas citações da obra de Dante apresentadas neste trabalho, incluindo a totalidade daquelas do Convivio, foram parafraseadas ou traduzidas por mim, seguidas da transcrição do texto original.
} 
apenas um breve espelho que essa luz recolhe e reflete" ${ }^{3}$ (NARDI, 1990, p.136), surge daí a necessidade de se buscar referências que possam servir de base para o conhecimento. Porém, o poeta considera, entre outros motivos, a malícia e a preguiça como fatores que impelem a não almejar o verdadeiro conhecimento e a se encaminhar aos vícios do corpo e da mente, em detrimento do que poderia conduzir à felicidade. É justamente para procurar conhecer melhor esses vícios que assolam os homens que parte o viajante Dante pelos reinos dos mortos na sua narrativa da Comédia.

Sem dúvida a obra de maior fôlego de Dante, a Comédia relata em primeira pessoa a viagem alegórica que o poeta vive como uma potencial alma a ser salva, mas que antes disso fora convidada a conhecer os reinos do além. Baseada em um plano aristotélico-cristão, a ordem física da Comédia evidencia uma obra muito bem dividida e organizada, fazendo crer que a influência dessas correntes de pensamento não se limita à arquitetura do poema. Identifica-se esse tipo de ideal também na sua ordem moral (AUERBACH, 2008, pp. 91-6), que tem por base principalmente a Ética a Nicômaco, do filósofo grego Aristóteles, chegada a Dante por intermédio dos pensadores cristãos como os santos Tomás de Aquino (Par. X-XIV) e Alberto Magno (Par. X 98-9); do averroísta Siger de Brabante (Par. X 136); e de seu professor Brunetto Latini (Inf. XV 85), todos nomes de importância fundamental na formação do poeta e imortalizados na sua obra.

A Comédia é grandiosamente composta por cem Cantos, dividida entre as cantiche ${ }^{4}$ do Inferno (formada pelo Canto I, proêmio de toda a obra, mais outros 33), do Purgatório (33 Cantos) e do Paraíso (33 Cantos); todas perfeitamente unidas entre si não apenas pelo tema como também pela estrutura métrica, que baseia os quase 15 mil versos totais sempre em decassílabos (10 sílabas poéticas) ritmados pelas rimas intercaladas (terza rima) em ABA, BCB,

\footnotetext{
${ }^{3}$ Nos casos onde não for mencionada a tradução, exclusivamente no que se refere à citação indireta dos textos críticos, trata-se de tradução minha.

${ }^{4}$ Preferiu-se manter o original italiano cantica, bem como o seu plural cantiche, pela diferença semântica que o português "cântica" pode provocar, sendo comumente ligado a cantigas e canções jocosas.
} 
$\mathrm{CDC}$, e assim sucessivamente. A primeira cantica narra um mergulho nas profundezas do Mal, para que só a partir daí o poeta viajante possa superá-lo e, com a subida da montanha do paraíso terrestre na segunda cantica, livrar-se dos pecados. Entretanto, não é apenas na terceira cantica da obra - na qual o Bem é alcançado em sua plenitude - que a narrativa é elevada; pelo contrário, a beleza das considerações éticas e poéticas enriquece todas as cantiche, de forma a apresentar ao leitor as dores que são retratadas nas duas primeiras e coroar as considerações éticas e teológicas da terceira. Pois como menciona RosenstockHuessy (2002, p. 49), “quando descobrimos por que determinado estado de coisas é negativo e ruim, começamos a entender a origem do bom"; ou como ressalta Croce (1997, p. 34):

\footnotetext{
"a busca do filósofo acerca da arte precisa percorrer os caminhos do erro para reencontrar os caminhos da verdade, que não são distintos dos primeiros, mas são aqueles mesmos atravessados por um fio que permite dominar o labirinto". 5
}

Para Auerbach (2007, p. 104), em Dante “a beleza poética coincide com a visão da verdade divina e que, portanto, o saber legítimo é tão belo quanto é verdadeira a beleza legítima; e cada verso de seu grande poema é regido por essa estética”. Nesse sentido, mesmo que no começo do poema, a descida ao reino dos condenados, fossem narradas cenas grotescas da natureza humana que remeteriam à imagem de que a beleza não estivesse ali presente, a harmonia entre liberdade, doutrina e criação poética fazem com que o vigor da poesia que Dante compõe atinja suas metas estéticas e filosóficas. E sem dúvida, entre os objetivos principais do poeta está o de trazer à luz do conhecimento as suas crenças: primeiro, em forma de filosofia (per li miseri alcuna cosa ho riservata ${ }^{6}$. Conv. I I 10); depois, com essa filosofia amadurecida e enriquecida pela teologia e pela beleza da poesia, seguindo tão forte,

\footnotetext{
5 Trad. BOSI, 1997.

6 "Para os pobres, tenho algo reservado". Tradução minha.
} 
mas alegórica, recomendação de seu ancestral Cacciaguida ao fazer públicas as suas reflexões (tutta tua vision fa manifesta. ${ }^{7}$ Par. XVII 128).

$\mathrm{Na}$ viagem empreendida pelo poeta peregrino, muitas serão as figuras e personagens históricas que ele encontrará e com quem aprenderá conceitos fundamentais para a sua ascensão racional e espiritual, a começar pelo poeta latino Virgílio, seu guia e seu mestre. Porém, neste estudo pretende-se ler com especial cuidado o encontro que Dante terá com o guloso Ciacco - um concidadão seu, punido no círculo dos incontinentes narrado no Canto VI do Inferno - e com o grego Ulisses ${ }^{8}$, personagem homérica retratada no Canto XXVI, também da cantica infernal, junto aos fraudulentos.

Apesar de penas tão distantes dessas duas almas - seja ideologicamente por se tratarem de pecados diferentes, seja geograficamente no que diz respeito às divisões físicas do Inferno - vê-se que, além de uma simpatia e de uma identificação por parte do poeta na descrição desses encontros, existe nas duas personagens um desejo incontido pela busca de um prazer; prazer tal que inicialmente pode ser visto cingido fortemente a uma necessidade humana. A preocupação aqui será de entender de que forma a busca pelo prazer do alimento, vista em Ciacco, se assemelha à busca por sabedoria, vista em Ulisses, já que nos dois é lida uma extrapolação dos limites humanos em direção àquilo que ambos julgam natural à sua sobrevivência.

Fica evidente a grande complexidade a ser enfrentada quando a proposta é aproveitar ao máximo a riqueza de um poema como a Comédia. Como diz Croce (1948, pp. 67-70), uma leitura fragmentada da obra é insustentável, já que o poema se apresenta como unitário e deve ser encarado com tal. Porém, o próprio crítico reconhece que alguns grupos estruturais como o intelectual-moral e o lírico - convidam a uma análise independentemente, dada a sua

\footnotetext{
7 "Inteira reproduz tua visão." MARTINS, 2006, p. 702. As traduções da Comédia apresentadas em nota de rodapé se referem à obra de Cristiano Martins (Belo Horizonte: Ed. Itatiaia, 2006), salvo quando mencionada outra tradução.

${ }^{8}$ Conforme a grafia usada por Dante (Ulisse), optou-se pela versão latina do nome em detrimento da grega

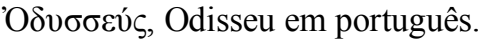


força individual. Com isso, estudar uma obra tão importante para a formação do imaginário ocidental e não atentar para os preceitos éticos abordados ali pelo poeta, seria um tanto quanto imperfeito no que diz respeito à constante busca de parâmetros com a qual um estudioso de literatura deve estar comprometido. Obviamente esses preceitos não são os únicos aspectos relevantes dentro da obra, dadas as suas preocupações estéticas, históricas e políticas. Mas sendo Dante também um homem atento aos rumos da humanidade, é de se reconhecer que no poema exista uma grande preocupação com a busca do engrandecimento da alma.

Pelo fato de a Comédia se tratar de um poema medieval com sólida fundamentação filosófico-teológica, é indispensável que se tenha como referência de pesquisa as concepções que essas correntes de pensamento agregam ao imaginário do poeta Dante. Isso, para que a partir daí se possam enxergar as delimitações e as conexões entre os pecados dos quais o autor se vale para separar os pecadores dentro da cantica do Inferno. Obviamente também na cantica do Purgatório, mas - pelo foco argumentativo - nesta pesquisa serão discutidas apenas questões da primeira cantica, sendo a segunda, bem como a terceira (Paraíso), usadas como recursos para embasar a argumentação central deste estudo.

Para tanto, no Capítulo 2 desta pesquisa, reservado à observação da incontinência, busca-se uma visão pontual das ideias de Aristóteles, visto que a influência do filósofo clássico não é pequena; seja na separação gradual dos erros em decorrência da incontinência, da violência e da fraude, gerando três grandes divisões ${ }^{9}$ no Inferno; seja na discussão dos preceitos éticos, para a qual teremos como base a violação ético-religiosa das personagens da Comédia. Nesse ponto, bem como no Capitulo 3, será direcionada a atenção para o exame das virtudes e seus equivalentes

\footnotetext{
${ }^{9}$ Em Inf. XI 79-83 o poeta justifica a arquitetura infernal com base em Aristóteles, que em EN 1145a17 discorre sobre a gravidade dos vícios.
} 
contrários feito no tratado aristotélico Ética a Nicômaco. Com base nessa obra, o poeta fundamenta-se na classificação do filósofo acerca das disposições morais a serem evitadas pelo homem, que no mundo cristão são entendidas como pecados, mas que derivam de uma concepção anterior ao próprio filósofo chamada de hybris, brevemente definida como "limites impostos aos homens pelos deuses gregos que habitavam o Olimpo" (JAEGER, 2001, p. 195).

Na carta a Cangrande della Scala, um dos benfeitores de Dante no período de exílio, e a quem é dedicado o Paraíso, tem-se entre os motivos que levaram à escrita da Comédia o de "afastar aqueles que vivem neste mundo do estado de sofrimento e conduzi-los a um estado de felicidade" ${ }^{10}$ (Ep. XIII 39). Isso, baseando suas razões e reflexões na Ética, disciplina filosófica que procura seus alicerces nos fundamentos do agir, sobretudo na ação.

Com isso, é importante sustentar que as personagens que Dante escolhe para ilustrar seus exemplos éticos estão sempre em função de um conceito moral, mas a tentativa que se faz, neste estudo, de entender as considerações do autor não almeja julgar tais personagens, e sim refletir sobre os conceitos éticos de Aristóteles que até aqui chegaram por meio da poesia de Dante. Para além da carga religiosa que o termo pecado possa denotar, esta pesquisa busca pensar e compreender em que medida essa concepção se agrega ao imaginário do autor e de como ele procurou ilustrá-lo dentro de seu poema. Pois como diz Auerbach (2008, p. 86), a vontade de ordem que faz com que Dante encontre as suas bases teóricas na filosofia clássica de Aristóteles, ou na escolástica de São Tomás de Aquino, é a mesma que o conduz à criação poética, podendo ele ali transcender a razão da qual tanto depende a filosofia de seus mestres.

Muitas são as perspectivas a partir da quais podem lidas as obras de Dante, sejam elas políticas, históricas, filosóficas e literárias, entre outras. Se levadas em consideração as perspectivas históricas e políticas, é necessário ter como ponto de referência a importância que o homem Dante teve para a sua cidade, Florença, e ao seu

10 "[...] removere viventes in hac vita de statu miserie et perducere ad statum felicitatis." Tradução minha. Apesar de citada por vários importantes comentadores de Dante, como Sapegno (1993, p. VII) ou Chiavacci Leonardi (Inf., 2005, p. 4), ainda se questiona a autenticidade dessa epístola. 
tempo, fim do século XIII, início do XIV. Nesse período, sua terra natal passava por um conturbado momento político, sendo a presença de Dante de crucial valor, fato que o levou ao exílio no ano de 1302, por decreto de desafetos políticos, alguns retratados no poema (PETROCCHI, 2004, p. 85). Contudo, a abordagem que se pretende com este estudo, está muito mais voltada a entender as questões que levaram o poeta a fazer certas escolhas filosóficas, principalmente pela análise de algumas de suas referências literárias, três obras em especial: a Eneida, a Ética a Nicômaco e a Bíblia.

Como não poderia deixar de ser em se tratando de literatura, a intertextualidade da obra de Dante passa pelos sábios filósofos da antiguidade e pelos "pais da igreja", que ensinaram ao poeta o caminho a ser trilhado. Da mesma forma, participam desse referencial os heróis que outrora serviam de exemplo para os homens da Grécia Antiga, aqueles que fizeram parte de uma cultura que tinha em Homero o principal educador. O desenvolvimento da mencionada intertextualidade adquire uma importância especial na literatura italiana, em particular, já desde a sua expressão em língua latina. Duas civilizações que conviveram de maneira tão intensa, no declínio de uma e na ascensão de outra, os gregos e os latinos não poderiam deixar de se encontrar também na literatura.

No universo ficcional presenteado à humanidade pelo poeta Virgílio, sua célebre Eneida, a viagem intertextual se manifesta na tomada de Tróia pelos aqueus da Ilíada de Homero, obrigando a Enéias partir em busca de uma terra prometida por sua mãe, a deusa Afrodite, com seu velho e mortal pai Anquises sobre os ombros e tomando o pequeno Ascânio pelas mãos (En. II 663-803) ${ }^{11}$. Partida que geraria o início de uma nova cultura e

\footnotetext{
${ }^{11}$ Essa imagem também nos passa G. L. Bernini com a sua esplêndida escultura Pietà (Galleria Borghese, Roma) baseada na Eneida, de Virgílio. Bernini representa o peso do velho Anquises sobre os ombros do herói Enéias como a bagagem da civilidade antiga dos troianos trazida ao ocidente, assim como no menino Ascânio a sua semente germinada e a promessa de um futuro em terras novas.
} 
civilização na península itálica (la porta onde uscì de' Romani il gentil seme. ${ }^{12}$ Inf. XXVI 5960) e depois do mundo ocidental, com o advento das conquistas romanas.

Resulta-se a Eneida como um importante referencial para Dante. Escrita no primeiro século antes de Cristo, tal obra é citada diretamente não menos que duas vezes logo no primeiro Canto da Comédia, como na apresentação da sombra que aparece para Dante: "Poeta fui, e cantai di quel giusto / figliuol d'Anchise che venne di Troia"13 (Inf. I 73-4), e assim percebe-se ser Virgílio tal sombra; e quando o poeta se refere à Itália pela qual morreram Camila, Eurialo, Turso e Niso (per cui morì la vergine Cammilla / Eurialo e Turno e Niso di ferute" ${ }^{14}$ Inf. I 107-8), todos personagens cantados pelo mestre e, naquele momento, futuro guia de Dante na viagem pelos mundos do além.

Porém, é com o verso "Miserere di me', gridai a lui"15 (Inf. I 65, grifo do autor) que temos uma referência indireta à obra latina, que ao mesmo tempo reflete uma diretíssima influência do poeta romano sobre Dante. Trata-se de uma expressão de súplica exatamente igual àquela usada por Enéias, herói da narrativa virgiliana, quando esse viajava pelo hades (En. VI 117). Além disso, a própria escolha do poeta Virgílio como o guia ao longo das cantiche do Inferno e do Purgatório reflete um profundo respeito pelo poeta latino, que será substituído pela sua grande musa Beatriz apenas na entrada do paraíso terrestre.

Ao longo da descida pelos círculos do Inferno, muitos e diferentes são os pecadores citados, separados de acordo com a gravidade dos pecados. Mas é somente quando os poetas estão saindo do sexto círculo que temos explicitado pelo guia Virgílio a justificativa de tal separação. Com base nos escritos do filósofo Aristóteles sobre "le

\footnotetext{
12 "Foi de Roma a semente germinando". Ibid., p. 268.

13 "Poeta fui e celebrei o filho justo / de Anquises, que a estas plagas veio um dia". Ibid., p. 81.

14 "Por quem Euríalo, a cândida Camila, / Turno e Niso findaram na agonia". Ibid., p. 82.

15 “' 'Piedade!' eu lhe gritei, 'ouve os meus ais'”. Ibid., p. 81.
} 
tre disposizion che 'l ciel non vole" ${ }^{\text {16 }}$ (Inf. XI 81) - ou seja, a incontinência, a violência e a fraude ( $E N$ 1145a 17) -, apresenta-se diante de nós uma imagem de como são divididos os condenados pelos círculos do Inferno, salientando a grande contribuição da Ética a Nicômaco nessa divisão, referida pelo guia de Dante como "la tua Etica" (Inf. XI 80). Segundo Virgílio, os incontinentes se encontram ao longo do segundo ao sexto círculo; os violentos, ao longo do sétimo; e os fraudulentos, ao longo do oitavo e do nono círculo, mais perto de Lúcifer pela gravidade de seus pecados. O comentador da Comédia Daniele Mattalia (1975, p. 21) ressalta que Virgílio (simbolizando a poesia) - junto a Aristóteles (a filosofia) e a Ulisses (a ação) - representa a antiguidade pagã nos seus limites, mas também no alto valor do seu complexo magistério, "como sujeito contemplado não sem a angústia humana de uma teológica e impenetrável tragédia, onde essa última é instrumento de salvação, mas que se encontra excluída dela".

Nesse sentido, o campo de pesquisa que procura traçar paralelos entre a obra de Dante e do filósofo grego Aristóteles, de quem o poeta incorpora o método investigativo de prolongar até os últimos constituintes do objeto de estudo (DVE II X 1), é extremamente fértil. Nos Cantos iniciais da Comédia, fica explícita a valorização de Dante dos seus referenciais helênicos, quando invoca as musas e o seu "alto engenho" (Inf. II 7-9) para que o ajudem a lembrar de tudo aquilo que presenciou na sua viagem pelos círculos da fossa infernal. Em seguida, ao eleger Homero o poeta soberano (Inf. IV 88) e Aristóteles ${ }^{17}$, ladeado por Sócrates e Platão, o mestre de todos os sábios que habitam a antecâmara do Inferno, a quem todos do "Nobre Castelo" conferem honras ${ }^{18}$.

\footnotetext{
16 “Os três pontos que o céu jamais tolera". Ibid., p. 160.

${ }^{17}$ Desde Boccaccio, é de concordância geral por parte da crítica que, apesar de não ser citado seu nome, trata-se de Aristóteles o mais sábio sentado entre os sábios. Cf. BOCCACCIO, 1918, pp. 59-60.

${ }^{18}$ Por mais que se afirme que Dante não conhecera a língua grega bem como a sua literatura, é indiscutível que esses referenciais chegaram até ele por intermédio de outros poetas latinos como Ovídio, Estácio, Sêneca e Virgílio, essenciais para o amadurecimento lírico do poeta. Cf. CHIAVACCI LEONARDI, 2005, Inf., p. 782.
} 
A presença de Aristóteles na Comédia é notada desde os primeiros versos, quando o narrador fala de uma das fases da vida que o filósofo já tinha descrito, quando o poeta se dá conta de ter atingido o ponto intermediário de sua existência, seus 35 anos.

Nel mezzo del cammin di nosta vita mi ritrovai per una selva oscura, che la diritta via era smarrita. ${ }^{19}$ (Inf. I 1-3)

Como resume De Libera (2004, p. 356), apesar de uma inicial proibição eclesiástica à leitura de Aristóteles, o século de Dante é testemunha do nascimento de uma tradição que traduz e comenta o filósofo. Daí vieram as primeiras grandes considerações feitas pelos santos Alberto Magno e Tomás de Aquino e que foram posteriormente incorporadas tanto pelos dogmas da Igreja Católica como por Dante, que o define várias vezes no seu tratado filosófico como o maior de todos os sábios da humana sabedoria: glorioso filosofo al quale la natura più aperse li suoi segreti (Conv. III V 7); maestro de l'umana ragione (Conv. IV II 16); Aristotile è maestro e duca de la ragione umana (Conv. IV VI 8); maestro de li filosofi (Conv. IV VIII 15$)^{20}$.

Segundo a comentadora da Comédia Chiavacci Leonardi (2005, Inf. p. 7), a noção de que o homem tem como ideal tempo de percurso na terra, a idade de 70 anos é considerada como uma teoria aristotélica, recuperada por Santo Alberto Magno e São Tomás de Aquino. Nesse sentido, como escreveu Nardi (1990, p.144), “quando os escolásticos tiveram contato com a filosofia de Aristóteles procuraram imediatamente uma forma de cristianizá-la".

Entretanto, essa referência também está no livro dos Salmos: "Setenta anos é o tempo de nossa vida" (BÍBLIA, 2003. Sl 90 [89] 10), sendo a Bíblia outro livro base

19 "A meio do caminho desta vida / achei-me a errar por uma selva escura, / longe da boa vida, então perdida." Ibid., p. 76.

20 "Glorioso filósofo a quem a natureza mais revelou os seus segredos; Mestre da razão humana; Aristóteles é mestre e guia da razão humana; Mestre dos filósofos.” Tradução minha. 
para as discussões aqui apresentadas. Como em outras partes de sua trajetória de escritor $^{21}$, o poeta assume nesse trecho inicial da Comédia o texto bíblico como fonte de suas reflexões históricas e cita o Gênesis, primeiro dos livros do Antigo Testamento, como a origem de tudo (Inf. XI 107). Porém, sabendo-se que a viagem do poeta não se resume aos reinos infernais e entendendo que a Comédia deve ser compreendida como um todo, não somente com uma leitura independente de cada uma das três cantiche, que se tem na Bíblia um modelo de suma importância para Dante. É possível verificar a referência à viagem de São Paulo ao que ele chama de "terceiro céu" (BÍBLIA, 2003. 2 Cor 12 2); é nela que o poeta obscurecido pelos seus erros se ampara quando se vê diante de uma viagem parecida com a de outras duas importantes figuras literárias: Io non Enea, io non Paulo sono ${ }^{22}$ (Inf. II 32).

É também observando o texto bíblico que este estudo se apoiará, no Capítulo 5, em uma das imagens fundamentais para toda a concepção de pecado da tradição cristã: a desobediência de Eva. A primeira de todas as mulheres cometera tal pecado frente a uma proibição do Deus do Antigo Testamento em se alimentar do fruto proibido (BÍBLIA, 2003. Ge 3 5). A imagem do duplo erro de Eva será essencial na compreensão do texto dantesco, que aqui se faz pensando o pecado de Ciacco em direção à gula, e ao pecado de Ulisses, em direção à extrapolação dos limites de seu conhecimento. Isso porque o pecado original é lido como uma desobediência de Eva ao ingerir do fruto proibido, o que pode caracterizar uma espécie de erro de intemperança corporal pela não-necessidade desse fruto, mas também pela falta de freio intelectual pelo significado que esse fruto carrega: o conhecimento do Bem e do Mal. Há de se reconhecer que o pecado inicial de Eva pode ser lido de muitas maneiras; por exemplo, pelo pecado da soberba, no qual possuir o conhecimento do Bem e do Mal é uma tentativa de igualar-se ao Criador, como fez o anjo-caído Lúcifer (BÍBLIA, 2003. Is 14 12),

\footnotetext{
${ }^{21}$ Cf. Conv. IV, v, 16 e DVE I, IV, 1.

22 "Não sou Enéias, não sou Paulo". Ibid., p. 88.
} 
segundo interpretação dos "padres da igreja" ${ }^{23}$. Contudo, para o foco deste trabalho, se estabelece a perspectiva da incontinência na análise das citadas ações.

É pelo exame da Ética a Nicômaco, e de alguns de seus comentadores, que está sendo dada particular atenção ao conceito aristotélico de incontinência no interior do poema e, para tanto, será analisado um possível caráter incontinente das duas personagens do Inferno. O guloso Ciacco, retratado no Capítulo 3, servirá como base para se pensar a questão ortodoxa da incontinência - chamada também de intemperança alimentar, já que está relacionada diretamente com o pecado da gula, ou falta de temperança frente aos prazeres do alimento. Quanto ao fraudulento Ulisses - analisado no Capítulo 4, quando se atentará para a sua trajetória ao longo de algumas obras da literatura ocidental - será exigido que a questão da incontinência seja estudada um pouco mais a fundo e que seja observada, principalmente, a maneira como o poeta estabelece a relação entre o alimentar-se e o instruir-se ao longo do Convivio e da Comédia, observação que ocupará o início do Capítulo 5. A insaciável sede de Ulisses certamente não foi em direção ao sabor, mas ao saber.

Ao longo do Capítulo 5, para que a proposta de análise se realize, será preciso que aquilo que convencionalmente se classifica como incontinência, ou ausência de limite, ultrapasse a relação evidente com a intemperança dos prazeres do corpo e se projete também em outros aspectos existentes dentro do leque de vontades humanas; leiam-se essas não apenas como físicas, mas também como aspirações intelectuais. Tais vontades tão naturais à essência humana como as próprias necessidades corpóreas e vistas como indispensáveis para a aproximação do homem à sua perfeição dentro do imaginário dantesco, bem como no daqueles que influenciaram o poeta. Como observa Nardi (1990, p.137), a expressão escolástica "primeira natureza" - da qual se vale Dante logo nas primeiras linhas do Convivio para justificar a origem da vontade de conhecimento - é referência direta a

\footnotetext{
${ }^{23}$ Cf. BÍBLIA, 2003, p. 1276.
} 
Aristóteles (Metafísica 1015a 13-15). Vontade traduzida pelo poeta como "ardor", ou seja, o amor intenso e concupiscente que tanto Ulisses manifestou na sua vontade de conhecer o mundo (Inf. XXVI 90-99), quanto o próprio poeta confessou em vias de ser saciado no fim de sua viagem e busca pelo saber (Par. XXXIII 46-8).

Para somar-se à compreensão filosófico-teológica de Dante, é preciso estar presente o entendimento de pecado como o concebe a tradição cristã, ou seja, a partir dos textos de seus pensadores, também chamados de "doutores da igreja", como os já mencionados Santo Alberto Magno e São Tomás de Aquino - importantes comentadores de Aristóteles, aos quais Dante seguramente teve acesso e fundamentais veículos na difusão da obra do filósofo grego (DE MATTEIS, 1996, p. 372). No âmbito prevalentemente teológico vale ressaltar Santo Agostinho - pertencente a outro grupo denominado "padres da igreja" -, que considera o pecado "uma fraqueza moral, ou um ato insuficiente de vontade, uma escolha corrupta" (Confissões VII III 5).

Tomando por base alguns conceitos aristotélicos fundamentais para Dante e considerando o percurso filosófico-teológico que esses conceitos percorreram até chegar ao poeta, bem como a análise de estudiosos que pensaram o pecado de Ciacco e o complexo pecado de Ulisses, acredita-se que alguns objetivos no sentido de compreender um pouco mais a natureza humana serão discutidos e, com sorte, alcançados. 


\section{A PRESENÇA DA INCONTINÊNCIA NA COMÉDIA}

Propõe-se neste capítulo observar como o vício da incontinência se apresenta pelos círculos infernais. Vale lembrar que esse vício é também ilustrado em algumas figuras do Purgatório; mas como o foco da discussão aqui apresentada tem como objetivo apenas as duas personagens do Inferno, Ciacco e Ulisses, a segunda e até mesmo a terceira cantica servirão apenas para reforçar a leitura que se faz das personagens citadas.

De acordo com Auerbach (2008, p. 91), na organização do grande poema da Comédia são criados e fundidos três sistemas que se correspondem na ordem divina: o sistema físico, o ético e o histórico-político. Desse modo, mesmo sabendo que essas três ordens são apenas parcialmente separáveis, por fazerem parte de uma obra perfeitamente harmônica e coesa, é pensando no sistema ético que será apresentada uma tentativa de entender a incontinência. Como lembra o comentador Natalino Sapegno, (1955-57, Inf. I Nota) ${ }^{24}$, a energia do propósito ético provê inspiração às inseparáveis poesia, estrutura e técnica da grande obraprima de Dante. É justamente nesse sistema ético que o poeta procura pensar os princípios que motivam, distorcem ou orientam o comportamento humano que ele reflete nas suas personagens.

Para que esse olhar sobre a incontinência se realize, será levada em consideração a atenta leitura de alguns comentadores que tanto se empenharam em compreender a obra do poeta, como já se pôde notar. Comentadores que fazem da crítica dantesca uma das mais vastas e férteis, em se tratando de fortuna literária, e que nesta pesquisa foram escolhidos não só por critérios editoriais que os tornam mais acessíveis; também por critérios temporais, principalmente no que diz respeito aos contemporâneos do poeta, de modo que a sua língua e as suas referências se tornem mais claras. Mas será no texto tido pela maioria dos

\footnotetext{
${ }^{24}$ As citações de comentadores de Dante sem citação de número de página se referem a consultas feitas no banco de dados digital do Dartmouth Dante Project. Cf. Referências Bibliográficas.
} 
comentadores da obra de Dante como fundamental para as considerações filosóficas do poeta, a Ética a Nicômaco, que se apoiará a discussão da questão ética.

\subsection{A INCONTINÊNCIA "PRÓPRIA"}

Seguindo a organização física dos círculos infernais, a incontinência é o primeiro vício a ser demonstrado pelas personagens castigadas, já que antes de ser apresentado a essas personagens o leitor sabia apenas da condição das grandes almas da antiguidade, que se encontram tranquilas na antecâmara do Inferno; sabia também do sofrimento dos ignavos, mas de tão fracos diante da escolha pelo bem ou pelo mal, esses não foram dignos nem mesmo de atravessar o Aqueronte, rio que os separa dos verdadeiros pecadores.

A incontinência propriamente dita faz-se presente a partir do círculo dos luxuriosos, com a enumeração de diversas figuras históricas que extrapolaram os limites do apetite sexual. Esses réprobos são mostrados por meio de figuras de almas que foram reconhecidamente desmedidas no ato libidinoso; entre outras, encontram-se ali a alma do herói grego Aquiles e também as de Helena de Tróia e Cleópatra, duas mulheres que provocaram discórdias históricas entre seus companheiros pela falta de freio diante do apetite pelo sexo. Tais almas são condenadas a sofrer perdidamente, conduzidas e molestadas por golpes de vento que não as deixam esquecer o quanto foram passíveis aos impulsos da carne.

É no primeiro círculo da incontinência que começam os sons incômodos produzidos pelos gritos dos condenados (le dolenti note. Inf. V 25) que Dante terá de suportar ao longo de sua viagem. Para criar essa atmosfera de dor, o leitor é gradualmente introduzido a essa cena infernal pela menção ao barulho que lá se produz; logo em seguida, pela menção ao sofrimento dos condenados, ao serem maltratados pelas batidas causadas pelo vento. Mas, ao 
contrário de uma tempestade natural, a tempestade que ali se vê não tem fim, como na entrada do Inferno já estava preanunciado: per me si va ne l'etterno dolore ${ }^{25}$ (Inf. III 2).

La bufera infernal, che mai non resta, mena li spirti con la sua rapina; voltando e percotendo li molesta. ${ }^{26}$ (Inf. V, 31-3)

Na parte final do Canto, apresenta-se o diálogo que Dante mantém com a condenada Francesca da Rimini, um dos passos mais lidos e comentados de toda a Comédia, quando o poeta faz transparecer uma de suas versões do amor cortês ${ }^{27}$, deixando na sombra o pecado e realçando o que de mais delicado e afetuoso havia na pecadora. Para De Sanctis, (1993, p. 47), "Francesca não é o divino, mas o humano e o terrestre, um ser frágil e apaixonado", que narra a sua desafortunada morte tomando o amor como motivo central. Ainda segundo o crítico, "justamente porque o amor é representado como uma força estranha à alma e incontrastável, o que aqui existe é debilidade, não depravação”.

Amor, ch'al cor gentil ratto s'apprende, prese costui de la bella persona che mi fu tolta; e 'l modo ancor m'offende. Amor, ch'a nullo amato amar perdona, mi prese del costui piacer sì forte, che, come vedi, ancor non m'abbandona. Amor condusse noi ad una morte. ${ }^{28}$ (Inf. V 100-6)

\footnotetext{
25 "Por mim se vai à sempiterna dor." Ibid., p. 94.

26 "A borrasca infernal, que nunca assenta, / as almas vai mantendo em correria; / e voltando, e batendo, as atormenta." Ibid., p. 110.

${ }^{27}$ Como outros representantes da poesia que Dante chama de dolce stil nuovo (Purg. XXIV, 57), no episódio citado o poeta propõe uma interpretação do cor gentil. Outros nomes importantes para esse tema foram alguns de seus contemporâneos como Andrea Cappellano (De Amore) e Guido Guinizzelli (Al cor gentil rempaira sempre amore). Cf. CAMPOS, 1998, p. 183.

28 "Amor, que a alma gentil no imo surpreende, / prendeu-o à forma que era minha e viva; / e foi tomada em modo que inda ofende. / Amor, que a amado algum de amar não priva, / uniu-me a ele também, tão doce e forte, / que, como vês, ainda aqui se aviva. / Amor nos conduziu à mesma morte.” Ibid., p. 115.
} 
Segundo Ciotti (1996, p. 417), os condenados por crime de incontinência dispõem de uma humanidade altamente significativa, que os separa dos outros réprobos do Inferno seguindo uma ordem moral tanto de Dante como de seus cânones filosóficos - e que os deixa longe de Lúcifer, preso no fundo da câmara infernal. É nesse episódio que se inicia o tom compassivo do qual o poeta se servirá para conduzir os seus e os nossos sentimentos ao tratar de certos incontinentes nos próximos cantos, principalmente do guloso Ciacco, fato a ser tratado principalmente no Capítulo 3, e que depois também se refletirá quando do encontro com a alma de Ulisses, no Canto XXVI do Inferno, fato a ser tratado a partir do Capítulo 4 desta pesquisa. Seria essa presença de humanidade o motivo de certos punidos merecerem compaixão por parte do narrador? O próprio poeta expõe no fim do diálogo:

\section{Mentre che l'uno spirto questo disse, \\ l'altro piangëa; sì che di pietade \\ io venni men così com'io morisse. \\ E caddi come corpo morto cade. ${ }^{29}$ \\ (Inf. V 139-42, grifo meu)}

Como ressalta Fubini (1963, p. 4), “o sentimento do poeta diante dos seus personagens não termina com o julgamento que faz deles como teólogo". Nesse sentido, segue-se o Canto VI e a personagem lá encontrada, Ciacco, contemporâneo de Dante e, segundo Jacopo della Lana (1324-28, Inf. VI 38-42), "muito corrupto no predileto vício da gula". Nos dois casos, tanto se pensadas as personagens luxuriosas quanto as gulosas, Ciotti (1996, p. 416) caracteriza tal manifestação de incontinência como "própria", pela falta de autocontrole estar enraizada nas necessidades naturais do corpo; principalmente por terem como objeto os prazeres corpóreos derivados das paixões congênitas dos atos alimentares e sexuais. Em Aristóteles, identificam-se as virtudes de um homem que possui autocontrole sendo louvadas, enquanto a falta de regra é necessariamente apresentada como um vício:

\footnotetext{
29 "Em quanto a história triste um tinha dito, / Tanto carpia o outro, que eu, absorto / em piedade, senti leal conflito, / E tombei, como tomba corpo morto." Trad. XAVIER PINHEIRO, 1958, p. 33, grifo meu.
} 
Ora, as seguintes opiniões são sustentadas: que o autocontrole e a firmeza são disposições boas e louváveis e que o desregramento e a indolência são [disposições] más e censuráveis; (...) que o indivíduo sem autocontrole (desregrado) faz coisas de que está ciente serem más sob a influência das paixões, ao passo que o homem autocontrolado, ciente de que seus desejos são maus, recusa-se a seguir-los devido à razão (...). ${ }^{30}(E N 1145$ b 8-15)

Ciacco, o incontinente frente aos prazeres do corpo, será discutido mais detalhadamente no próximo capítulo pelo fato dessa personagem estar envolvida com a questão da alimentação. Tal questão, de grande importância para a reflexão deste trabalho, merece ser analisada com mais calma por conter na sua essência o que se distingue como a necessidade que tem o corpo de se nutrir, seja do 'pão dos homens', seja do 'pão dos anjos' ${ }^{\text {'31 }}$.

\subsection{A INCONTINÊNCIA "IMPRÓPRIA"}

Mais adiante, na descida dos círculos infernais, são apresentados pelo poeta outros tipos de pecados manifestados pela incontinência, imaginada por Ciotti (1996, p. 416) como “impróprios" por não serem naturais ao homem e estarem relacionadas "ao ganho, à riqueza material, à honra e à ira". Também, segundo Chiavacci Leonardi (2005, Inf., p. 205), seriam essas vaidades e bestialidades mais graves em relação à incontinência "própria”, pois ofendem profundamente a dignidade do homem por não fazerem parte de sua natureza.

No círculo dos avaros e pródigos, aqueles que não tiveram comedimento ao dar ou ao conservar riquezas, o leitor não é apresentado a nenhuma personagem em particular, mas é mencionada a excessiva quantidade de réprobos que padecem desse mal. Como nos explica o guia Virgílio, a deformação moral da alma desses condenados foi transmitida à forma física

\footnotetext{
${ }^{30}$ Trad. BINI, 2007, p. 202.

${ }^{31}$ pan de li angeli (Conv. I, I, 7 / Par. II, 11), visto como a sabedoria divina e celestial da qual os anjos gozam eternamente no céu (CHIAVACCI LEONARDI, 2005, Par., p. 53).
} 
como eles agora lá se acham punidos e nenhum deles é digno de ser reconhecido pelo poeta Dante por estarem desprovidos de qualquer tipo de luminosidade que os fizesse reconhecer (MATTALIA, 1975, pp. 159-60).

\author{
E io: "Maestro, tra questi cotali \\ dovre' io ben riconoscere alcuni \\ che furo immondi di cotesti mali". \\ Ed elli a me: "Vano pensiero aduni: \\ la sconoscente vita che i fé sozzi, \\ ad ogne conoscenza or li fa bruni.," 32 \\ (Inf. VII 49-54)
}

Nesse círculo, o maior vício a ser condenado é o excesso em relação ao afeto material, e não ao desprendimento; basta lembrar a loba do início do poema (Inf. I 49), representada entre os três grandes obstáculos àquele que buscava o caminho da salvação e tida pelos antigos comentadores de Dante como símbolo do desejo desenfreado. Além disso, o desprendimento se conduzido a um fim mais nobre pode engrandecer a alma; ressalte-se o exemplo também citado por Dante de São Francisco de Assis, o santo que deixou tudo por amor a Deus (Par. XI).

Finalmente, os últimos incontinentes a se acharem punidos nessa primeira parte ${ }^{33}$ do Inferno são aqueles que em vida se deixaram levar pelos vícios da ira e da acídia. Os primeiros encontram-se nas águas rasas e pantanosas do rio Estige, o segundo rio infernal que precede a muralha de Dite. Os outros condenados estão imersos nas mesmas águas (Inf. VIII), ocultados por elas assim como em vida foram obscurecidos pela preguiça ao conduzirem-se ao bem. Para Chiavacci Leonardi (2005, Inf., p. 250), não existe dúvida de que Dante represente nesse círculo um pecado particularmente grave e perigoso. Segundo a autora, na ira está contida uma arrogância cheia de orgulho, atribuída àquela pessoa que se acha mais

\footnotetext{
32 “ 'Mestre', insisti, 'quem sabe nos dois lados / eu veja alguns do meu conhecimento, / por estes vícios torpes dominados?' / Voltou-se e disse: 'É vão teu pensamento: / a tara que os nivela, deprimente, / os imuniza ao reconhecimento" ". Ibid., p. 128.

${ }^{33}$ Representada pelos círculos que estão fora dos muros da cidade de Dite e correspondente aos Cantos V ao VIII.
} 
importante que outras, desencadeando, com isso, o ódio e terríveis ressentimentos. Nesse sentido, ao testemunhar o episódio de Filippo Argenti ${ }^{34}$ nota-se que é a primeira vez que os poetas peregrinos se dirigem a um condenado com palavras duras, fato que irá se repetir várias vezes na viagem pelo mundo do além.

\footnotetext{
E io a lui: "Con piangere e con lutto, spirito maladetto, ti rimani; ch' $i$ ' ti conosco, ancor sie lordo tutto". Allor distese al legno ambo le mani; per che 'l maestro accorto lo sospinse, dicendo: "Via costà con li altri cani!". 35 (Inf. VIII 37-42).
}

O tom é ríspido e duro, fazendo transparecer que aquele mínimo de compaixão demonstrado pelos primeiros incontinentes já foi completamente deixado de lado; e fazendo com que a força que conduz a referência ao punido seja de total desprezo, assim como a memória que dele restou no mundo dos vivos (Inf. VIII 46-8). E é com esse desprezo aos condenados que Dante interrompe bruscamente a narrativa e volta a sua atenção ao que virá em seguida: a entrada de Dite.

\footnotetext{
Lo buon maestro disse: "Omai, figliuolo, s'appressa la città c' ha nome Dite, coi gravi cittadin, col grande stuolo". ${ }^{36}$ (Inf. VIII 67-9, grifo meu)
}

Tanto o leitor quanto o próprio poeta Dante são conduzidos pelos próximos versos por certa insegurança, "tristeza e solenidade" (CHIAVACCI LEONARDI, 2005, Inf., p. 239) do guia Virgílio, que sabe que as suas palavras não têm o mesmo poder com os demônios

\footnotetext{
${ }^{34}$ Florentino da segunda metade do século XIII e de quem o comportamento soberbo e irascível era famoso. Foi retratado também na novela IX, 8 do Decamerão, de Giovanni Boccaccio (1349-1351).

35 “'No eterno pranto, na ânsia mais profunda', / bradei-lhe 'hás de quedar-te, condenado: / reconheci-te sob a crosta imunda!' / Ao lenho as duas mãos lançou, irado, mas o meu mestre logo o afugentou, gritando: 'Põe-te ao largo, cão danado!' " Ibid., p. 136.

36 “ 'Filho', disse-me o guia, 'a hora é chegada / de em Dite entrar, metrópole maldita, / com tristes cidadãos e força armada.'” Ibid., p. 137.
} 
cristãos que guardam as muralhas de Dite como tiveram com os guardiões dos outros círculos infernais. Como esclarece Mattalia (1975, p. 180), Virgílio entende que a habitual fórmula de persuasão que costumava abrir passagem para os peregrinos no Inferno não vai funcionar com tais demônios. A razão simbolizada por Virgílio está longe de ser suficiente para que os poetas continuem na sua viagem, e será muito mais difícil persuadir tais demônios do que era com aqueles da sua antiga fé pagã, como Minós (Inf. V), Cérbero (Inf. VI) e Plutão (Inf. VII); será preciso que um “anjo do Senhor” (Inf. IX 86 et seq.) venha do reino dos céus e abra as portas de um novo mundo, onde só a malícia e a bestialidade imperam.

Dentro de Dite, como grifado na citação anterior, são punidos pecados mais graves do que a incontinência dos primeiros círculos. Mas quando o próprio Dante mostra-se curioso de entender o porquê dessa separação, é Virgílio quem toma a palavra e evoca o filósofo quase onipresente na obra de Dante. Ao se falar da incontinência, é possível enlevar-se pelo antigo guia às referências filosóficas indispensáveis do poeta e, com isso, surge em Aristóteles a fonte quando são esclarecidas questões tão profundas da alma humana.

\author{
Non ti rimembra di quelle parole \\ con le quai la tua Etica pertratta \\ le tre disposizion che 'l ciel non vole, \\ incontenenza, malizia e la matta \\ bestialitade? e come incontenenza \\ men Dio offende e men biasimo accatta? ${ }^{37}$ \\ (Inf. XI 79-84, grifo meu)
}

A ética à qual Virgílio faz referência é tida desde os primeiros comentadores do poema dantesco como a Ética a Nicômaco, apresentada nesse trecho como la tua Etica (v. 80). Segundo Ciotti (1996, p. 415), “a construção moral do poema é modelada a partir do exemplo ilustre da Eneida, mas reflete uma influência especial na ética aristotélica", temperada e moderada pelos principais comentadores de sua época, entre eles, principalmente, Santo

\footnotetext{
37 "Não te lembras da forma clara e vera / pela qual tua Ética apresenta / os três pontos que o céu jamais tolera / a incontinência, a astúcia, e inda a nojenta / bestialidade? E que à incontinência, / mais leve que é, pena mais leve assenta?" Ibid., p. 160, grifo meu.
} 
Alberto Magno de Colônia, São Tomás de Aquino e Siger de Brabante, todos eles retratados no Canto X do Paraíso como símbolos de harmonia entre sabedoria e fé. Apesar de apresentarem diferentes leituras da obra de Aristóteles, os três comentadores citados são de grande importância para a cultura filosófica de Dante, que também para De Matteis (1996, p. 372) está embasada na filosofia aristotélica.

As três disposições ou conformações com o mal citadas por Virgílio e comentadas por Aristóteles no Livro VII da Ética a Nicômaco (EN 1145a 17), são a incontinência (acrasia), a malícia (kakia) e a bestialidade (theriótes), das quais o homem deve manter distância. De acordo com L'Ottimo Commento (1338, Inf. XI 79-90), incontinência é quando o desejo do homem se encontra pervertido, mas a sua razão preservada. Isso se manifesta quando o homem é o verdadeiro juiz de suas ações, sabendo o que se deve e o que não se deve fazer. Porém, por corrupção do desejo, abandona a virtude e segue o vício. Por essa falta de corrupção moral, mas sim do desejo, pode-se entender a compaixão sentida por Dante quando do diálogo com Francesca da Rimini e com Ciacco, representantes daquela que Mattalia (1975, p. 247) chama de "incontinência simples" 38 e que já vinha defina como "incontinência própria" por Ciotti (1996, p. 417).

A malícia, ainda para L'Ottimo Commento (1338, Inf. XI 79-90), seria quando o desejo se encontra pervertido a ponto de alterar a razão e o intelecto, fazendo, com o tempo, com que o homem ceda conscientemente ao desejo corrupto. Assim, o desejo começa a ser considerado malicioso por eleger perversamente seus objetos, julgando serem justas tais eleições. Para ele, a bestialidade seria quando o desejo se corrompe tanto que ultrapassa e opera além dos termos e usos do homem, fazendo obras animalescas contra a sua natureza e os seus costumes. O autor exemplifica com o comportamento de alguns homens da

\footnotetext{
${ }^{38}$ Luxúria e gula, mais leve em relação à 'incontinência aggiunta': avareza e ira.
} 
Cumania $^{39}$, que comiam carne humana, esquartejavam mulheres grávidas e viviam sem leis.

Desse modo, ele resume:

Por aquilo que é dito, mostra-se que a incontinência é somente a corrupção do apetite, estando a razão prática intocada. A malícia é a perversidade do apetite e da razão prática. Bestialidade é quando não somente estão pervertidos tanto o apetite quanto a razão prática, mas ainda se age contra a natureza com ações animalescas, assim como fez Tideu a Menalipo. E, desse modo, Deus é menos ofendido pela incontinência do que pela malícia ou pela bestialidade, e pela bestialidade mais do que pela malícia; por essa razão, os incontinentes luxuriosos, gulosos e outros de quem já se tratou (...) são punidos do lado de fora da cidade de Dite e com menor tormento, porque ofenderam menos a divina Justiça do que os maliciosos e os bestiais. ${ }^{40}$

Surge com isso uma graduação na gravidade das culpas, fazendo com que exista essa separação vertical dos círculos do Inferno. A incontinência é menos grave que a malícia e a bestialidade, sendo as manifestações incontinentes da luxúria e a gula menos graves que as outras por estarem relacionadas a bens necessários como o da reprodução e o da alimentação. Nesse sentido, os outros vícios dentro do leque da incontinência, como a avareza e a prodigalidade, estão relacionados à vontade desmedida de bens não estritamente necessários e não próprios de todos os homens e, portanto, podem ser considerados mais graves em relação àqueles necessários.

Não se tem claro que tipo de culpa representaria exatamente a bestialidade no reino infernal dantesco, o que ainda deixa abertura para muita discussão. Segundo a crítica Chiavacci Leonardi, se a malícia comporta a violência e a fraude, parece não sobrar espaço para a bestialidade dentro do Inferno, como concluíram muitos comentadores antes dela, já que mesmo em Aristóteles seria essa uma culpa desumana e rara. Mas a maioria dos

\footnotetext{
${ }^{39}$ Região da Europa nos arredores do rio Danúbio, atual Hungria.

${ }^{40}$ Tradução minha de: "Per quello che è detto appare che Incontinentia è solamente corruptione de l'appetito, rimanendo la ragione pratica diritta. Malitia è perversitade de l'appetito et della ragione pratica. Bestialitate è quando non solamente si perverte l'appetito et la ragione pratica, ma ancora s'opera contra natura per bestiali operatione, sì come fece Tideo a Menalippa. Et così Dio è meno offeso per la incontinentia che per la malitia o per la bestialitate, et per la bestialitade più che per la malitia; perciò seguita et conchiude che quelli incontinenti luxuriosi et gulosi et altri de quali è tractato di sopra (...) sono puniti di fuori della cittade di Dyte et con minore tormento, perché meno offesoro la divina Iustitia, che li malitiosi et bestiali." L'OTTIMO COMMENTO (1338, Inferno 11.79-90).
} 
comentadores antigos, entre os quais Pietro di Dante (1340, apud CHIAVACCI LEONARDI, 2005, Inf., p. 352), considera que o poeta indicasse com essa classificação as três grandes subdivisões do Inferno - incontinência, violência e fraude - fazendo coincidir a matta bestialitade (Inf. XI 82-3) com a violência.

Contudo, se pensada a figura evidente de bestialidade representada no Minotauro (Inf. XII), guardião do círculo dos violentos, bem como a presença dos tiranos e dos sodomitas entre os ali punidos (exemplos também para Aristóteles), pode-se pensar que exista uma espécie de adaptação não rara aos textos de Dante nas ideias de seus cânones. Como ressalta Petrocchi (1989, p. 72), o esquema aristotélico foi usado pelo poeta com bastante liberdade; não apenas para inserir aquelas culpas que lhe foram estabelecidas posteriormente pelo cristianismo, mas também para criar um complexo de situações totalmente originais. Isso, já que para o filósofo grego seria a bestialidade a mais grave das culpas e, para o poeta, identifica-se que esse conceito é aplicado à malícia da qual se valeram todos os punidos no profundo Malebolge.

No que se refere às bases para definir a incontinência na Comédia, pode-se ver que dessa vez o termo assume para Dante o mesmo valor que já se notava em Aristóteles (EN 1118a 1-7), estando ligado aos prazeres do corpo e em contraposição à virtude da moderação. A incontinência é definida pelo poeta assim como já o tivera sido pelo filósofo: como um "vício provocado pelos costumes e pelas experiências" humanas; um apego aos prazeres provocados pela fruição de um objeto (vizii consuetudinarii, alli quali non ha colpa la complessione ma la consuetudine, sì come la intemperanza, e massimamente del vino. Conv. III VIII 17). É de se entender que, para Dante, a incontinência ofenda Deus e a consciência moral menos que a malícia porque não provoca o mal a outros indivíduos; ou como diz Pietrobono (1956, p. 122), “falta ao incontinente a vontade de fazer mal a outros com força ou com fraude". Com isso, não são maus por vontade deliberada, mas por paixão ou impulso 
rebelde ao freio da razão. Seria esse o motivo por estarem fora da cidade de Dite, a cidade maligna do reino infernal.

Que se passe, então, adiante para a análise mais detalhada de um dos incontinentes retratados no poema dantesco, o glutão Ciacco do VI canto do Inferno. Essa análise servirá para amadurecer os conceitos que depois poderão ser aplicados a outra personagem que, tradicionalmente, não possui nenhuma relação direta com a incontinência senão pela tentativa de leitura que mais adiante será proposta dela: o herói Ulisses e o seu incomensurável desejo de saber $^{41}$.

${ }^{41}$ É interessante notar que na língua italiana, assim como no português clássico já em desuso (surgido entre 1562 e 1575 segundo o dicionário eletrônico HOUAISS 1.0), o verbo sapere, ou "saber", pode ser denotado como "ter o sabor de", como o próprio Dante indica em "Tu proverai sì come sa di sale lo pane altrui" (Par. XVII 58-9, grifo meu). 


\section{CIACCO E O DESEJO EXCESSIVO DE SABOR}

A convite das três mulheres que no paraíso olham por ele (Inf. II 124-5), Dante parte em uma viagem como escolhido a conhecer o reino dos mortos. No ante-inferno, o viajante presencia a angústia dos ignavos, aqueles que foram fracos e indecisos quando vivos e que ali são condenados a correr atrás de um símbolo (Inf. III 34-69). Dentro do Nobre Castelo, ele se admira com a magnanimidade que as grandes almas da antiguidade ainda preservam, apesar de não poderem ter sido salvas (Inf. IV 67-142). No entanto, conforme apresentado no capítulo anterior, é ao entrar no círculo dos luxuriosos que o peregrino Dante começa a ver a dor dos condenados ao reino de Lúcifer.

No primeiro círculo da incontinência (Inf. V), entre algumas figuras históricas como Cleópatra e Helena de Tróia, o poeta se compadece do sofrimento dos famosos amantes Paolo e Francesca da Rimini. Logo adiante, no círculo dos gulosos, o cenário muda; e com ele os condenados. Após a entrada do círculo guardada por Cérbero, cão de três cabeças, manifesta-se Ciacco, o florentino que reconhece Dante pela sua familiar linguagem toscana. Chega-se ao Canto VI do Inferno, onde são narradas as primeiras experiências do poeta Dante com o pecado da gula.

Segundo Mattalia (1975, pp. 139-40), a personagem a reconhecer o peregrino Dante, quando ele caminha entre os punidos pelo vício de comer e beber em excesso, é identificada por alguns antigos comentadores do poeta como sendo o rimador florentino Ciacco dell'Anguillaia, figura pouco conhecida na história, mas bastante identificada na tradição literária não só pela representação de Dante, mas também pelo retrato que Giovanni Boccaccio fez dela em uma de suas novelas do Decamerão: um glutão como jamais havia existido (Ciacco, uomo ghiottissimo quanto alcun altro fosse giammai. Decam. IX 8). Ainda segundo o comentador, Ciacco provavelmente era uma pessoa bastante 
conhecida da sociedade florentina do século XIII, que vivia uma vida entre a "parasita" e a "mundana"; era considerado um bom orador, um refinado apreciador da boa comida e um grande animador dos "salões" e das refeições de gala.

Contudo, é tradição na crítica dantesca que se leia nesse Canto uma conotação política pelas previsões que o guloso Ciacco faz a respeito da cidade de Florença, deixando, muitas vezes, que o pecado ali retratado fique de lado. E para a discussão deste capítulo - pensando também nos objetivos maiores deste trabalho, que é pensar a incontinência de outra personagem -, o pecado da gula será levado em consideração em maior proporção do que a conotação política que ali se possa ler. Mas o fato de o peregrino Dante ter escolhido essa e não outra personagem para falar de sua cidade natal não será ignorado, já que esse papel certamente não seria dado a um réprobo por quem o poeta nutrisse algum tipo de repugnância.

\subsection{A GULA}

Definido pela cristandade como apetite desordenado de comida e bebida e uma degeneração do instinto que leva o homem a se alimentar de acordo com as suas necessidades de existência, a gula encaixa-se na classificação de pecado por incontinência, uma vez que representa um não-domínio das vontades humanas, as quais são induzidas pela própria natureza do homem (MORSTABILINI, 1951, tomo VI, p. 903.). Os gulosos, segundo os parâmetros éticos cristãos, pecam por não fazerem uso do excedente de comida que ingerem, extrapolando os limites naturais do corpo.

Dando continuidade à análise que entende o conceito de incontinência em Dante como fruto da influência de Aristóteles, cabe retomar a Ética a Nicômaco, em que o filósofo 
discorre sobre os valores dos princípios éticos e morais que regem a conduta do homem e na qual procura ordenar as virtudes e contrapô-las aos vícios que as arruínam. No terceiro livro da obra, após tratar de virtudes particulares como a coragem, o filósofo volta a sua atenção à análise da temperança, estabelecendo os parâmetros a partir dos quais se pode classificar um intemperante, ou seja, pelos extremos opostos à "justa medida":

(...) O apetite por alimento é natural, visto que todos desejam alimento sólido ou líquido e, por vezes, ambos, quando experimentam a necessidade deles; e também a relações sexuais, como diz Homero, quando jovens e vigorosos. (...) No caso dos desejos naturais, portanto, poucos incorrem em erro e, quando o fazem, somente naquele do excesso; pois empanturrar-se de comida e bebida é exceder a quantidade natural dos mesmos, uma vez que o desejo natural corresponde apenas a satisfazer a própria necessidade. ${ }^{42}(E N$ 1118b 8-18)

Apesar de o filósofo considerar que um intemperante deseja tudo aquilo que lhe é prazeroso ou aquilo que o é de modo particular ( $E N$ 1119a 1-5), é nítido nesse passo que Aristóteles se refere aos prazeres relativos ao comer e beber em excesso. Isso, por julgar que outros prazeres corporais, como o de ouvir música ou de admirar um belo quadro, estejam mais relacionados à mente do que diretamente ao corpo, sendo a comida e o sexo desejos do corpo. Aristóteles dividiu os vícios em três grandes grupos, de uma maneira mais abrangente, considerando tais erros contrapostos às virtudes equivalentes: a deficiência moral, a incontinência e a bestialidade ${ }^{43}$ (EN 1145a 17). Seria essa a mesma tríplice macrodivisão da qual se vale Dante no Inferno para separar e ilustrar a condenação dos diferentes pecadores no reino do além, como explicitado na apresentação que o guia Virgílio faz dos círculos infernais (Inf. XI) e também apresentado no capítulo anterior.

Caminharam também nesse sentido os primeiros textos acerca dos sete pecados capitais, principalmente os de Gregório Magno que, em seu tratado sobre os vícios humanos,

\footnotetext{
${ }^{42}$ Trad. BINI, 2007, pp. 113-4.

43 Trad. CURY, 2001, p. 257.
} 
elencou uma espécie de ordem baseada na intensidade da culpa (Moralia XXXI 45); a mesma ordem que segue Dante no Inferno, e principalmente no Purgatório, para ilustrar a distância em que os pecadores se encontram ora do senhor do mal, ora de Deus. Seguindo uma intensidade decrescente em relação à intencionalidade e, portanto, à culpa, seriam os vícios: a soberba, a inveja, a ira, a acídia, a avareza, a gula e a luxúria. Para a desmedida alimentar - a gula -, é adotado o conceito de intemperança, ou seja, fraqueza em se conter diante daquilo que seria indispensável à natureza dos homens, nesse caso especificamente o instinto de sobrevivência. Sempre com base em Aristóteles (EN 1145b 15-6), pode-se entender que a intemperança alimentar é uma das manifestações da incontinência, a falta de autocontrole em um sentido mais amplo.

Distingue-se na Enciclopédia Católica que todas as vezes que alguém peca, está violando livremente a própria natureza, o que permite enxergar o significado da distinção largamente usada entre pecado "contra a natureza" e pecado "segundo a natureza". Acreditase que o primeiro seja mais grave que o segundo porque exige uma presença maior da livre decisão humana (VANNICELLI, 1951. Tomo IX, pp. 1016-1024). Com isso, para aquilo que a tradição cristã romana acredita, a conduta do homem deve consistir fundamentalmente no exercer a própria natureza e, por isso, o pecado da gula pode ser definido como um ato livre contra a própria natureza.

No entanto, é de se observar que a hierarquização dos pecados encontrada nos preceitos católicos é de uma relevância muito pequena para aquilo que São Tomás de Aquino já pregava, uma vez que é considerado o fato de todos os pecados possuírem aspectos característicos de outros (De Malo XIV 1-4); como a gula, que pelo excesso de comida pode invocar a preguiça e, pelo excesso de bebida, pode tornar uma pessoa violenta. Veja-se o exemplo bíblico de Noé, que depois de beber vinho em quantidade, não se deu conta de sua 
nudez e foi repreendido pelo filho Cam, pai de Canaã. Num ímpeto de ira e vergonha, em decorrência de um ato guloso, Noé amaldiçoou a linhagem do filho:

\author{
"Maldito seja Canaã! \\ Que ele seja, para seus irmãos, \\ O último dos escravos!" \\ (BÍBLIA, 2003. Gn 9 20-25)
}

O fato de os preceitos cristãos aceitarem uma diferença entre a gravidade dos pecados, dividindo-os em pecados "segundo a natureza" e aqueles "contra a natureza", é uma clara referência aos textos aristotélicos, nos quais encontram-se definidos os vícios por intemperança como um prolongamento dos instintos do homem e os de bestialidade como não comuns à natureza humana, porque seus impulsos se resolvem com a luz do conhecimento, esse necessário à virtude moral e inerente à nossa natureza. É discutida abertamente pelo filósofo a necessidade de que, desde a criança, sejam instituídos hábitos em conformidade com a reta razão para que não haja afastamento da virtude (EN 1103b 23-36).

Por intermédio das anotações de seus pensadores, sob a perspectiva do aspecto teológico do pecado, tem-se na teologia cristã que a conduta humana é também uma vontade de Deus, estreitando desse modo a ideia de livre arbítrio como dignidade da alma difundida por Santo Agostinho, na qual todo homem possui a capacidade de escolher entre o que considera bom ou mau (VANNICELLI, 1951. Tomo IX, p.1017). Ainda, segundo Santo Agostinho (Confissões VII III 7), o mal moral é um ato insuficiente de vontade, do qual para estar livre - e, portanto, bem usar o livre arbítrio - é indispensável a intervenção divina.

São Tomás de Aquino (De Malo XIV, 1-4) também discorre sobre a dificuldade de dispor organizadamente o prazer segundo a razão, principalmente em se tratando daqueles prazeres que ele chama de "companheiros de nossa vida", precisamente os de comer e beber. Fala-se, contudo, na perda da agilidade da inteligência quando se come e bebe em quantidade 
exagerada. Da mesma forma, o historiador Jacques Le Goff cita a indignação do religioso cartuxo Guilherme de Conches ao se referir à alimentação eclesiástica:

O maior número de nossos bispos revolve o universo para encontrar alfaiates ou cozinheiros capazes de preparar requintados molhos apimentados (...). Quanto àqueles que se entregam ao saber, fogem deles como leprosos (...). (Séc. XII, Apud LE GOFF, 2005, p. 358)

Santo Agostinho (Confissões X XXXI 47), quando se lamentou por sua fraqueza diante da comida, sabia que nem sempre é claro quando se atinge o ponto da saciedade e se pode abandonar aquilo que se está ingerindo. Segundo ele, para que a prática do exagero não ocorra, devemos nos espelhar nas nossas sensações físicas, porque o excesso de comida não se aplica a nenhuma função. Come-se demasiadamente apenas pela falta de autocontrole, não dando nenhum fim a toda a quantidade consumida além do necessário que não o acúmulo no próprio corpo. E dentro das concepções éticas usadas como base para a presente pesquisa tanto as filosóficas, baseadas em Aristóteles, como as teológicas, baseadas em alguns dos principais pensadores da religião católica - o exagero não deve ser cometido; deve-se escolher sempre a justa medida.

Nesse sentido, gula como ingestão exagerada de alimento é passível de condenação sob a perspectiva ética de Dante, já que os gulosos em questão comeram em demasia apenas para saciar um prazer fora de controle. Foi com esse impulso passional pela comida que agiu Ciacco, guloso punido dentro do terceiro círculo do Inferno dantesco.

\footnotetext{
"Voi cittadini mi chiamaste Ciacco: per la dannosa colpa della gola, come tu vedi, a la pioggia mi fiacco.

E io anima trista non son sola, ché tutte queste a simil pena stanno per simil colpa". E più non fé parola. ${ }^{44}$ (Inf. VI 52-7)
}

\footnotetext{
44،، 'Ciacco por todos lá era eu chamado: / pelo vício da gula, miserando, / nesta chuva, que vês, vou mergulhado. / Mas não sou eu sozinho aqui penando; / sob um castigo igual todos estão, / por igual culpa.'E olhou-me, silenciado.” Ibid., pp. 122-3.
} 
A gula, desde quando analisada pelos pensadores citados, foi sempre considerada como um crime individual por fazer mal somente àquele que a comete e pelo pecado estar em “venerar o próprio ventre como a um Deus" (PROSE, 2004, p. 17). No entanto, em sua condenação é de se crer que o poeta tenha se baseado no princípio oposto ${ }^{45}$, vista a maneira coletiva como cumprem suas penas os culpados pela gula no Inferno. Como bem observa Chiavacci Leonardi (2005, Inf., p. 174), está presente nesse pecador a consciência ética pela qual ele reconhece a sua culpa e julga correta a própria condenação. Nesse sentido, aqui é indicada uma estreita ligação com a noção aristotélica de incontinente como aquele que ignora os seus próprios valores em favor de um prazer momentâneo que julga importante.

$\mathrm{O}$ aspecto individual é fundamental nesse pecado, mas entende-se que a moralidade coletiva pode efetivamente ser prejudicada com os excessos de um guloso. "Não se deve esquecer as componentes simbólicas e ideológicas da alimentação: a comunhão, a frequência dos jejuns, a condenação da gula (...)", afirma Montanari (2002, p. 38). Com isso, define-se também o vício da gula como um desvio moral, ou seja, pelo qual o conjunto das regras comuns tidas como verdadeiras por um determinado grupo é molestado pelo comportamento de um cidadão. Considera-se que outras pessoas podem vir a ser prejudicadas com a falta de alimento gerada pelo exagero de alguns.

Aqui se retoma a definição do pecado da gula por meio da separação entre os vícios humanos feita por Aristóteles e, posteriormente, adotada pela filosofia católica a partir de reflexões de alguns de seus maiores pensadores como São Tomás de Aquino e Santo Alberto Magno. Aplica-se o rótulo da incontinência, adotado pelo filósofo grego, ao tipo de gula pelo qual são punidas as almas que se encontram nesse terceiro círculo, porque essas tais almas não conseguiram se afastar dos bens e dos prazeres mundanos obtidos por causa da comida e

\footnotetext{
${ }^{45}$ O princípio das penas na Comédia baseia-se na lei do contrapasso, critério de punição a partir do qual toda pena é aplicada com similaridade ou distanciamento das transgressões terrenas de maneira a relembrar constantemente os espíritos das faltas ou excessos praticados em vida. Cf. ARMOUR, 2000.
} 
da bebida e, portanto, não souberam se conter diante daquilo que foi designado aos seus corpos, em vida, como um meio de sobrevivência.

Deve-se considerar que no período medieval, dentro do qual se compreende a Comédia, o ato de comer exageradamente estava relacionado a uma atitude nobre. Nobre não no sentido de louvável, mas sim de estar diretamente ligado ao comportamento de aristocratas, no qual o apetite denotava força e vigor. Montanari (2002, p. 38) menciona o episódio em que o Duque de Espoleto foi rejeitado como rei dos francos pelo seu fraco apetite: "não é digno de reinar sobre nós aquele que se contenta com uma pequena refeição", diziam eles. No intento de demonstrar firmeza e vigor, muitas vezes a ética cristã não era considerada, mas sim contrariada.

Não que pelo fato de tais atitudes estarem relacionadas aos nobres fossem elas mais do que simplesmente aceitas pela sociedade em geral. Pelo contrário, por se tratar de um período no qual as técnicas de agricultura ainda não geravam enormes resultados, e a caça restrita, era normal que o alimento fosse escasso à mesa do cidadão medieval comum. Sem contar que a abundância de comida era comum somente aos ricos, muito provavelmente invejada pelos cidadãos que não tinham acesso a ela. Existe, por exemplo, o relato de um fabliau medieval que descreve o país imaginário chamado "Cocanha", no qual o alimento nunca acaba e para o qual as pessoas não precisam fazer nenhum esforço senão o de esticar o braço e alcançar o que se deseja ${ }^{46}$. Isso leva a crer que a quantidade de comida presente à mesa da população medieval em geral era bem menor do que a idealizada, fazendo com que fossem sonhadas quantidades ilimitadas.

Neste ponto, se encaixa o guloso do VI círculo do Inferno, que em vida aproveitou abusivamente dos prazeres da comida; em contrapartida, sofreu com o julgamento de seus concidadãos. Esse fato é constatado pelo apelido recebido, Ciacco, que em língua florentina

\footnotetext{
${ }^{46}$ Cf. FRANCO Jr., 1998, p. 26.
} 
de então (meados do século XIII) significava "porco" e aparece na Comédia como único meio pelo qual tal personagem foi conhecida, visto que seu nome foi ocultado por Dante apesar de especulações que o ligam ao poeta florentino Ciacco dell'Anguillara.

\subsection{A BESTIALIDADE DA GULA}

Pensando na condenação do guloso, somos ligados diretamente à figura do porco e a partir das ideias difundidas pelos bestiários medievais - é de se notar que o valor simbólico desse animal para o homem há muito está em discussão. Segundo Le Goff (2005, p. 110), a sensibilidade zoológica da Idade Média se nutriu da "ignorância científica", pois a zoologia dessa época teve como base a Physiologus, obra alexandrina do Séc. II que "dissolve a ciência na poesia fabulosa e nas lições moralizantes", dando origem a uma série de criações simbólicas a partir do comportamento dos animais. No que se refere especificamente ao porco, também a Bíblia menciona várias vezes o caráter ambíguo de sua alimentação, considerando-o imundo e impuro já desde o Antigo Testamento:

"Iahweh falou a Moisés e a Aarão, e disse-lhes: 'Falai aos israelitas e dizeilhes: Estes são os animais que podereis comer, dentre todos os animais terrestres: Todo animal que tem o casco fendido, partido em duas unhas, e que rumina, podereis comê-lo. (...) tereis como impuro o porco porque, apesar de ter o casco fendido, partido em duas unhas, não rumina. Não comereis da carne deles nem tocareis o seu cadáver, e vós os tereis como impuros." (BÍBLIA, 2003. Lv 11 1-8)

Não comerás nada que seja abominável. (...) Quanto ao porco, que tem o casco fendido mas não rumina, vós o considerareis impuro. Não comereis de sua carne e nem tocarei em seus cadáveres. (BÍBLIA, 2003. Dt 14 1-8)

Apesar de estar de acordo com as classificações alimentares impostas pelo livro dos hebreus e dos cristãos, na qual os quadrúpedes devem ter o casco fendido em duas unhas para 
que sejam considerados puros, o porco não é necessariamente herbívoro e não rumina, ou seja, não mastiga de novo a erva que já engoliu. Pode-se considerar o fato de que esse animal também se distingue dos seus semelhantes por comer todo o tipo de alimento, inclusive carne, o que pode ter contribuído para que os homens o vissem como guloso.

Considerando que a doutrina católica não condena o consumo da carne suína - como a hebraica ou mesmo a islâmica -, enxergar a personagem Ciacco e os outros glutões punidos dentro do terceiro círculo do Inferno como porcos por terem eles comido avidamente a carne desse animal, ou por terem eles comido com o apetite e a voracidade desse animal, seria compreensível dentro do imaginário cristão ocidental que está sendo estudado ${ }^{47}$. Isso pode ter origem já no episódio homérico quando os companheiros de Ulisses são transformados em porcos pela feiticeira Circe logo após se fartarem de seu banquete.

Ela os levou para dentro e of'receu-lhes cadeiras e tronos, e misturou-lhes, depois, louro mel, queijo e branca farinha em vinho Prâmnio; à bebida, assim feita, em seguida mistura droga funesta, que logo da pátria os fizesse esquecidos. Tendo-lhes dado a mistura, e depois que eles todos beberam, com uma vara os tocou e, sem mais, os meteu na pocilga. Tinham de porcos, realmente, a cabeça, o grunhido, a figura e as cerdas grossas; mas ainda a consciência anterior conservavam. ${ }^{48}$ (Od. X 233-40)

Para a punição desses gulosos, Dante ilustrou com uma chuva incessante, pesada e fria a pena à qual estariam sujeitas aquelas almas apegadas aos prazeres terrenos; chuva essa que apodrece a terra na qual devem chafurdar essas almas pecadoras. É interessante observar a aproximação com a terra que faz o poeta para punir os incontinentes: com base na lei do contrapasso como uma forma para punir os culpados pela gula, nesse momento, o prazer

\footnotetext{
${ }^{47}$ É de se considerar que além do imaginário ocidental, a ideia de incontinência alimentar também possa estar associada à figura do porco na tradição oriental. Ver o filme em forma de animação A Viagem de Chihiro, no qual os pais da protagonista Chihiro são transformados em porcos por seu apetite voraz. A Viagem de Chihiro (Spirited Away). Dir. Hayao Miyazaki. Japão, 2001.

${ }^{48}$ Trad. NUNES, 1996, p. 140.
} 
obtido pelos sentidos do olfato e do paladar é provocado e contraposto ao nojo e à repugnância causados pelo horror da terra podre que a chuva remove e ajuda a deteriorar.

\author{
Io sono al terzo cerchio, de la piova \\ etterna, maledetta, fredda e greve; \\ regola e qualità mai non l'è nova. \\ Grandine grossa, acqua tinta e neve \\ per l'aere tenebroso si riversa; \\ pute la terra che questo riceve. ${ }^{49}$ \\ (Inf. VI 7-12)
}

A imagem de almas que pagam pelos seus pecados rolando e penando na lama é bastante associável à imagem de porcos que se revolvem e se atolam dentro dos chiqueiros. A partir disso, é de se atentar à natureza do comportamento dos porcos e de como os homens a interpretam há muito tempo: como um animal sujo e guloso, digno de receber como alimento sempre o que há de menos nobre pela sua impureza e gula; o qual está sempre disposto a comer e se fartar com aquilo que o homem rejeita. Identifica-se esse fato em mais um exemplo bíblico, desta vez no Novo Testamento na Segunda Epístola de São Pedro: “O cão voltou a seu próprio vômito, e: “A porca lavada voltou a revolver-se no lamaçal'” (BÍBLIA, 2003. 2 Pd 22 , grifo do texto original).

É explorada pela citação bíblica uma ideia de retorno. Retorno que pode ser entendido como para a essência do animal; para onde o conduz o instinto. Portanto, considerada a semelhança da natureza dos dois animais citados, o porco e o cão, seria natural que uma porca depois de limpa voltasse à sua essência "imunda"; e que um cão, depois de expelir aquilo que seu organismo rejeitou, comesse novamente o expelido, dada a sua natureza gulosa.

Com isso, percebe-se que o porco não é o único animal que faz parte do imaginário coletivo como um exemplo de guloso; também o cão, como Cérbero, o guardião do círculo

49 "Era o terceiro Círculo, a que fria, / maldita e eterna chuva circunscreve, / a qual a regra alguma obedecia. / Granizo grosso, água viscosa e neve / soltavam-se do espaço teneroso, / apodrecendo a terra frouxa e leve." Ibid., p. 120. 
dos gulosos. Trata-se de um cão mitológico que desde a tradição grega guardava a entrada do hades, o reino dos mortos; um animal feroz de três cabeças caninas e cauda de serpente (GUIMARÃES, 2002, p. 103), que se assemelha - sob o olhar crítico do narrador Dante - a um verme, pelo lugar onde se encontra; uma besta que uiva e atormenta com as três bocas, para o desespero dos pecadores que se encontram nesse círculo.

Cerbero, fiera crudele e diversa,
con tre gole caninamente latra
sovra la gente che quivi è sommersa. ${ }^{50}$
(Inf. VI 13-15)

Dante não é o primeiro a fazer referência a essa fera mitológica que representa um animal guloso, Cérbero aparece também em outras obras da literatura clássica como na Eneida. É explícita e claramente assumida pelo poeta a influência sofrida na leitura de Virgílio, porque, assim como no poema clássico latino, na Comédia existe uma viagem aos infernos, ali chamados Tártaro, mas com o mesmo valor simbólico negativo para as duas tradições dos dois poetas - a latina pagã e a cristã.

A partir da viagem feita por Enéias, herói da narrativa virgiliana, Dante recolheu experiências a serem narradas na sua viagem, agora como narrador/herói e não apenas como leitor. A exemplo de sua passagem junto a Virgílio - sob o encargo de guia propriamente dito e não mais somente como modelo literário - pelo cão guardião do círculo dos gulosos. Assim como na Eneida, na Comédia existe uma tentativa por parte de Cérbero de impedir que os viajantes Virgílio e Dante atravessem o terceiro círculo. Nesse ponto, da mesma maneira que conta Enéias com a virgem sacerdotisa Sibila para enganar a besta com um bolo soporífero, Dante conta com a experiência do poeta Virgílio, que na função de protetor lança um monte de terra podre para instigar a gula e a atenção de Cérbero.

\footnotetext{
50 "Cérbero, dúplice anima, furioso, / às três goelas, ladrava sobre a gente / ali submersa, como um cão raivoso." Ibid., p. 120.
} 
E 'l duca mio distese le sue spanne, prese la terra, e con piene le pugna la gittò dentro a le bramose canne. Qual è quel cane ch'abbaiando agogna, e si racqueta poi che 'l pasto morde, ché solo a divorarlo intende e pugna cotai si feccer quelle facce lorde de lo demoio Cerbero, che 'ntrona l'anime sì, ch'esser vorreber sorde. ${ }^{51}$ (Inf. VI 25-33)

Logo na entrada da cova, estendido no solo se achava Cérbero, abertas as três desconformes gargantas, aos uivos. Vendo a Sibila encresparem-se as cobras dos seus três pescoços, presto uma torta lhe atira de mel, de antemão preparada com dormideira. De pronto ele a apara nas goelas ardentes, antes de ao solo tocar e, os tendões afrouxando do dorso, a corpulência espantosa estirou no chão duro da cova. ${ }^{52}$ (Eneida VI 417-423)

Em ambas as narrativas, os viajantes obtiveram êxito nos seus propósitos, ou seja, despertaram os instintos da fera gulosa e foram capazes de passar por ela durante o seu momento de distração e sedução provocado pelo "alimento" recebido. No primeiro exemplo, tem-se a imagem de um animal cego que se deixa enganar, mais pelo gesto da ação de Virgílio do que propriamente pelo sabor daquilo que estava recebendo; no segundo, existe uma premeditação por parte de Sibila, que prepara uma iguaria que o faz dormir.

Baseado em sensações cotidianas, é de se perceber que, após nos alimentarmos, temos um momento de lentidão que tem a sua duração determinada pela quantidade de alimento consumido. Com isso, pode-se projetar no comportamento do Cérbero dantesco uma atitude semelhante à que teria um homem comum depois de ingerir uma quantidade de alimento além da necessária à sua sobrevivência, ou seja, um momento de perda de sua sagacidade e de sua esperteza.

\footnotetext{
51 "Meu mestre, então, as mãos em conchas assentes / de terra encheu, e a foi arremessando / bem no interior das goelas repelentes. / Como o cão, que o alimento reclamando / ladra, e quando lhe é dado cessa o ruído, / somente em devorá-lo se ocupando / - assim quedou-se o monstro enfurecido, / cujas bocas, troando, aos condenados / faziam desejar perder o ouvido." Ibid., p. 121.

${ }^{52}$ Trad. NUNES, 1981, p. 123.
} 
É interessante notar que em várias outras circunstâncias do poema é por intermédio das palavras do guia Virgílio que os poetas obtêm a permissão de seguir adiante com a sua viagem pelo reino dos mortos, seja no momento em que os dois se deparam com o barqueiro Caronte (vuolsi cosi colà dove si puote / ciò che si vuole, e più non dimandare ${ }^{53}$. Inf. III 95 6), seja quando os poetas chegam à praia do purgatório e são autorizados por Catão a seguir adiante (donna scese del ciel, per li cui prieghi de la mia compagnia costui sovvenni ${ }^{54}$. Purg. I 53-4 ). Porém, na passagem em que os dois poetas se defrontam com a besta gulosa é por uma artimanha de Virgílio que eles conseguem passar, e não mais invocando o poder que lhes foi concedido pelas três mulheres que habitam o reino dos céus (Inf. II 124). Por meio do engano provocado, os viajantes conseguem uma abertura na vigilância de Cérbero, provocando na fera um momento de satisfação, que vem acompanhado de um instante de gozo e um retardamento, que nesse caso permitiu a passagem dos poetas pelo círculo dos gulosos.

Sobre tal retardamento, fez menção São Tomás de Aquino quando enumerou, em seus escritos sobre os sete pecados capitais, as "cinco filhas" que o excesso do prazer desregulado no comer e no beber pode gerar, sendo o mais grave deles o "embotamento da inteligência” (De Malo XIV 1-4). Nesse sentido, a razão é a mais prejudicada, pois é ofuscada pelo prazer carnal, o que conduz o homem aos seus comportamentos mais animalescos. $\mathrm{Na}$ passagem de Cérbero, a besta mitológica é enganada pela sua maior fraqueza: a boca.

Fala-se na perda da agilidade da inteligência quando se come em quantidade demasiada. No entanto, a questão humana que está sendo tratada vai um pouco além. Devemos nos espelhar nas nossas sensações físicas para que a prática do exagero não ocorra, pois, assim como Santo Agostinho se lamentou por sua fraqueza diante da comida (Confissões X XXXI 47), o ponto da saciedade nem sempre é nítido para aquele que se alimenta, podendo-

\footnotetext{
53 "Que assim foi posto lá aonde tudo / o que se quer se pode, e tem valia." Ibid., p. 98.

54 "Uma dama desceu do céu fulgente / e fez-me dar-lhe ajuda e companhia." Ibid., p 348.
} 
se abandonar aquilo que se está ingerindo; com isso, o risco de incorrer no exagero é sempre presente. Já para Aristóteles, apenas a virtude da magnificência justificaria um exagero ( $E N$ 1121a 21-4), mas apenas se o acúmulo de riquezas conduzisse o seu proprietário a doar parte dela em benefício dos mais pobres.

É de se imaginar que, assim como para o filósofo, o guloso assuma para Dante uma espécie de caráter humorístico ${ }^{55}$. Isso justificaria até mesmo o tom mediano (ou "cômico") que a narrativa dantesca passa a ter a partir dessa personagem e que antes não se notava, como observa Chiavacci Leonardi (2005, Inf., p. 174). Situados ainda em um dos Cantos iniciais do poema, pode-se entender o fio narrativo de caráter médio que Dante almejou para a sua obra ao chamá-la de Comédia (DVE II v 3), no qual têm direito de cidadania não apenas os heróis, personagens da história ou grandes mitos; também o homem comum, até mesmo figuras pouco importantes dentre os seus contemporâneos, mas, nesse caso específico, não sem certa identificação por parte do poeta.

\subsection{A HUMANIDADE DA GULA}

Se pensada uma divisão no Canto VI do Inferno em duas partes, identifica-se ilustrado na primeira o pecado da gula e toda a sua bestialidade; na segunda parte, a gula é deixada de lado e são apresentadas profundas questões humanas, que se referem ao universo político da cidade de Dante e faz com que o poeta, mais uma vez, manifeste compaixão pelo condenado.

\section{(...) "Ciacco, il tuo affanno mi pesa sì, ch'a lagrimar mi 'nvita; \\ ma dimmi, se tu sai, a che verranno}

\footnotetext{
${ }^{55}$ Veja-se o comentário de Carlo Natali ao termo gastrimagoi, ou ventre voraz, usado por Aristóteles. EN 2005, p. 477 (EN 1118b 20).
} 
li cittadin de la città partita;

s'alcun v'è giusto; e dimmi la cagione

per che l' ha tanta discordia assalita", ${ }^{56}$

(Inf. VI 58-63, grifo meu)

Para Chiavacci Leonardi (2005, Inf., p. 186), a contínua e viva troca de frases entre o poeta e o pecador - característica de conexões familiares, segundo a comentadora - estabelece uma relação que ultrapassa a situação infernal e introduz uma relação no plano civil que se manifestará com as previsões de Ciacco sobre a cidade de Florença, pátria de ambos. Tal familiaridade do diálogo afasta qualquer tipo de repúdio do peregrino curioso em relação ao condenado, mas sim os aproxima humanamente em um tema comum, o futuro político de sua cidade. Vale lembrar que a contínua troca de frases não é uma exclusividade do episódio de Ciacco - a exemplo de Brunetto Latini (Inf. XV), a quem Dante conta toda a sua saga até chegar ao encontro de seu mestre. É, enfim, no Purgatório e no Paraíso que os grandes diálogos serão estabelecidos, como aquele com Estácio (Purg. XXI-XXXIII) e São Tomás de Aquino (Par. X-XIV), que se estenderão por vários Cantos.

De fato, como conclui Mattalia (1975, p. 140), Dante atesta uma substancial estima por Ciacco, já que certamente o poeta não teria pedido a uma pessoa de baixa dignidade moral e intelectual a difícil tarefa de esclarecer as causas da discórdia política pelas quais passava a sua cidade natal ${ }^{57}$. Ressalta-se que é exatamente no mesmo Canto VI, no qual se encontram os gulosos, que se apresenta outro tipo de relação com o desejo, do qual o poeta Dante demorará muito para se encontrar satisfeito:

E io a lui: “Ancor vo' che mi 'nsegni e che di più parlar mi facci dono.

\footnotetext{
56 ، 'Ciacco', tornei-lhe, 'minha compaixão / por ti é grande, e às lágrimas convida. / Dize, se o sabes, aonde chegarão / os filhos da cidade dividida; / se existe um justo ali; e, finalmente, / por que a cizânia a faz tão desunida?' Ibid., p. 123, grifo meu.

${ }^{57}$ Em toda a Comédia serão sempre os Cantos VI a recuperar a discussão política: no Inferno sobre Florença, com Ciacco; no Purgatório sobre a Itália, depois de encontrar Sordello de Mântua, e no Paraíso sobre o Império, com Justiniano.
} 
Farinata e 'l Tegghiaio, che fuor sì degni,

Iacopo Rusticucci, Arrigo e 'l Mosca

e li altri ch'a ben far puoser li 'ngegni,

dimmi ove sono e fa ch'io li conosca;

ché gran disio mi stringe di savere

se 'l ciel li addolcia o lo 'nferno li attosca". ${ }^{58}$

(Inf. VI 77-84, grifo meu)

Interessante notar que é exatamente em um dos círculos da incontinência que é explicitado por Dante um grande desejo de saber; nesse caso, se alguns antigos florentinos conhecidos foram condenados à vala infernal. Ciacco responde ao poeta que alguns lá se encontram e pede a Dante para ser lembrado na sua cidade; depois disso, os dois se despedem e o guloso segue envergonhado e triste. Será exatamente esse grande desejo de saber a ser posto em discussão nos próximos capítulos deste trabalho, principalmente de que forma o poeta relaciona essa vontade do conhecimento com muitas ideias que nos remetem principalmente ao universo da alimentação.

É no terceiro círculo do Inferno que Dante lembra o leitor da sua forma ainda encarnada e, por isso, ainda passível de ser acometida por grandes desejos, da mesma forma como sofreu o guloso Ciacco. Mas no caso do poeta, é outro tipo de desejo alimentar que o acomete: não o desejo pelo pão dos homens; sim o grande desejo que o fascina por saber (Inf. VI 83), o desejo pelo pan de li angeli (Conv. I I 7 / Par. II 11) que está tão presente também na próxima personagem a ser observada neste estudo: o grego Ulisses.

\footnotetext{
58 “'Peço-te', disse-lhe eu, 'se me consentes, / que vás mais longe me tua narração. / Farinata e Tegghiaio, proeminentes / e Jacó Rusticucci, e Mosca e Arrigo, / e outros, em suas obras diligentes, / dize onde estão, e se os verei, amigo; / quero saber se ao céu foram chamados, / ou arremessados neste atroz castigo.' " Ibid., p. 124, grifo meu. Note-se a perda da intensidade do original "grande desejo que me sufoca por saber"; contudo, o tradutor faz transparecer pelo adjetivo "amigo" o mesmo sentimento de compaixão aqui ressaltado.
} 


\section{ULISSES: BREVE PERCURSO DO HERÓI}

Após se aprofundarem pela vala da incontinência, Dante e seu guia Virgílio seguem em direção ao caminho que realizam pelos reinos de Lúcifer. Adentram os muros da cidade de Dite (Inf. VIII-XVI), onde presenciam a pena daqueles que pecaram pelo uso da violência contra o próximo, contra si mesmos e contra Deus. Em seguida, descem ao lugar chamado Malebolge (Inf. XVII-XXX), que se refere ao oitavo círculo infernal onde são punidos os que empregaram a fraude nas suas ações.

Muitos são os fraudulentos e muitas são as suas mentiras elencadas ali, mas é, em especial, a aparição do herói da antiguidade grega Ulisses a fazer da oitava fossa (Inf. XXVI) desse círculo um dos locais mais visitados pelos leitores da Comédia. O escritor Jorge Luis Borges (1999, p. 236), por exemplo, define esse episódio como "o mais alto da Comédia" devido ao seu enigma e à sua intensidade. Porém, tendo em vista o destaque que a personagem Ulisses ocupa na literatura ocidental, apresenta-se aqui um breve resumo sobre algumas obras em que o herói se faz presente pensando que Dante pode ter de alguma forma se baseado nelas para a sua narrativa.

Normalmente, a ideia que se tem do caráter de personagens homéricos é quase sempre baseado em fatos isolados da narrativa dos poemas Ilíada e Odisséia que alguns manuais oferecem. A intenção, aqui, não é fazer esse tipo de caracterização, mas sim uma espécie de retrato mais completo para o entendimento da questão tão discutida pela crítica dantesca. Propõe-se, nesse sentido, uma investigação sobre as origens de Ulisses, principalmente no que diz respeito ao seu comportamento com o uso da palavra, para que o retrato da personagem que é encontrado no círculo de Malebolge esteja um pouco mais nítido, no momento de passar à análise do texto dantesco. 
Por ser Ulisses uma figura amplamente discutida, tendo em vista o valor que essa personagem assume para a formação da cultura ocidental, são inúmeras as suas aparições no mundo literário até os dias de hoje. Contudo, o que se busca neste capítulo é traçar uma espécie de trajetória desde as suas intervenções na guerra de Tróia, narradas na Ilíada, e de suas errâncias pelo mundo antigo, descritas na Odisséia, ambos os poemas de Homero. Também será considerado o universo da tradição literária latina e os principais autores que podem ter servido de modelo para Dante, até chegar ao pecador que encontramos no oitavo círculo do Inferno dantesco. Porém, a maior ênfase será dada à caracterização de Virgílio na sua Eneida, principalmente pelo fato de ser o poeta latino a fazer de intermediário na conversa que Dante estabelecerá com Ulisses na vala dos fraudulentos.

\subsection{AS SUAS ORIGENS}

O primeiro texto de que se tem notícia a fazer menção a Ulisses é a Ilíada e, no primeiro Canto da obra, encontram-se referências positivas ao filho de Laertes. Ali, ele é descrito como o mais sagaz, a quem o rei dos aqueus, Agamenão, confia o comando do navio que vai devolver a sua escrava de guerra, Criseida, a Crises, pai da escrava e sacerdote do deus Apolo (Il. I 311). Desde a primeira aparição do herói, é possível distingui-lo como um exemplo de sensatez e equilíbrio, refletidos sempre por suas palavras (que na referida passagem são evidenciadas no discurso de redenção ao sacerdote e ao deus que aquele representava), denotando uma profunda maturidade do orador. Ainda nesse sentido, é Ulisses a aconselhar o rei Agamenão a se redimir com Aquiles à ofensa gerada ao guerreiro pelo episódio de outra escrava, Briseida, (Il. XIX 155), tirada de Aquiles pelo rei quando este ficara sem Criseida, seu troféu de guerra. Tanto no início quanto no fim do episódio das 
escravas, o papel de conselheiro que exerce Ulisses é indispensável, em um momento que pode ser caracterizado como de profunda "cegueira e engano" do comandante Agamenão ao se indispor com o herói Aquiles ${ }^{59}$.

Ao longo de todo o texto, em mais inúmeros exemplos, são sempre ressaltados os valores positivos de Ulisses, principalmente quando se trata de persuadir ou incentivar as tropas a lutarem. É a ele a quem a deusa Palas Atena se dirige, acatando uma ordem de deusa Hera, a fim de fazer com que o herói convença, com "palavras afáveis" (Il. II 174-81), os acaios a não abandonarem a guerra em busca da honra do rei Menelau, irmão do rei Agamenão. Isso faz dele um herói valoroso e um importante conselheiro, que por meio das palavras da deusa conduz os guerreiros à linha de frente nas batalhas (Il. II 284-332).

Explicitamente no referido trecho, Ulisses toma o cetro real das mãos do rei Agamenão e assume, mais uma vez, a postura de comandante das tropas, mostrando assim seu forte talento para conduzir os guerreiros com o poder da sua oratória, sendo logo definido como "astucioso, no saber comparável só a Zeus" (Il. II 636). Trata-se de um herói que até mesmo entre os inimigos é conhecido como o mais brilhante com as palavras, sendo assim retratado por Antenor em uma apresentação ao rei troiano Príamo (Il. III 191-216).

Também com as armas Ulisses se mostra um herói audaz, tido como um guerreiro solene (Il. X 381) e de grande importância para as tropas acaias. De baixa estatura, mas de peito largo (Il. III 200), esse "varão prudentíssimo" faz valer seu caráter combatente atravessando lanças e ferindo inimigos durante as batalhas, como no episódio que invade o acampamento inimigo durante a noite e elimina vários guerreiros (Il. X 482). Mostra-se também destemido ao reprovar duramente a atitude de Agamenão, que juntamente ao herói se encontrava ferido em seu navio e longe dos campos de batalha, quando o rei propõe que todos fugissem do combate (Il. XIV 29-83).

\footnotetext{
${ }^{59}$ Cf. MALTA, 2006.
} 
Todavia, é mesmo no âmbito das palavras e das ideias que se encontra a grande virtude do herói. No episódio em que Aquiles abandona as tropas, por não mais querer lutar por uma causa que não é sua, é justamente Ulisses a quem Agamenão nomeia embaixador, juntamente a Ajax e Fênix, para tentar dissuadir o pelida Aquiles e convencê-lo a voltar (Il. IX 168-81); a presença de Aquiles era tida como indispensável para o bom andamento dos resultados dos confrontos para o lado dos acaios, sendo ele reconhecido como o mais forte e valoroso entre todos os guerreiros vivos. Servindo de guia da embaixada, Ulisses profere um discurso para conquistar Aquiles e fazê-lo reintegrar a guerra. Tal discurso é perfeito do ponto de vista retórico se levados em conta os tópicos de uma boa oratória, seguidos por ele: (1) a envolvente dramatização dos fatos ocorridos na batalha, inclusive aqueles dos quais não se pode ter certeza, como a mentalidade do inimigo; (2) o apelo emocional aos sentimentos paternos de Aquiles, bem como ao dos inúmeros guerreiros que morreriam sem a sua presença; e, por fim, (3) uma valiosíssima oferta material em troca dos seus serviços como guerreiro, incluindo a restituição daquela que fora o estopim dessa discórdia entre Agamenão e Aquiles, a escrava Briseide (Il. IX 225-306) (CODINO, 1965, p.106).

Porém, apesar da perfeita retórica, nem tudo ocorre como o esperado. Mesmo reconhecendo o valor de Ulisses, Aquiles o acusa de pensar uma coisa e dizer outra - ou seja, mentir - deixando clara a sua aversão a tal ato: "repulsa me causa a pessoa que na alma esconde o que pensa e outra coisa na voz manifesta" (Il. IX 312-13). Nesse momento, Aquiles julga ser mais inteligente do que realmente está sendo, já que pressupõe ser vítima de um engano que nesse específico momento não existe. Como base de sua argumentação, Aquiles afirma ser consciente do próprio futuro, revelado por sua mãe, a deusa Tétis, e chega a usar por três vezes o verbo "enganar", referindo-se às intenções de Agamenão transmitidas pela embaixada. 
No entanto, Aquiles não poderia imaginar que o sofrimento das tropas ao qual se referia Ulisses é a morte de Pátroclo, suposta pelo herói quando menciona que vários serão os soldados a sofrerem sem a presença do pelida entre as tropas. Nessa citada passagem, Ulisses é considerado tanto um intruso - que toma a palavra inesperadamente quando não fora convidado a falar e inicia um acesso retórico - como um juiz, que conhece bem os dois lados em litígio e pode dar uma posição neutra e justa (CODINO, 1965, p. 106). Nota-se presente então uma constatação do caráter complexo do herói, que mesmo sendo um modelo em se tratando da sua capacidade com as palavras ou com as armas, pode ser também encarado como mentiroso.

Um pouco, mas não muito, diferente nesse aspecto é o Ulisses que se sobressai na Odisséia, também de Homero. Consideradas as teorias sobre a autoria e consecução dos poemas e da própria existência do poeta grego, a dita questão homérica ${ }^{60}$, é de se entender que o herói ali passe por algumas transformações. Nesse poema épico, está retratada a longa viagem que ele faz ao retornar à sua Ítaca natal e todos os obstáculos que encontra no caminho. Com isso, percebe-se que toda a segurança presente no Ulisses da Ilíada se dissipa no protagonista da Odisséia por estar o herói envolvido em situações das quais ele não tem mais o controle, onde ele é apenas um viajante obstinado a voltar para casa (GRIMAL, 1992, p. 235).

No preâmbulo da obra, menciona-se a sua incapacidade de salvar alguns companheiros na volta para casa, apesar de ter sofrido muito para fazê-lo (Od. I 6). Nesse momento, evidencia-se um herói que manifesta o desejo, por meio da voz de Palas Atena que se dirige a Zeus, no Olimpo, de voltar a Ítaca e morrer em paz. É também nesse citado trecho

\footnotetext{
${ }^{60}$ Divergência entre as correntes chamadas de Analista e Unitarista sobre a autoria dos poemas homéricos. A primeira defende que tanto a Ilíada quanto a Odisséia seriam vários pequenos poemas não criados por Homero, mas sim pelo povo grego de forma oral, tendo Karl Lachmann (Cf. Die Ilias und Homer, 1916) como um dos maiores defensores. Já a segunda defende a unidade do autor baseada na métrica, mas sobretudo nos epítetos fixos dos personagens, tendo em Milman Parry seu grande representante (Cf. L'épithète traditionelle dans Homère, 1928).
} 
que se encontra mencionada, pela primeira vez, o cavalo de madeira - motivo da vitória da guerra de Tróia - como obra do engenho de Ulisses, fato que consolidaria a audácia e esperteza do herói frente toda a antiguidade clássica.

Contudo, no que diz respeito à sua capacidade oratória, no início do poema, pode-se observar que para seus contemporâneos a imagem de Ulisses é sempre associada ao bom uso das palavras, seja para instruir como para conduzir seus companheiros. É o que nos faz crer Nestor, sábio ancião que acompanha as tropas acaias, quando ressalta a Telêmaco o valor de seu pai como orador. Tal valor se dá principalmente no que diz respeito à sua astúcia, depois de Telêmaco se dizer insatisfeito por ser filho do herói ardiloso (Od. III 120), que naquele momento se encontra perdido e desejoso de voltar para casa, segundo suas próprias palavras: "Que a este infeliz seja dado pisar o país de nascença pós tantas dores. Termine-se ali minha vida, após isso." (Od. VII 223-4).

Mesmo consideradas as correntes teóricas sobre a autoria dos poemas homéricos, não podemos negar também o caráter ambíguo do herói já nas narrativas gregas. Segundo Codino (1965, p. 132), Ulisses era capaz de tudo: é um modelo de lealdade, embora saiba inventar mentiras como nenhum outro; pensa sempre na sua casa, mas vai em busca de confusão pelo vasto mundo; é sábio e prudente, no entanto invade sem razão a gruta do Ciclope. Esses fatos refletem um caráter complexo e fazem com que Ulisses seja um dos personagens mais discutidos e citados ao longo de toda a literatura.

Para muitos autores latinos aos quais Dante possivelmente teve acesso - como Cícero (De Finibus V XVIII 48), para quem um grande homem como Ulissses não seria enfeitiçável pelo canto das sereias dada a sua tamanha inteligência; ou mesmo Sêneca ( $D e$ Constantia Sapientis II 2), que o cita como modelo de sabedoria e força -, o herói era um modelo de virtude e discernimento assim como para os gregos. Porém para outros, como o poeta Ovídio (Metamorfoses XIII-IV), o herói sabia de seus limites, porém a eles era 
indiferente, transparecendo um equilíbrio duvidoso no que se refere ao seu caráter. Ovídio (Metamorfoses XIII 5-18), em um momento, relata o heroísmo de Ulisses sendo contestado por Ajax, seu ex-companheiro, quando eles conversam no hades. Sem dúvida, Dante teve acesso a esse autor, principalmente pelo fato de o poeta ter iniciado a aventura do Ulisses da Comédia no exato ponto onde o latino, em outro momento, o havia deixado: nas terras de Circe (Metamorfoses IV 241 et seq.).

Ovídio não está sozinho nessa caracterização; é bem conhecido o retrato que o poeta Virgílio cria do herói (En. II-III), fazendo com que na tradição literária latina, principalmente, origine-se um movimento que procura não ressaltar os atos valorosos de Ulisses, mas sim enxergá-lo sob uma perspectiva que questiona a virtuosidade do seu heroísmo. Quando Virgílio narra, no seu poema, as aventuras de Enéias antes de sua chegada à terra prometida pela deusa Vênus - terras italianas a partir de onde começaria a nova estirpe dos romanos parece que tem por referência o lado troiano da guerra, que sofreu abusos por parte de Ulisses quando o itacense inventou um modo de introduzir o cavalo de madeira na cidade que depois viria a ser derrotada.

É presente, logo no início do segundo livro do poema virgiliano, o apelo emocional que o narrador Enéias faz aos seus interlocutores, explicando que nem mesmo os soldados do "duro" Ulisses ficariam indiferentes às palavras que estava para expor e se derramariam em lágrimas (En. II 7): Enéias introduz a narrativa da queda de Tróia, sua cidade. Logo no início do relato, no momento de receber dentro da cidade o cavalo de madeira, é mediante as palavras do sacerdote troiano do deus Netuno, Laocoonte, que a honestidade de Ulisses é posta em questão:

- Cidadãos infelizes, que insânia vos cega? Imaginais por ventura que os gregos já foram de volta, ou que seus dons sejam limpos? A Ulisses, então, a tal ponto desconheceis? Ou esconde essa máquina muitos guerreiros, ou fabricada ela foi para dano de nossas muralhas, 
e devassar nossas casas ou do alto cair na cidade.

Qualquer insídia contém. Não confieis no cavalo, troianos!

Seja o que for, temo os dânaos, até quando trazem presentes. ${ }^{61}$

(En. II 42-9)

Em seguida, destaca-se o herói grego definido como um homem "ganancioso e pérfido" (En. II 89), como aquele que tece "acusações inaudíveis" (En. II 96-7) e como vingador implacável (En. II 103); todas acusações feitas por palavras atribuídas a Sínon ${ }^{62}$ como sendo parte do plano para introduzir o cavalo na cidade do rei Príamo. Durante o falso depoimento de Sínon, inserida na narrativa de Enéias, é presente uma forte e negativa caracterização de Ulisses. Essa ideia permanece ao longo do segundo e do terceiro livros da obra, sendo ele definido como "de todo o mal o inventor" (En. II 163), o agressor de Pélias (En. II 435) e merecendo até mesmo epítetos por parte de Virgílio, "Ulisses, o cruel” (En. II 260/761; III 271) e "Ulisses, o infortunado" (En. III 611/689). Essa seria uma possível caracterização que influenciaria outros poetas como Estácio ${ }^{63}$, que se refere a Ulisses como um fraudulento quando ele descobre Aquiles escondido entre mulheres na ilha de Lemno (Achilleida I 846).

Chiavacci Leonardi (2005, Inf., 779,) observa que, no caso específico das fontes de Dante, não se pode deixar de lado o fato que o poeta não era versado em língua grega, sendo os autores latinos um elo de fundamental importância para que ele conhecesse todo o referencial helênico presente na sua obra. No que se diz respeito às fontes clássicas, sabe-se do grande valor que Ulisses tinha frente aos seus companheiros nas narrativas de Homero; ele aconselhava, convencia, planejava estratégias de sucesso, enfim, era conhecido pelo valor de seu grande intelecto. Mas como afirma Jaeger (2001, p. 62), “o Cristianismo converteu a

\footnotetext{
${ }^{61}$ Trad. NUNES, 1981, p. 30.

${ }_{62}^{62}$ Punido também na Comédia (Inf. XXX 98 et seq.) como um falsificador da própria pessoa.

${ }^{63}$ Publius Papinius Statius. (Nápoles, 45(aprox.) - 96 d.C.), outro poeta importante para Dante e que tem seu valor reconhecido na subida da montanha do paraíso terrestre (Purg. XXI-XXXIII).
} 
avaliação puramente estética da poesia em atitude espiritual predominante", sendo difícil apontar onde se iniciam exatamente os questionamentos sobre a índole de Ulisses.

É de se crer que as referências à passagem por um mundo de realidade tão extrema como o hades, mencionada tanto na Odisséia como nas Metamorfoses, se façam pela profundidade que as experiências deixam em quem passa por lá, o que daria mais complexidade à sua personalidade. De fato, desde os poemas homéricos até chegar a Ovídio, Ulisses tem passado por esse mundo espiritual. Em Homero, é lá que ele encontra Tirésias, um sábio adivinho tebano, que faz previsões sobre a sua morte (Od. XI 134-7) que deixam transparecer uma ambiguidade da qual se aproveitaram os autores que continuaram o percurso do herói. O verso thánatos eks halós (Od. XI, 134) do texto homérico pode ser lido como "longe do mar salino" ou "que procede do mar salino", deixando a previsão aberta a futuras exposições ${ }^{64}$. E é justamente lá no hades, ou melhor, no Inferno, que encontra-se o nosso Ulisses dantesco, não mais desejoso de voltar para casa, mas sim de ir além.

\subsection{O ULISSES DA COMÉDIA}

O pequeno percurso sobre as aparições de Ulisses apresentado corresponde à sua trajetória no universo das literaturas clássicas grega e latina, embora o herói que se vê na narrativa dantesca não seja menos valoroso e nem subjugado. Prova disso são as palavras de Virgílio que relatam uma pequena parte de sua história para que não haja dúvidas de quem se está falando. Pela vontade que Dante manifesta em saber sobre o que se tratavam as chamas do fundo da fossa infernal, Ulisses é apresentado pelo guia Virgílio como o criador do cavalo de madeira que provocou a queda de Tróia e o início da civilização romana. Essa seria a razão

\footnotetext{
${ }^{64}$ Disso se aproveitou também Haroldo de Campos em seu poema Sobre Finismundo: A última viagem (CAMPOS, 1996, p.40).
} 
pela qual ele é punido no oitavo círculo, reservado aos que teceram fraude contra quem não confiava, nesse caso, os troianos. O laértida não está sozinho, pelo contrário, ele é punido dentro de uma chama dividida em duas, onde a mais alta o representa e a outra, o seu companheiro Diomedes.

"Maestro mio", rispuos'io, "per udirti
son io più certo; ma già m'era avviso
che così fosse, e già voleva dirti:
chi è 'n quel foco che vien sì diviso
di sopra, che par surger de la pira
dov'Eteòcle col fratel fu miso?".
Rispuose a me: "Là dentro si martira
Ulisse e Dïomede, e così insieme
a la vendetta vanno come a l'ira;
e dentro da la lor fiamma si geme
l'agguato del caval che fé la porta
onde uscì de' Romani il gentil seme.
Piangevisi entro l'arte per che, morta,
Deïdamia ancor si duol d'Achille,
e del Palladio pena vi si porta".
(Inf. XXVI, 49-63)

Segundo Auerbach (2008, p. 78), os homens que aparecem na Comédia já se encontram destacados de seu tempo e de seu destino histórico, o que permite a Dante escolher para sua representação poética uma cena particular que lhe ofereça novas possibilidades de expressão. Com isso, nessa apresentação são ressaltadas três fraudes: a do cavalo de madeira (1), da qual Ulisses foi mentor para provocar a queda da cidade de Tróia, narrada por Homero (Od. VIII 499-520) e recuperada por Virgílio (En II-III); a descoberta de Aquiles na ilha de Deidamia (2), onde Dante faz referência a outro modelo literário, o poeta Estácio (Purg. XXI 91), que menciona Ulisses como um fraudulento quando ele descobre Aquiles escondido entre mulheres na ilha de Lemno (Achilleida I 846 / Purg. XXI 92); e a da estátua do Paládio (3),

\footnotetext{
65 "Ouço-te, mestre", eu disse, "e é suficiente; / mas na verdade o tinha percebido, / e nisto ia falar-te, exatamente: / Quem é que vai no lume dividido / ao topo, que a indicar parece a pira / onde, co' o irmão, Eteocles foi metido?"/ "Ulisses e Diomedes, por mentira", / tornou-me, "nela vão, juntos marchando / à vingança de Deus, tal como à ira. / No invólucro de fogo ei-los chorando / a fraude equina, pela qual um dia / foi de Roma a semente germinando; / e mais o ardil que, morta, Deidamia / fez por Aquiles inda prantear; / e do Paládio a máxima ousadia.” Ibid., p. 268.
} 
destruída pelos dois heróis punidos ali e mencionada também por Virgílio (Eneida II 163), rendendo aos dois heróis adjetivos diferentes: "ímpio" a Diomedes e "de todo o mal inventor" a Ulisses.

Nenhuma surpresa do leitor ao ver que era Ulisses o mentor das três fraudes, fato que lhe rendeu um epíteto negativo por parte de Virgílio, mas é interessante pensar o porquê de Ulisses ser punido na mesma chama que o ímpio Diomedes, deixando que Sínon, responsável pela entrada do cavalo na cidade de Tróia, ele sim, seja punido sozinho e como um falsário no fundo de Malebolge (Inf. XXX 98).

Quando o laértida toma a palavra, após ser convidado por Virgílio, é explicitada a menção que se faz não a uma fraude contra Tróia; Ulisses narra como decidiu e convenceu seus poucos parceiros a seguir em uma viagem rumo a conhecer o mundo, o valor e os vícios humanos, vencido pelo ardor de conhecimento. Um ardor que foi capaz de superar até mesmo os valores afetivos que o herói sabia poder encontrar na sua família (Inf. XXVI 94-6). Em seguida, percebe-se pelo relato de Ulisses que essa viagem geraria a sua morte bem como a de seus companheiros logo que eles avistam a montanha do paraíso terrestre, no hemisfério da águas, depois de cinco meses de viagem. Volta-se a falar da fraude propriamente dita apenas no Canto seguinte (Inf. XXVII), quando é apresentada a personagem Guido da Montefeltro, não mais uma figura lendária como Ulisses e sim um nobre contemporâneo a Dante que realmente existiu; a quem Dante fala diretamente após Virgílio assegurar-lhe que era latino, e não grego como Ulisses.

Chiavacci Leonardi (2005, Inf., p. 776) observa nesse episódio dois Ulisses diferentes: o da Ilíada/Eneida, ao qual se refere Virgílio nessa apresentação quando lista as suas culpas; e o da Odisséia, aquele que Dante usa como modelo para o seu episódio sobre a busca de experiências pelo exemplo que se tinha, na Idade Média, no herói clássico como um homem que buscava aventuras que o enriquecessem. Nesse sentido, também vai a leitura de 
Grimal (1992, p. 235), quando diz que o Ulisses da Odisséia é muito mais inseguro e sofrido do que aquele forte e terrível guerreiro da Ilíada.

Muitos são os comentadores que, não obstante a condenação explícita do herói grego, observam o distanciamento de Ulisses da vala dos fraudulentos. Chiavacci Leonardi (2005, Inf., p. 797), ressalta que ao mesmo tempo em que se vê o conde de Montefeltro imerso entre os fraudulentos, Ulisses é absolutamente destacado dessa fossa. Fubini (1963, p. 1/42) considera o herói "idealmente liberto da atmosfera infernal" pela sua vontade de conhecimento, afirmando que nitidamente o poeta estudou a fundo para que esse episódio ficasse separado da comédia infernal não apenas pela personagem, mas também pela linguagem de todo o Canto, o que se mostra claramente na representação pictórica que o poeta inglês William Blake fez para a cena do encontro dos dois poetas com o herói ${ }^{66}$. Também para Auerbach (2008, p. 137), que afirma ser Ulisses um dos poucos condenados que no momento da lembrança não cita o seu crime de fraude, mas sim a falta de paz na própria pátria e a "vontade desmedida de saber". É na tentativa de entender o destaque que Ulisses ocupa entre os pecadores da oitava vala que se apresenta o estudo do próximo capítulo.

\footnotetext{
${ }^{66}$ Cf. BLAKE, 2008.
} 


\section{ULISSES E O DESEJO EXCESSIVO DE SABER}

Na Comédia (Inf. XXVI), o que se apresenta é um novo retrato de uma personagem clássica. Ali, Ulisses não faz desaparecer o seu passado, mas narra uma trajetória para si e para seus companheiros bem diferente daquela que o mundo antigo conhecera. Para Dante, o herói grego foi em busca de virtude e conhecimento, uma espécie de alimento para a alma, assim como Ciacco se fartou de comida para saciar seus prazeres. Para melhor entender a relação entre as duas personagens - uma punida pela incontinência, outra pela fraude considera-se, a partir deste capítulo, o modo como o próprio poeta explicita a conexão entre o ato de se alimentar (para nutrir o corpo de suas necessidades vitais) e aquele de se instruir, para alcançar "a última perfeição da nossa alma" (Conv. I I 1).

Giovanni Boccaccio, indiscutivelmente um dos primeiros comentadores de Dante pela proximidade temporal à sua obra, descreve o poeta como um "pastor" por fornecer alimento ao intelecto daqueles que disso precisavam (Trattatello in laude di Dante XXIX). Mas é ao ver como o próprio Dante estreita essa relação entre o saber e o sabor, que o objeto desta pesquisa se torna mais intrigante. Surge, no primeiro capítulo do Convivio, valorizado o conceito aristotélico de como os homens naturalmente desejam o saber, a ideia que guiará o poeta na escrita do seu tratado filosófico. De acordo com Pietrobono (1953, p. 16), Dante acreditava ser a razão capaz de saciá-lo em qualquer tipo de sede, fato que pode ter levado o autor a escolher como título para a sua obra um termo diretamente ligado à alimentação: Convivio, em língua italiana, é denotado como uma refeição solene e farta, merecendo o título de $O$ Banquete ${ }^{67}$, em língua portuguesa, e The Banquet ${ }^{68}$, em língua inglesa. Essa aproximação do conhecimento humano relacionado ao alimento pode ter início no livro

\footnotetext{
${ }^{67}$ ALIGHIERI, Dante. O Banquete. In: Obras completas. Trad. Padre Vicente Pedroso. São Paulo: Editora das Américas, [1957]. Vol. VIII. Preferiu-se manter o título original Convivio nas citações desta pesquisa pela familiaridade com que os estudiosos de Dante mantêm com ele.

${ }^{68}$ Dante's Il Convivio (The Banquet). Trad. Richard H. Lansing. Nova York: Garland, 1990.
} 
bíblico dos Salmos, onde é feito um louvor à justiça divina e uma invocação a que o homem conheça Deus pelo seu sabor: "Provai e vede como Iahweh é bom, / feliz o homem que nele se abriga" (BÍBLIA, 2003. Sl 34 [33] 9, grifo meu).

Nesse sentido, ainda no Convivio, várias são as menções que o próprio poeta faz ao universo alimentar ligado ao da instrução intelectual, principalmente no capítulo de abertura da obra; a exemplo, ao se referir aos que não tiveram acesso ao saber como aqueles que "desse alimento continuam com fome" (li 'mpediti che di questo cibo sempre vivono affamati. Conv. I I 6); ao louvar aqueles poucos que se sentam à mesa onde o "pão dos anjos" é consumido (Oh beati quelli pochi che seggiono a quella mensa dove lo pane delli angeli si manuca! Conv. I I 7); ao constatar que por um ato de misericórdia os sábios devem ser como "fontes daquela água que refresca a sede natural" para os mais pobres (coloro che sanno porgono della loro buona ricchezza alli veri poveri, e sono quasi fonte vivo, della cui acqua si refrigera la naturale sete [...]. Conv. I I 9); ao reconhecer-se humildemente entre os excluídos de tal mesa dos sábios, mas ao colocar-se ao pés daqueles por já ter "recusado o alimento das multidões" (fuggito della pastura del vulgo. Conv. I I 10); ao apresentar como base do "alimento" oferecido aos seus leitores o referido "pão", que esclarece as obscuridades do seu texto (La vivanda di questo convivio [...] sanza lo presente pane aveano d'alcuna oscuritade ombra [...]. Conv. I I 14).

Esse tipo de representação não se faz presente apenas no tratado filosófico do poeta, também na Comédia é evidente a maneira como Dante estabelece um paralelo entre as duas vontades de alimento, seja para o corpo, seja para o espírito. Inicialmente pode-se enxergar uma vontade além da conta por parte do poeta exatamente na vala infernal dos gulosos, com os já citados versos nos quais Dante se mostra desejoso de saber sobre as figuras políticas de sua cidade natal (gran disio mi stringe di savere. Inf. VI 83). A conexão entre as vontades de saber e de sabor se manifesta na vala dos iracundos, onde o conhecimento se realiza por meio 
do ver e o guia Virgilio recomenda que Dante goze dos prazeres da visão porque deles será saciado, adjetivo normalmente associado à alimentação ("Avante che la proda / ti si lasci veder, tu sarai sazio: / di tal disïo convien che tu goda”. Inf. VIII 55-7); e na vala dos enganadores, onde o poeta reconhece um dos condenados e o revela a Virgílio com uma metáfora alimentar, não estando "em jejum de ver" ( "Già di veder costui non son digiuno". Inf. XVIII 41-2 / XXVIII 87); e no momento em que é questionado por um dos enganadores punido naquela vala sobre a intensidade gulosa do seu olhar ("Perché se' tu sì gordo di riguardar più me che li altri brutti?" Inf. XVIII 118-9); e no fim da mesma vala, onde o narrador revela já saciado o desejo de ver dos viajantes (E quinci sian le nostre viste sazie. Inf. XVIII 136).

O empréstimo lexical do universo alimentar não está presente apenas no Inferno, mas também nas segunda e terceira cantiche do poema. Nota-se essa relação no Purgatório, onde as almas recém chegadas a um lugar desconhecido são retratadas como aquelas que experimentam novas coisas (come colui che nove cose assaggia ${ }^{69}$. Purg. II 52-4); e no círculo no qual os acidiosos purgam pela sua vontade fraca diante do bem, onde o poeta assume que a sua sede de saber pode incomodar seu guia (e io, cui nova sete ancor frugava, / di fuor tacea, e dentro dicea: "Forse / lo troppo dimandar ch'io fo li grava”. Purg. XVIII 4-6); e no círculo no qual são purgados os pecados da avareza e da prodigalidade, onde o poeta explicita ser a "sede natural dos homens" saciável apenas com a revelação divina (La sete natural che mai non sazia / se non con l'acqua onde la femminetta / samaritana domandò la grazia. Purg. XXI 1-3). Nesse último ponto, Chiavacci Leonardi (2005, Purg., p. 611) atenta para a relação que se cria com o herói Ulisses, "a grande contra-figura infernal de Dante que quer saciar a sua ardente sede percorrendo com meios humanos o infinito mar". Além desse ponto, a "natural sede" será mencionada ainda duas vezes no mesmo Canto (Purg. XXI 39 / XXI 73-

${ }^{69}$ É de se observar que na língua italiana o verbo assaggiare mantém uma estreita ligação com o contexto alimentar, sendo definido como "provar o sabor de uma comida ou bebida em quantidade pequena". Cf. ZINGARELLI, 2001, p. 106. 
5); e também no momento em que os poetas passam do círculo dos gulosos ao dos luxuriosos, onde é mencionada uma possível ${ }^{70}$ sede de saber de um dos presentes (rispondi a me che 'n sete e 'n foco ardo. Purg. XXVI 18); e mais uma vez quando, já no paraíso terrestre, a misteriosa Matelda responde a duas perguntas de Dante, considerando que naquele momento a sede dele já possa estar saciada (E avvegna ch'assai possa esser sazia / la sete tua perch'io più non ti scuopra. Purg. XXVIII 134-5); e ainda quando Dante se revela muito feliz ao experimentar aquele alimento que "quanto mais se consome, mais quer ser consumido" (l'anima mia gustava di quel cibo / che, saziando di sé, di sé asseta. Purg. XXXI 128-9) e que se trata da sabedoria divina, segundo Chiavacci Leonardi (2005, Purg., p. 925).

Dessa mesma maneira, a relação entre o sabor e o saber se manifesta também na cantica do Paraíso, a exemplo do momento em que o poeta Dante clama ao leitor a importância de se alimentar do "pão dos anjos" (pan de li angeli. Par. II 10) aquele que no Convivio se tratava da filosofia, mas que aqui representa mais uma vez a sabedoria divina, segundo Chiavacci Leonardi (2005, Par., p. 53); a exemplo também de quando duas verdades são reveladas, por Piccarda e por Beatriz, e o poeta se põe como alguém que antes "morria de fome" e que agora está "diante de dois alimentos" (Intra due cibi, distanti e moventi / d'un modo, prima si morria di fame. Par. IV 1-3); e, pouco depois, quando o poeta assume a insaciabilidade do seu intelecto (Io veggio ben che già mai non si sazia / nostro intelletto. Par. IV 124-5), quase como a falar de um estômago faminto, mas "tratando do processo sempre renovador da consciência humana, que se acalma apenas quando atinge a verdade última e suprema, e descrevendo a história da sua vida e do seu poema" (CHIAVACCI LEONARDI, 2005, Par., p. 122); e quando, observando o movimento dos astros no céu dos sábios e admirando a complexidade da trindade divina, o poeta convida o leitor a se nutrir

\footnotetext{
${ }^{70}$ Chiavacci Leonardi (2005. Purg., p.769) afirma ser essa sede indissociável da chama que purifica, citando comentadores prestigiados como L'Ottimo, Buti e Sapegno. Contudo, não vê dessa forma a maioria dos comentadores, como menciona o próprio Sapegno (1955-57, Purg. 26.18), que associam essa sede com o desejo de saber.
} 
daquilo que ele está lhe servindo, referindo-se à sua poesia e ao significado que ela traz consigo como um alimento a ser saboreado e que traz a felicidade:

\author{
Or ti riman, lettor, sovra 'l tuo banco, \\ dietro pensando a ciò che si preliba, \\ s'esser vuoi lieto assai prima che stanco. \\ Messo t' ho innanzi: omai per te ti ciba. ${ }^{71}$ \\ (Par. X 22-5)
}

Ainda, no mesmo céu dos sábios, quando através das palavras de São Tomás de Aquino tem-se o vinho que pode aplacar a sede do poeta (il vin de la sua fiala / per la tua sete. Par. X 88-9) como, segundo Chiavacci Leonardi (2005, Par., p. 286), "a sabedoria que pode apaziguar o desejo de conhecer" de Dante; e, ainda no céu do Sol, o dos sábios, quando é apontada a alma do rei Salomão, de quem o mundo terreno ainda está "guloso" por saber novidades, se ele foi salvo pela sua sabedoria ou condenado pela sua luxúria (che tutto ' $l$ mondo / là giù ne gola di saper novella. Par. X 110-1); e quando Dante encontra no céu de Mercúrio seu ancestral Cacciaguida, a quem pede para ser saciado do desejo de saber o nome (Ben supplico io a te, vivo topázio [...] perché mi facci del tuo nome sazio. Par. XV 85-7); e quando o poeta se depara no céu de Júpiter com a águia formada pelas almas dos justos, a quem pede para ser "libertado do grande jejum" ao perguntar sobre a culpa daqueles que não conheceram a fé cristã, referindo-se à questão como uma "fome que em terra nunca encontrara alimento adequado" (solvetemi, spirando, il gran digiuno / che lungamente $m^{\prime}$ ha tenuto in fame, / non trovandoli in terra cibo alcuno. Par. XIX 25-7); e, mais uma vez, quando a metáfora do alimento que satisfaz encontra uma alta celebração, no momento em que a guia Beatriz apresenta o peregrino Dante aos apóstolos (convidados ao grande jantar do Cordeiro) como aquele que se alimenta do que cai da mesa dos santos:

\footnotetext{
71 “Ora, leitor, meditação pausada / faz de quanto comigo prelibaste: / Leda a mente hás de ter, não saciada. / Dou-te iguaria: come, pois, se praz-te.” Trad. XAVIER PINHEIRO, 1958, p. 287.
} 


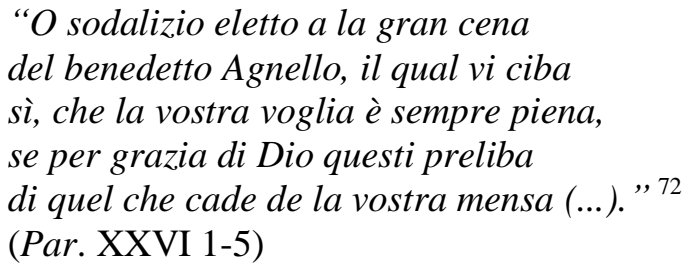

E, ainda no Paraíso, quando o poeta faz referência aos que vieram de uma zona remota da Croácia para ver o véu com a imagem do rosto de Cristo ${ }^{73}$, e daquela "antiga fome [de ver] nunca se saciavam" (Qual è colui che forse di Croazia / viene a veder la Veronica nostra, che per l'antica fame non sen sazia. Par. XXXI 103-5); e finalmente quando Dante está para ser exposto à visão divina, aquela que segundo o poeta é o objetivo de todos as vontades, ele leva ao ápice todo o seu ardor de desejo ( $E$ io ch'al fine di tutt'i disii / appropinquava, sì com'io dovea, / l'ardor del desiderio in me finii. Par. XXXIII 46-8), como ele próprio já tinha explicado ser o natural das vontades humanas (Conv. III X 2).

Interessante notar que o ardor que o poeta sente aumentar no momento da visão beatífica é o mesmo ardor que moveu Ulisses a buscar o desconhecido (l'ardore... a divenir del mondo esperto. Inf. XXVI 97-8). Segundo Chiavacci Leonardi (2005, Inf., p.778), o ardor com o qual Dante se curva no momento de pedir a Virgilio que o faça ver a chama de Ulisses (vedi che del disio ver' lei mi piego! Inf. XXVI 69), quase atraído irresistivelmente em direção à labareda do herói antigo, é sinal de uma profunda paixão do ânimo do poeta; para a comentadora, toda a história de Ulisses representa um fato do espírito que o próprio poeta viveu.

\footnotetext{
72 "O sodalício, à ceia convidado / do cordeiro de Deus, que dá sustento / tal, que o apetite heis sempre saciado, / se inda antes de chegar ao passamento / preliba este homem - assim Deus dispensa - / da mesa, em que comeis, tênue fragmento (...).” Trad. XAVIER PINHEIRO, 1958, p. 327.

${ }^{73}$ Sudário conhecido na Idade Média como "Veronica", nome fundado em duas palavras, vera icona: verdadeira imagem. Dante se refere a essa imagem também na Vita Nuova (XL 1) como um objeto de grande veneração e peregrinação.
} 


\title{
5.1 A BUSCA PELA SABEDORIA
}

É necessário que se tenha sob perspectiva todo o Canto XXVI do Inferno para que se possa ver uma vontade exagerada de saber por parte de Ulisses. Nesse Canto, se apresenta um narrador tomado pela sua veia política ao abri-lo, tendo como referência aqueles punidos dentro do círculo anterior, os ladrões, entre os quais Dante encontra cinco dos seus conterrâneos. Com isso, o poeta lança uma ofensiva contra a sua cidade natal que se estende pelas três primeiras estrofes.

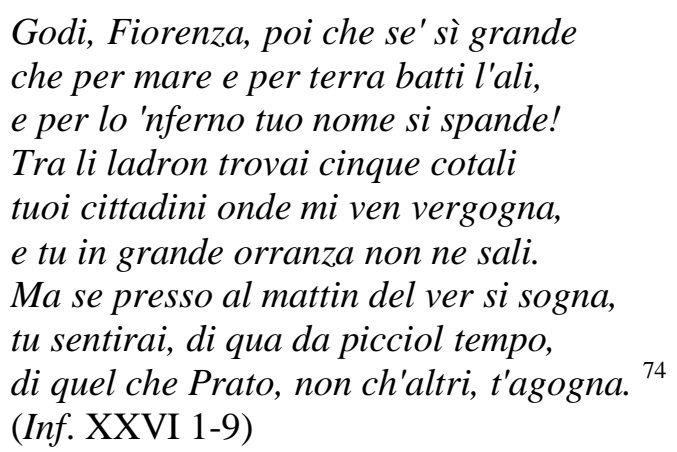

Logo em seguida, o poeta se compadece daquilo que deve começar a narrar, e essa compaixão é mostrada pela dor que ele sente ao lembrar o que presenciou naquele círculo. Mas é pela menção que Dante faz ao fato de depender da virtude no impulso do seu pensamento que o aproxima daquilo que irá contar, ou seja, a última viagem de Ulisses.

\author{
Allor mi dolsi, e ora mi ridoglio \\ Quando drizzo la mente a ciò ch'io vidi, \\ e più lo 'ngegno affreno ch'i' non soglio, \\ perché non corra che virtù nol guidi; \\ sì che, se stella bona o miglior cosa \\ $m$ ' ha dato 'l ben, ch'io stessi nol m' invidi. ${ }^{75}$ \\ (Inf. XXVI 19-24, grifo meu)
}

\footnotetext{
74 “Florença, exulta, que és formosa e grande! / Vibras as asas sobre a terra e o mar, / e até no inferno o nome teu se expande! / Com os ladrões, magoados, fui achar / cinco dentre os teus filhos, de imediato; / ali por certo não te estão a honrar. / Se o sonho matinal inculca o fato, / hás de sentir na carne, e sem demora, / o mal que contra ti se engendra em Prato.” Ibid., p. 266.

75 "Subito, olhei, e vi - quanta amargura! - / algo que ainda me dói ao relembrá-lo: / que ao meu engenho a rédea vá segura, / para sempre à virtude conformá-lo; / já que uma boa estrela o dom me estende / de ver o bem, que eu possa conservá-lo!". Ibid., p. 267, grifo meu.
} 
Como afirma Fubini (1963, p. 31), tais versos servem como anúncio da nova pena e do pecado que essa castiga: o pecado do mau uso da inteligência, do engenho humano não guiado pela virtude.

Para Aristóteles (EN 1145a 2-4), a grande virtude necessária à consagração das outras é a prudência ${ }^{76}$, de forma que exista uma conexão entre todas as qualidades de um homem bom e justo e ele possa ser chamado de virtuoso até mesmo se possuir unicamente essa importante qualidade moral. Borges (1999, p. 396) na leitura desse Canto, fazendo menção a outros críticos ${ }^{77}$, julga esse trecho como uma digressão de Dante, onde o poeta usa a figura de Ulisses para ocultar uma reflexão maior e não apenas para lembrar episódios fraudulentos como o da guerra de Tróia. Seria, portanto, essa possível digressão um desvio momentâneo que o poeta faz da discussão central do Canto - a fraude - e busca uma reflexão sobre os limites do conhecimento humano.

Essa digressão presente no Canto XXVI do Inferno está longe de ser a única ocorrência dentro da obra, basta lembrar o Canto VI, discutido anteriormente, e a sua inicial proposta de ilustrar o pecado da gula. Parece que após apresentar Ciacco como um homem que sucumbiu aos prazeres da mesa, Dante serve-se dele para exultar fatos históricos sobre a sua cidade natal, propostos como previsões do guloso, dando início a um caráter político que os Cantos VI das três cantiche manterão. O próprio Dante, em outro momento (Conv. IV VIII 10), assume o quão longas podem ser as suas digressões.

Nesse sentido, tendo apoio sobre uma possível digressão do Canto de Ulisses, bem como nas várias referências apresentadas em que o poeta relaciona o universo da nutrição àquele da instrução, a proposta deste trabalho é ampliar a noção de incontinência para além do exagero dos evidentes desejos corporais do homem. Para isso, é de fundamental importância

\footnotetext{
${ }^{76}$ Lida também como "sabedoria" (saggezza) em EN 2005, p. 253. Trad. Carlo Natali.

${ }^{77}$ Como o Anônimo Florentino (1400[?]) e Raffaello Andreoli (1856).
} 
que se estabeleça também como fome/sede natural a noção que se refere à busca pelo conhecimento que conduz à sabedoria.

Impõe-se, portanto, uma questão delicada: qual seria o limite do conhecimento para que não seja condenável frente à ética cristã que rege o poema dantesco; como a ideia de incontinência com o sentido de extrapolação desses limites pode ser aplicada no caso de Ulisses? Para uma tentativa de resposta, pode-se reconhecer a incontinência a partir de sua raiz grega, o termo acrasia. Nesse, é denotada a falta de poder sobre qualquer coisa, especialmente de uma pessoa sobre si mesma, o que configura uma imprudência frente a um bem maior, a virtude. Para Mora (2000, p. 46), a acrasia mostra-se a partir de ações que conduzem o sujeito a agir intencionalmente, mesmo que passe por cima de seus próprios valores; e como ressalta Codino (1965, p. 98), não se pode negar completamente a liberdade dos heróis homéricos e, portanto, uma responsabilidade individual separada da vontade coletiva e independente dos decretos das divindades.

No comentário de Carlo Natali à sua tradução italiana da Ética a Nicômaco (EN, 2005, p. 514), é chamada a atenção para o valor que o termo grego acrasia assume em determinados pontos ${ }^{78}$, onde perde a denotação tradicional de "egoísmo material", merecendo uma tradução diferente da costumeira incontinenza. Nesses pontos, o que antes era visto de maneira restrita aos egoísmos ligados aos prazeres do corpo acaba sendo traduzido como "falta de autocontrole". Para tanto, tem-se como base a consideração de Aristóteles (EN 1119a 1-5) de que o intemperante e, portanto, também incontinente de maneira mais ampla ${ }^{79}$, deseja aquilo que lhe dá prazer de um modo particular e é impulsionado a fazer escolhas, mesmo que nelas esteja incluído o sofrimento.

Fubini (1963, p. 19), ao lembrar os versos onde São Tomás de Aquino fala diretamente a Dante (Par. XI 27), salienta que o desejo de saber não é por si só pecaminoso,

\footnotetext{
${ }^{78}$ Como em EN 1145a 17.

${ }^{79}$ Em EN 1145b 15-6 é afirmado o caráter incontinente do intemperante e vice-versa.
} 
"mas é importante que se distinga entre o êxito da empreitada, que Deus não poderia permitir que se realizasse, e a intenção de Ulisses". Segundo o comentador, "o que faltou ao herói foi a graça, a fé, sem a qual o desejo de conhecer não pode alcançar a sua completude”. Nesse sentido, propõe-se a fala de Virgílio no Purgatório:

\footnotetext{
"State contenti, umana gente, al quia; ché, se potuto aveste veder tutto, mestier non era parturir Maria; e disiar vedeste sanza frutto tai che sarebbe lor disio quetato, ch'etternalmente è dato lor per lutto: io dico d'Aristotile e di Plato e di molt'altri", e qui chinò la fronte, e più non disse, e rimase turbato. ${ }^{80}$ (Purg. III 37-45)
}

Com a referência direta aos grandes sábios da antiguidade, o poeta latino nos lembra que apenas o desejo de saber não é suficiente para que a alma seja salva. Aristóteles e Platão, bem como os outros filósofos mencionados no Nobre Castelo, atingiram, sim, grande sabedoria intelectual, mas que sob a perspectiva teológica não bastou para que seus espíritos subissem aos céus do Paraíso. O mesmo Virgílio menciona, em outro momento da Comédia, o motivo da sua própria condenação, colocando-se ao lado daqueles filósofos antigos: Io son Virgilio; e per null'altro rio / lo ciel perdei che per non aver fé. ${ }^{81}$ (Purg. VII 7-8).

Consideradas as semelhanças entre Ulisses e os sábios antigos, a grande diferença entre eles, além de seus crimes de fraude, seria a desobediência do herói grego em relação aos limites do seu conhecimento, o seu trapassar del segno ${ }^{82}$. E, se vista a maneira mencionada com a qual Santo Agostinho mostra suas fraquezas diante da gula (Confissões X XXXI 47), a intemperança gulosa pode ser condenável pela falta de destino do alimento, já que o que se

\footnotetext{
80، Ó gente humana! Que te baste o quia! / Pois se tivesses tudo penetrado / mister não fora o parto de Maria! / Viste tentá-lo, mas sem resultado, / aqueles que no Limbo expiarão, / eternamente, o seu desejo ousado. / De Aristóteles falo e de Platão, / e de outros mais.' E a face, tristemente, / pendeu, calado, presa da emoção." Ibid., pp.362-4, grifo do autor.

81 “ 'Eu sou Virgílio; e se não pude um dia / ao céu alçar-me foi por não ter fé, / e não por culpas graves' - disse o guia." Ibid., p.392.

82 "a desobediência." (Par. XXVI 115-7) Ibid., p. 764.
} 
come em excesso é acumulado e não aproveitado. Seria essa a mesma linha de raciocínio que se vê em Dante quando o poeta condena uma espécie de incontinência por conhecimento do herói Ulisses - "semelhante a Zeus grande no intelecto" (Il. X 138). O herói parte em uma viagem em busca de virtude e conhecimento, mas um conhecimento não aplicável a nenhum bem maior pela sua falta de fé.

Assim como em Dante, não foram poucas as versões sobre a morte de Ulisses ao longo da literatura, a exemplo de Cícero (De Finibus V XVIII 48) ou de Sêneca (Epístola 88 7), que o viam como desejoso de conhecer o oceano adentro. Partindo de uma tradição literária que encontra brechas nas já citadas palavras de Tirésias (Od. XI 134) sobre a morte de Ulisses, é possível de se imaginar que Dante tenha procurado ilustrar com a figura do herói mais um exemplo de imprudência e intemperança. Principalmente, porque, segundo o maior dos filósofos para o poeta, o autocontrole e a firmeza são disposições louváveis, sendo o indivíduo que age com desregramento ciente da gravidade de suas ações; segundo Aristóteles (EN 1145b 8-15), o homem possuidor de autocontrole prefere dar ouvidos à razão quando vê seus desejos em desacordo com seus valores.

O Ulisses dantesco naufragou junto aos companheiros por uma vontade superior à sua - do mesmo modo como Dante inicia a sua caminhada por aquelas terras proibidas ao grego: como a outro alguém agradou (com'altrui piacque. Inf. XXVI 141 / Purg. I 133) -, denotando que nessa viagem havia algo de vetado e completando a ideia de proibição de ter ultrapassado as colunas de Hércules ${ }^{83}$, colocadas na entrada do oceano como um limite aos navegadores antigos (acciò che l'uom più oltre non si metta. Inf. XXVI 109). O momento em que o herói narra a sua morte e a dos seus companheiros ganha importância central no Canto, que se conclui nessa grande tensão, em detrimento da sua proposta inicial de discutir a fraude.

\footnotetext{
${ }^{83}$ Filho de Zeus que, depois de cumprir um dos seus doze trabalhos como semideus, deixou uma lembrança de sua passagem pela Líbia ao erguer os rochedos de Ceuta e de Gibraltar, estabelecendo um limite para a navegação do mundo antigo (GRIMAL, 1997, p. 211).
} 
Quando Dante se depara com chamas incandescentes no oitavo círculo de Malebolge, é nítida a curiosidade do poeta em descobrir a culpa que ali é punida (Inf. XXVI 43-5). Mas a grande força narrativa do Canto começa um pouco antes disso, quando ele se dá conta que terá de explicitar o que ocorreu na sua passagem por aquela câmara infernal: (Allor mi dolsi, e ora mi ridoglio... Inf. XXVI 19-24). A mencionada força narrativa vem de uma clara consciência que Dante tem de que, nesse momento, o mais importante é saber conduzir a mente com prudência (e più lo 'ngegno affreno ch 'i' non soglio, / perché non corra che virtù nol guidi Inf. XXVI 21-2), para que não incorra no mesmo erro daquele que, como ele nos explicitará, encontrou a sua punição dentro de uma língua de fogo. É de se considerar que para o poeta, nem mesmo o uso do intelecto pode ser feito de forma incondicional; deve ser guiado pela virtude e pela prudência para que dele seja feito um bom emprego. Tem-se no texto:

Io stava sovra 'l ponte a veder surto, Sì che s'io non avessi un ronchion preso, caduto sarei giù sanz'esser urto. ${ }^{84}$ (Inf. XXVI 43-5)

Existe, nesse momento, uma espécie de auto-repreensão por parte do poeta narrador quando se dá conta de que a sua curiosidade em descobrir o que se passava no fundo do círculo quase fez com que ele mesmo caísse lá onde estão os punidos, igualando-se a eles de algum modo. Nessa auto-repreensão, Chiavacci Leonardi (2005, Inf., p. 770) vê uma grande influência do pensamento cristão, sobretudo o tomístico já dominado por considerações aristotélicas, quando prega que a sabedoria humana não pode presumir o fato de ser ilimitada a risco de tudo perder, sendo necessário ao homem "frear o apetite da vontade de

\footnotetext{
84 "E chegara, na ponte, tanto ao lado, / para olhar, que se não travasse a mão / a uma rocha, teria escorregado." Ibid., p. 268.
} 
conhecimento" ${ }^{85}$. Mattalia (1975, p. 94), também nessa direção, observa que na exaltação dantesca do filósofo Aristóteles se reflete a concepção escolástica do saber como um sistema enciclopedicamente vasto, mas fechado.

Também é explícito esse ponto de vista de Dante em outro momento (Conv. IV XXI 14), fazendo crer que ao homem prudente e de reto caráter é um bem saber refrear as suas paixões, citando Santo Agostinho e mais uma vez Aristóteles no segundo livro da sua Ética. É quando o poeta compara a vontade humana a um nobre cavalo (Conv. IV XXVI 6), que precisa estar em boas mãos e ser guiado pelos freios e esporas de um bom cavaleiro (a razão) para que se mantenha bem conduzido. A intensidade do olhar de Dante - aquela que o induz a tanta exposição e o faria cair se não estivesse agarrado à rocha - comprova ser esse o momento introduzido com ânsia pelos versos 19-24 já mencionados do mesmo Canto. Ali, vemos um poeta tão consciente que o peregrino encarnado por ele se encontra em estado de impaciência que arrisca a queda no precipício da fossa infernal, aquela onde se encontra Ulisses, “o incansável defensor do humano saber” (DOTTI, 1996, p. 66). É nesse momento que o seu guia Virgílio o alerta para a importância dos punidos dentro da chama num tom altamente respeitoso (Inf. XXVI 55-60).

Segundo o poeta, que clama ardentemente por poder ouvir do próprio condenado a razão de sua ruína e o momento de sua morte ("maestro, assai ten priego / e ripriego, che 'l priego vaglia mille / (...) vedi che del disio ver' lei mi piego!" ${ }^{86}$ Inf. XXVI 65-6 / 69), Ulisses foi movido por uma insaciável sede de conhecimento que o levou a induzir seus companheiros de navegação a seguir em busca de experiências; experiências essas que os levaram a entrever a montanha do paraíso terrestre, proibida aos vivos, como viria o poeta a

\footnotetext{
85 "Sic oportet ut homo laudabiliter huiusmodi appetitum [veritatem cognoscendi] refrenet, ne immoderate rerum cognitioni intendat" (Suma Teológica, II, IIae, q166 a2 ad3).

86 "mestre, eu te peço instantemente / e mil vezes voltara a suplicar (...) / escutá-los desejo ardentemente". Ibid., p. 270, grifo meu.
} 
saber quando ele mesmo ali chegou (Venimmo poi in sul lito diserto, / che mai non vide navicar sue acque / omo, che di tornar sia poscia esperto. ${ }^{87}$ Purg. I 130-2).

“O frati,” dissi, “che per cento milia
perigli siete giunti a l'occidente,
a questa tanto picciola vigilia
d'i nostri sensi ch'è del rimanente
non vogliate negar l'esperïenza,
di retro al sol, del mondo sanza gente.
Considerate la vostra semenza:
fatti non foste a viver come bruti,
ma per seguir virtute e canoscenza." 88
(Inf. XXVI 112-20)

Temos aqui mais um belo exemplo da forte retórica de Ulisses em ação. Inicialmente, (1) por invocar seus amigos tendo em vista todos os perigos que eles já teriam superado juntos, reafirmando a maneira como se dirige a eles: “Ó irmãos!”; depois (2), por chamar a atenção de seus companheiros para o curto tempo de vida que lhes restava, sendo eles já avançados na idade, como se considerasse que pouco ou nada teriam a perder; e (3) como um gran finale, invocando a verdadeira natureza do homem, a qual os companheiros não poderiam ignorar, feita para buscar a virtude e o conhecimento. Segundo Fubini (1963, p. 9), não é possível encontrar nesse preâmbulo ao episódio um único eco que destoe do tom respeitoso que iremos presenciar durante o episódio em si, do qual esse preâmbulo funciona como um pedestal; não é possível encontrar ali nada que permita supor no poeta um sentimento em direção ao seu herói que não seja o de admiração, apesar de a cena se localizar no Inferno.

\footnotetext{
87 "Fomos pelo areal amplo e saliente, / nunca decerto até ali calcado / por alguém de regresso experiente." Ibid., p. 352.

88 “- Ó irmãos (eu falei), que desta feita / aos confins avançastes do Ocidente, / entre perigos, onde o sol se deita, / à pouca vida em vós remanescente / não recuseis a esplêndida experiência / do mundo ermo e ignorado à nossa frente. / Relembrai vossa origem, vossa essência: / criados não fostes como animais, / mas donos de vontade e consciência -." Ibid., p. 271. É indispensável observar que a tradução de Martins não valoriza o último verso da citação, onde é ressaltada por Dante a natural inclinação do homem para buscar "virtude e conhecimento", informação essencial para a discussão deste trabalho.
} 
Isso é perfeitamente compreensível se considerados os princípios do poeta, que considera a busca pela virtude digna e própria da alma racional (Conv. III VII 8). Desse modo, afirma Pietrobono (1946 [1924-30]), Inf. XXVI 120) “aquilo que Ulisses propõe aos seus companheiros não é nada além do que o objetivo final, é a última perfeição à qual o homem tende naturalmente"; ou como coloca Fubini (1963, p. 14), "é a lei de toda a humanidade". Ainda segundo esse último comentador, o discurso (orazion picciola) que Ulisses usou para convencer seus companheiros fez "ferver o espírtio de Dante do tempo do Convivio", pois ali está empregada toda a nobre essência da natureza humana que o poeta descreveu como "amante da verdade e da virtude" (ha l'uomo amore alla veritade e alla vertude. Conv. III III 11); natureza que o conteúdo de seu tratado filosófico tem a intenção prioritária de conduzir ao conhecimento e à virtude (massimamente intende inducere li uomini a scienza e a vertù. Conv. I IX 7)

Segundo Mattalia (1975, pp. 529-30), a palavra semenza (v. 118) do discurso que Ulisses dirige aos seus companheiros - denotada como semente ou origem - estreita uma conexão privilegiada entre o Criador e o homem, a quem foi oferecido o dom da alma racional capaz de virtude e conhecimento (virtute e canoscenza v. 120) e, com isso, o dom da perfeição moral e intelectual. De acordo com ele, toda a estrofe possui um fundo bíblico com a alusão feita à criação do primeiro homem; mas superada a metáfora, a chave para o entendimento da questão paira mais uma vez no princípio capital da doutrina aristotélica, aceita fundamentalmente pela filosofia escolástica, principalmente a tomística.

Em outro momento, Mattalia (1975, p. 279) reflete sobre a natureza da alma fazendo uma grande diferenciação a respeito dos tipos de alma existentes de acordo com aquilo ao qual está ligada, entenda-se: alma vegetativa, a do reino vegetal; alma sensitiva, a dos animais em geral, que seguem os seus instintos; e alma intelectual, a dos homens, possuidora das duas naturezas anteriores, mas também desejosa de saber. Se essas diferenças forem levadas em 
conta, pode-se considerar que Ulisses foi incontinente por não saber frear a sua vontade de conhecimento, natural em sua origem, mas exagerada no herói. Isso porque se imagina que o que diferencia o homem dos outros seres vivos é o fato de possuir necessidades intelectuais além das físicas. Na mesma direção segue Jacopo della Lana (1324-28, Inf. IX Nota), que afirma não ser possível considerar humano alguém sem alma racional.

Com o argumento de o homem ter procedência divina, criado para buscar virtude e conhecimento, o herói convence aqueles com quem dividia o pão a conquistar mais sustento, dessa vez para as faculdades do espírito. De acordo com Dante, Ulisses - que por um impulso em querer visitar para além do que fora estabelecido pela tradição de seu povo como um limite - convenceu seus fiéis parceiros a adentrar no oceano e apropriar-se indevidamente de um conhecimento que a eles não estava permitido. Vale lembrar que na Ilíada (XIV 201), o oceano é mostrado como o princípio dos deuses (theon genesis), o mesmo lugar para onde o herói agora quer rumar. No entanto, Chiavacci Leonardi (2005, Inf., p. 786) considera o discurso de Ulisses direcionado apenas a ele mesmo, no qual os companheiros do herói são apenas figuras; segundo a comentadora, "apenas Ulisses se encontrava frente à grande escolha".

Entretanto, são outros versos que precedem a orazion picciola que chamam a atenção de Dante à consciência que Ulisses tem de sua própria personalidade, manifestada no comportamento intencional do herói ao agir, mesmo em conflito, com os princípios que na Odisséia o fizeram voltar para casa. Nesse sentido, a ideia ancestral de erro denotada pelo termo acrasia - base para concepção de incontinência, visto que se trata do termo grego para a questão - se expressa plenamente. De acordo com Audi (2006, p. 13-4), a acrasia se manifesta principalmente se considerada a relação com "a clareza de seus limites e a capacidade de discernimento sobre as próprias ações". Vê-se também no dicionário eletrônico Houaiss da língua portuguesa (2001), a acrasia definida como uma "fraqueza de vontade, 
uma condição de quem, apesar de saber o melhor a ser feito, faz outra coisa". Segundo Mora (2000, p. 46), “o 'ácrata' (...) não tem poder sobre coisa alguma, especialmente sobre si mesmo" e, com isso, "torna-se incapaz de dominar-se". Seria esse o motivo, de acordo com ele, para que a acrasia tenha sido equiparada à incontinência.

\author{
Né dolcezza di figlio, né la pieta \\ del vecchio padre, né 'l debito amore \\ lo qual dovea Penelopè far lieta, \\ vincer potero dentro a me l'ardore \\ ch' $i$ ' ebbi a divenir del mondo esperto \\ e de li vizi umani e del valore; \\ ma misi me per l'alto mare aperto \\ sol con un legno e con quella compagna \\ picciola da la qual non fui diserto. ${ }^{89}$ \\ (Inf. XXVI 94-102, grifo meu)
}

Consciência de seus impedimentos físicos e emocionais não faltou ao herói. Com isso, ele torna-se imprudente por não conter uma vontade legítima (como a de alimento), mas não considerando os limites que ele próprio conhecia, caracterizando um tipo de incontinência. Em Ciotti (1996, p. 417), os pecadores condenados pelo crime da incontinência "apresentam uma presença de humanidade altamente significativa e singularmente expressiva em virtude da eficácia da figuração poética", o que Dante transparece pela consciência ética perceptiva e sensível dos seus cânones clássicos e escolásticos. Para Chiavacci Leonardi (2005, Inf., p. 783), a ansiedade de Ulisses em ter a experiência da natureza física (del mondo v.98) e da moral (de li vizi... e del valore v.99) é recuperada por Dante tendo ele como base o modelo grego e o seu próprio estilo de vida como grande estudioso e pesquisador, mas completamente influenciado pelo pensamento tomístico de que o intelecto humano não pode presumir ser ilimitado a risco de tudo perder.

\footnotetext{
89 "Nem de meu filho o olhar, nem a extremada / velhice de meu pai, nem mesmo o amor / de Penélope ansiosa e apaixonada, / nada pôde abater o meu pendor / de ir pelo mundo, em longo aprendizado, / dos homens perquirindo o erro e o valor. / Lancei-me ao mar, em lenho delicado, / junto à pequena e fraternal companha / pela qual nunca fui abandonado.” Ibid., p. 271, grifo meu.
} 
De acordo com Mattalia (1975, p. 149) e seguindo as palavras de Ulisses quando o herói se dá conta de querer seguir a virtude e o conhecimento (Inf. XXVI 120), os atributos fundamentais do ser humano são a alma e o corpo na sua união orgânica e individual, aos quais sendo o homem racional, são unidos os atributos da perfeição moral e intelectual.

Nesse sentido, a importância de Ulisses para a civilização ocidental tem a ver com os modelos que a cultura européia construiu desde os primórdios, a partir da literatura, para a imagem de homem. Como diz Boitani (1992, p. 23), “a presença constante dessa figura [de Ulisses] e o fascínio que ela nunca deixou de exercer na imaginação são sinais de que ela carrega consigo o nosso destino de homem".

Segundo Auerbach (2008, p. 137), é na narrativa dantesca que se vê o nascimento de uma concordância entre o espírito de descoberta dos antigos e dos modernos, fundamentada na figura da personagem Ulisses. Reconhece-se no herói uma busca pela sabedoria justificada em Aristóteles, que supõe o conhecimento entre as coisas mais valiosas e belas ( $D A$ 402a1). Dante admite ter essa visão logo nas primeiras linhas do Convivio, como também citado anteriormente; porém, para o poeta, seguindo a perspectiva da tradição filosófica, se o conhecimento não pode conduzir a um bem, não pode engrandecer a alma.

O Ulisses dantesco segue a vontade de querer descobrir os mistérios do proibido, passando por cima de sentimentos mais nobres representados pelo amor do velho pai Laertes, do filho Telêmaco e da esposa Penélope. O desejo do laértida, de deparar-se com um hemisfério desconhecido e com a montanha do paraíso terrestre (Inf. XXVI 99) - apresentada como aquela que reflete o valor dos homens e dos seus vícios - é mais importante que os sentimentos nobres representados pelo amor familiar.

Contudo, a fraude, crime pelo qual é punido Ulisses no oitavo círculo do Inferno, seria entendida como um erro de pura malícia que opera a partir de uma escolha, na qual o juízo do agente já se encontra pervertido. Em contraposição a isso, destaca-se o erro por incontinência, 
provado por uma ação impulsionada pela paixão (EN 1145b 10-15). Assim, observa-se uma clara influência do filósofo grego na Escolástica, principalmente em São Tomás de Aquino, que considera "paixão" toda a sorte de movimentos do apetite sensível (Suma Teológica I II q.35 a.1). Nesse sentido, mais que com intenção de prejudicar e condenar seus companheiros à morte, emerge um Ulisses movido pelo impulso da paixão de conhecimento que faz com que ele parta, obviamente não sem companhia, para além das colunas de Hércules.

A incontinência de Ulisses, portanto, se realizaria pelo fato de ele não se conter diante da possibilidade de se apropriar de algo que não estava autorizado a possuir. Assim como o guloso Ciacco ignorou os limites do corpo e foi condenado, o herói ignorou os limites de sua mente sedenta de conhecimento e condenou a si e aos seus companheiros. Além disso, Ulisses não foi chamado a conhecer o oculto, assim como o fora Dante ao ser convidado a cumprir a viagem: A le quai poi se tu vorrai salire ${ }^{90}$ (Inf. I 121, grifo meu). Impelido pela vontade de querer descobrir o que fora estabelecido pela tradição de seu povo como um limite do conhecimento, o laértida ultrapassou premeditadamente as colunas de Hércules para navegar oceano afora. Segundo Boitani (1992, p. 46), o herói não poderia concluir que voltassem vivos de tal viagem por serem todos vecchi e tardi, o que Dante nos mostra como uma espécie de presunção ao ignorar as suas restrições.

Io e ' compagni eravam vecchi e tardi quando venimmo a quella foce stretta dov' Ercule segnò li suoi riguardi acciò che l'uom più oltre non si metta; da la man destra mi lasciai Sibilia, da l'altra già m'avea lasciata Setta. ${ }^{91}$ (Inf. XXVI 106-11, grifo meu)

\footnotetext{
90 "Se lá subir quiseres". Trad. XAVIER PINHEIRO, 1958, p. 11, grifo meu. Palavras de Virgílio que se referem ao Paraíso, quando o poeta latino apresenta o roteiro da viagem a Dante.

91 "Já bem mais velhos éramos e tardos, / quando à barra chegamos apertada, / onde Hércules depôs um de seus fardos, / sinal para não ser ultrapassada: / ficou Sevilha atrás, pela direita, / e foi, à esquerda, Ceuta ladeada." Ibid., p. 271, grifo meu.
} 
Se tais versos fizessem parte da tradição grega, seguramente Ulisses cairia em hybris, conceito mais ancestral de injustiça, entre os gregos. Tal conceito representou de forma muito intensa as atribuições de erro no universo da religiosidade na Grécia Antiga, sobretudo naquela pré-socrática. "A hybris não nasce da falta, mas do excesso de teoria, mais exatamente da inadequação entre a teoria e a prática" (AUEBENQUE, 2003, p. 9). Para que a hybris se concretize é necessário que se aja erradamente, mas tendo consciência das suas limitações como homem; nesse sentido, entende-se uma total consciência por parte de Ulisses quando cita a barreira representada pelos símbolos de Hércules.

O desejo de conhecer presente no herói dantesco o levou à ruína, corrompendo o sentido original da visão que é perceber a realidade. $\mathrm{O}$ ardor que se apresenta nele pode ser lido como uma cobiça dos olhos, que não quer perceber a realidade, mas apenas entregar-se a uma vontade. Santo Agostinho conclui que a ânsia por comer presente nos gulosos não almeja a saciedade, mas sim comer e saborear (Confissões X XXXI 47), o que se pode aplicar à curiositas e à cobiça dos olhos. Tem-se que 'a preocupação deste tipo de 'ver' não é a de aprender e, fazendo-o, penetrar na verdade, mas de abandonar-se ao mundo" (PIEPER, 1970, pp. 280-2); com isso, o prazer em buscar aquilo que nos faz feliz ou nos completa também possui um limite se estiver em desacordo com outros princípios.

Buscando mais uma vez explicação nos mestres de Dante, existe em Aristóteles uma distinção entre dois tipos de virtude do intelecto, a sabedoria teórica, chamada sophia, e a sabedoria prática, ou phronesis. Para o filósofo, a primeira é necessária para a felicidade do homem por ser uma das partes que a compõem, enquanto que a segunda é imprescindível para a aplicação do agente produtivo, indispensável para a vida em sociedade (ALLAN, 1970, p. 152); mas, segundo o próprio filósofo, a segunda só pode estar presente se soubermos agir com prudência (EN 1145 a2-4). E não é exatamente com prudência que o Ulisses dantesco descreve a partida para a sua viagem: 


\begin{abstract}
Li miei compagni fec' io sì aguti, con questa orazion picciola, al cammino, che a pena poscia li avrei ritenuti; e volta nostra poppa nel mattino, de' remi facemmo ali al folle volo, sempre acquistando dal lato mancino. ${ }^{92}$ (Inf. XXVI 121-6)
\end{abstract}

Talvez seja o caso de considerar esse passo inconsequente (folle volo) de Ulisses como um momento de sua vida no qual não mais havia a preocupação em ser o rei de Ítaca, servindo ao seu povo e à sua família, e vê-lo como desejoso por conhecimento para a sua própria felicidade baseado naquilo que mais sabia fazer: vagar pelo mundo. Para Allan (1970, p. 158), Aristóteles não defendia o livre-arbítrio, mas considerava que o homem é muitas vezes conduzido por velhos hábitos e inclinações hereditárias adquiridas, sobre os quais perde o controle. E aí está a incontinência, segundo o próprio Dante, se considerado o trecho do Convivio em que o autor menciona o caráter habitual desse tipo de erro, onde a culpa está em repetir costumes que se encontram em desconformidade com a justa medida (Conv. III VIII 17). Seria essa uma possível maneira de entender a condenação de Ulisses, mas principalmente de enxergar o motivo da citada digressão de Dante nesse Canto, ao tratar de um crime que vai muito além da fraude.

Entre Ulisses e Dante se encontra Virgílio, que com uma altivez retórica introduz o grego ao florentino não apenas na ação da cena infernal. Contudo, apesar de ter em Virgílio seu grande modelo estético ( $D V E$ II IV 5-8), o poeta talvez não compactuasse completamente com a forma que o herói fora representado pelo poeta latino, como o "de todo mal o inventor" (En. II 163), vendo nele um quê de dignidade, mesmo que imprudente. Como afirma Fubini, existe uma espécie de dissídio entre o Dante teólogo que condena Ulisses pela sua falta de freio e o Dante poeta que admira a vontade de saber do herói. E dessa disputa, segundo ele,

\footnotetext{
92 "Aos companheiros, com palavras tais, / instilei tanto o gosto da jornada, / que nem eu mesmo os reteria mais. / A popa à parte matinal voltada, / demos com força aos remos, e cingindo / à esquerda a rota, fomos de longada.” Ibid., pp. 271-2.
} 
sairia vitorioso o poeta "que admira e celebra, na loucura de ultrapassar os limites do conhecível, o vigoroso e generoso operar do espírito humano" (ROSSI, 1923, p. 332 apud Fubini 1963, p. 10).

Mas nem mesmo a sabedoria que tanto foi ressaltada como uma das virtudes do herói lhe foi suficiente no momento de dosar-lhe a curiosidade, faltando-lhe certamente prudência. Para Aristóteles (EN 1145a 2-4), a prudência é fundamental para que outras virtudes se consolidem; teria ela a função de agir como uma conectora entre as virtudes morais características de um homem bom e justo, explicando que se um homem possuir a única e mais importante virtude da prudência terá todas as outras virtudes morais.

Diferentemente do que foi proposto para ilustrar a condenação de outros punidos em outros círculos, para os fraudulentos não é usada a figura vegetal como para os suicidas (Inf. XIII 15), nem a animal como para os ladrões (Inf. XXV 50), mas sim a do elemento fogo e o seu incansável movimento em direção ao alto ${ }^{93}$. E é para o alto que o poeta nos conduz já no início do Canto de Ulisses, com a referência ao arrebatamento divino de Elias (Inf. XXVI 349/ BÍBLIA, 2003. 2Rs VI 2), quando um carro atrelado cavalos de fogo rapta o profeta e o conduz aos céus; é mais uma vez o fogo a introduzir o ardor que, como será visto nos versos seguintes, impulsionou Ulisses (Inf. XXVI 97) a buscar por mais experiência. Porém, a falta de autocontrole presente em outros pecadores, como em Ciacco, principalmente, é semelhante a que aqui se vê em Ulisses, quando ele não pode vencer esse ardor de conhecer a natureza física e a moral dos homens (Inf. XXVI 97-9), do mesmo modo que o guloso não soube conter-se diante de uma mesa farta.

Assim como Ciacco, e ao contrário de todos os outros fraudulentos da sua fossa, Ulisses não é punido solitariamente na câmara infernal. Está com ele Diomedes, seu companheiro em vida tanto na guerra de Tróia como na superação das colunas de

\footnotetext{
${ }^{93}$ Também sobre a natureza do fogo discorre Aristóteles em EN 1103a 20-5, lembrando-nos que esse elemento não possui a natureza de mover-se para baixo.
} 
Hércules. O companheiro que ironicamente reconhece em Ulisses a astúcia que os faria escapar ilesos até mesmo de chamas ardentes (Il. X 246) é aquele que o acompanha dentro da língua de fogo infernal da qual não existe escapatória. Aquela astúcia que fez com que Ulisses, junto a Diomedes, descobrisse Aquiles escondido entre as mulheres na ilha de Lemno (Achilleida I 846); ou a que o fez pegar o cetro de Agamenão e assumir a postura de comandante das tropas acaias (Il. II 186); ou ainda, em outro momento, o fez proferir brilhantes palavras para tentar convencer Aquiles a retomar os trabalhos na guerra (Il. IX 225); aquela mesma astúcia que o condenou a sofrer eternamente dentro de uma língua de fogo que bem caracteriza a sua eloquência e mantém presente o contrapasso, fazendo com que Ulisses não esqueça de como se comportou a sua própria língua.

E pensando no contrapasso ardente do herói, é interessante salientar que Aristóteles (DA 404b 30), no momento em que investiga a natureza da alma, chega a considerar que ela seja feita de fogo, "pois o fogo é composto de partículas sutis e é o mais incorpóreo dos elementos e, além disso, em sentido primordial, tanto é movido como move tudo o mais" ${ }^{94}$; derivando daí a possibilidade de considerar um ardor aquilo que naturalmente da alma surge.

\subsection{A EXTRAPOLAÇÃO DA JUSTA MEDIDA INTELECTUAL}

Sem dúvida, o pecado do Ulisses dantesco pode estar relacionado à sua fraude; o primeiro indício dessa conclusão é o fato de esse réprobo se encontrar com outros fraudulentos. De fato, como afirma Fubini (1963, p. 11), não foi pelo folle volo que Ulisses foi condenado à oitava vala infernal, mas sim pelas famosas fraudes, explicitamente lembradas por Virgílio quando da introdução do grego na cena do Inferno. Todavia, é o

\footnotetext{
${ }^{94}$ Trad. REIS, 2006, p. 52.
} 
próprio crítico a reconhecer que Dante lembra apenas as culpas que menos diminuem o seu herói entre aquelas tradicionais de Ulisses, afirmando que nenhum outro episódio dantesco possui um preâmbulo tão longo quanto esse. Nesse momento, ele adverte: “o leitor é gradualmente conduzido a um mundo que não mais àquele infernal e preparado a ouvir as palavras de um espírito nobre (...), um grande solitário de Malebolge” (1963, pp. 7-8).

A análise e a tentativa de aproximação, que aqui se faz no sentido de enquadrar o herói como um incontinente, é porque no seu relato em primeira pessoa não se tem o indício de fraude, e sim de uma falta de prudência - a mesma virtude que deveria conduzir o poeta Dante, como visto no início do canto - ao não se conter diante de um limite. Tratava-se, sim, o herói de um grande virtuoso, se consideradas as virtudes particulares das quais fala Aristóteles (EN III-V) como a coragem, a generosidade, a veracidade, a ambição e o desapego, entre outras; porém, da virtude da prudência, dessa o Ulisses dantesco não dispunha, visto que não considerou a inconsequência do seu ato:

\section{Matto è chi spera che nostra ragione possa trascorrer la infinita via che tiene una sustanza in tre persone. ${ }^{95}$ (Purg. III 34-6)}

No início do poema, Dante usa o adjetivo louco (folle) ao sentir medo da imprudência que poderia estar por fazer, ao aceitar o convite do antigo espírito Virgílio a adentrar no mundo não permitido aos vivos (Per che, se del venire io m'abbandono, / temo che la venuta non sia folle ${ }^{96}$. Inf. II 34-5, grifo meu). Do mesmo modo, no trecho citado acima, segundo o poeta, louco (matto) é quem presume que a razão humana possa atingir a infinita complexidade da divindade. A mesma ideia é empregada quando o poeta descreve a travessia de Ulisses, que, junto aos seus companheiros, dos remos do barco fizeram asas a esse insano

\footnotetext{
95 "E é vão supor que nossa inteligência / possa abranger a sempiterna via / das três pessoas numa só essência." Ibid., p. 362.

96 "Receio que empreender um tal destino, / na minha pequenez, é uma loucura." Ibid., p. 88, grifo meu.
} 
voo (de' remi facemmo ali al folle volo ${ }^{97}$. Inf. XXVI 125, grifo meu); bem como no momento em que Dante e a sua guia Beatriz sobem ao Primeiro Móvel e de lá avistam o planeta Terra, fazendo referência ao seu imenso oceano através da louca aventura do herói Ulisses (il varco folle d'Ulisse ${ }^{98}$. Par. XXVII 83, grifo meu).

No Inferno, Ulisses rumou a caminho do Oeste e ultrapassou as colunas de Hércules, ou seja, o Estreito de Gibraltar, seguindo em direção ao sol poente (di retro al sol. Inf. XXVI 117) e contrariando as forças da natureza em não querer se privar da luz solar; cabe lembrar que a ideia de luz, sobretudo a divina, é o principal referencial simbólico para a noção de virtude e sabedoria. Por outro lado, Boitani (1992, p. 24) ressalta que no contexto da língua grega da qual faz parte a personagem em questão, a palavra zophos pode significar tanto "obscuridade" quanto "ocidente". Isso assume grande importância, principalmente se forem lembrados alguns versos de Homero (Od. XI 1-22), quando o herói também parte para o ocidente tendo como destino o hades, reino dos mortos.

Metaforicamente [...], navegar para além de Gibraltar significa extrapolar um limite ontológico, ultrapassar um limite determinado ao homem, em direção à escuridão transnatural. Eis, portanto, estabelecidas as fronteiras ao impacto da consciência e da vida, as duas árvores proibidas à humanidade no Jardim do Éden, no oriente. ${ }^{99}$ (BOITANI, 1992, p. 25)

Para Aristóteles (EN 1104b 20-5), não se pode negar que haja no homem uma espécie de resistência ao princípio racional, que o faz seguir em busca de sentimentos que podem ser equívocos, sendo o caso de Ulisses quando afirma ter consciência do valor dos sentimentos de sua gente. Em Dante, essa resistência é manifestada pelas palavras de Marco Lombardo quando da explicação sobre o livre arbítrio:

\footnotetext{
97 “Asas os remos são na empresa ousada." Trad. XAVIER PINHEIRO, 1958, p. 121. Apesar de ser a tradução em que esse verso mais se aproxima do original, a ideia de loucura não está impressa, mas sim a de ousadia.

98 “A passagem que Ulisses aventureiro (...) tentou.” Trad. XAVIER PINHEIRO, 1958,p. 335.

${ }^{99}$ Tradução minha de: "Metaforicamente [...], navigare oltre Gibilterra significa varcare una soglia ontologica, oltrepassare il limite (peras) assegnato all'uomo, in direzione di una tenebra trasnaturale. Ecco dunque stabiliti $i$ confini ad un colpo della conoscenza e della vita, $i$ due alberi proibiti all'umanità nel giardino dell'Eden, a oriente." Op. cit., p. 25.
} 


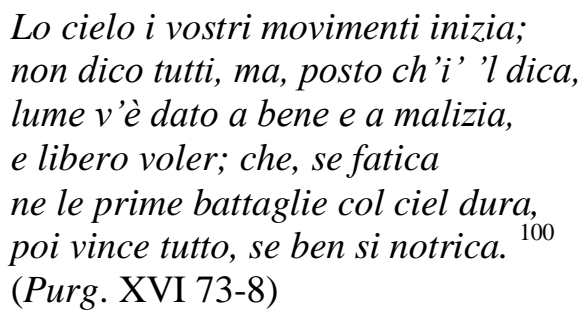

Em tais versos, a personagem explica a origem divina dos movimentos humanos, cabendo ao homem - a quem é dada a faculdade de saber sobre o bem e o mal, bem como a possibilidade de escolha - saber direcionar esses movimentos. É ressaltado, contudo, que nem todos os movimentos são impulsionados pela divindade; aqueles que podem ser considerados costumeiros podem já estar corrompidos, de certa forma, pela falta de freio no momento da escolha, encaixando-se aqui a intemperança e a sua caracterização de "vício habitual" (vizii consuetudinarii [...] sì come la intemperanza. Conv. III VIII 17). Note-se, além disso, a necessidade de "bem se nutrir" (se ben si notrica. Purg. XVI 78), denotada apenas no texto original e não na tradução apresentada em nota.

Aqui é presente a imagem do pecado original e de suas relações com o que está sendo estudado. Sabe-se que tal pecado consistiu na extrapolação de um limite imposto por Deus, nesse caso o do Antigo Testamento Bíblico. Eva sucumbiu à curiosidade provocada pela serpente e comeu o único fruto proibido do Éden para ter acesso a um conhecimento vetado aos homens.

Por mais que o poeta Dante explicite na voz de Adão que não foi o ato de comer a maçã o motivo da condenação dos primeiros homens, é quase inevitável a associação desse ato com a incontinência alimentar por ele se tratar de um exagero e se realizar através da boca. Tal ato pode ser lido menos como intemperante no sentido físico, pela não-necessidade em alimentar-se de tal fruto, visto que existiam vários outros no vasto pomar do paraíso

100 "O céu os vossos atos inicia, / não direi todos, mas se assim fizesse, / dada vos foi a luz que aponta a via. / Quem contra o mal, seguro, se enrijece, / e a luta adentra, de consciência dina, / acaba por vencer e não perece." Ibid., p. 462. 
terrestre; mas principalmente como um ato incontinente no sentido intelectual, porque ter a faculdade de "ser como Deus, conhecendo o bem e o mal" (BÍBLIA, 2003. Gn 3 5) ia além das necessidades daqueles que viviam em perfeita harmonia no paraíso pré-cristão, violando uma proibição evidente.

\author{
Or, figliuol mio, non il gustar del legno \\ fu per sé la cagion di tanto essilio, \\ ma solamente il trapassar del segno. ${ }^{101}$ \\ (Par. XXVI 115-7)
}

Nas ações humanas, a concepção de justa medida equivale à moderação e à temperança, ou seja, às virtudes que se contrapõem ao excesso. E para que seja possível um distanciamento do exagero, faz-se necessário que os homens controlem os seus impulsos desejosos através da razão, aquela mesma que na visão teológica deve nos impulsionar a Deus. Porém, o que acontece tanto no episódio bíblico como na narrativa de Dante é a razão sendo usada para uma aproximação indevida a Deus, quando se quer possuir um conhecimento vetado. Conhecimento que o próprio poeta reconhece, no início do poema, como um "alto passo" (Inf. II 12), que para ser dado é necessário mais do que uma simples vontade do agente; o mesmo "alto passo" no qual Ulisses confessou ter entrado ao ultrapassar as colunas de Hércules (Inf. XXVI 132).

Segundo Mattalia (1975, p. 526), existe no gesto do herói Ulisses, ao extrapolar um velho limite, "um sinal de transgressão que lembra o pecado de Adão e Eva" ${ }^{102}$. Para esse comentador, "o oceano é a franja do mistério que envolve o mundo terreno, e para sondá-lo, o homem pagão possui apenas a luz insuficiente da razão”. Razão detentora de um poder no qual Ulisses depositou uma indomável confiança; uma razão fechada nos seus próprios limites e nos limites de uma sociedade antiga baseada na ética. Contudo, para o comentador, "uma

\footnotetext{
101 "Não foi tão só, meu filho, a complacência / ao fruto a causa de meu longo exílio, / como se diz, mas a desobediência." Ibid., p. 764.

${ }^{102}$ Cf. Nardi, 1990, pp. 131-2.
} 
razão baseada na ética e com fundamento exclusivamente racional, sendo insuficiente a guiar o homem na conquista do seu último fim, ou seja, Deus".

Tanto na descrição do primeiro pecado, como nos versos analisados sobre o pecado de Ulisses, existe a ideia de uma extrapolação da citada justa medida, vista como uma falta de autocontrole. A curiosidade e a falta de prudência ao conhecer as fronteiras intocáveis e, mesmo assim, ultrapassá-las fizeram Ulisses incorrer em um ato incontinente pelo fato de o herói não saber respeitar os seus limites. É de se atentar, no entanto, que toda tradição filosófica considera inerente ao ser humano saber julgar os seus próprios atos, saber distinguir entre o bem e o mal, entre o justo e o injusto. Apesar disso, para o mundo cristão de Dante, tal capacidade não basta para que haja a salvação daquele homem que soube avaliar sua conduta. É preciso que haja o arrependimento sincero e a vontade de ser salvo por um Deus, cuja existência Ulisses ignorava. Claro que só o fato de ser pagão já faz com que Ulisses não possa ser salvo, mas basta lembrar-se das almas valorosas que se encontram na antecâmara do reino dos mortos (Inf. IV) para concluir que existe algum tipo de reconhecimento por parte de Dante àqueles que ignoravam o Deus cristão, mas que sabiam frear as suas vontades indevidas.

No contexto cultural no qual foi escrita a Comédia, a racionalidade era entendida pelo prisma da cristandade, segundo a qual para estar de acordo com aquilo que se concebia como verdade era necessário entender o mundo como uma criação única e exclusivamente divina, estando a natureza e tudo o que nela se insere subordinados à vontade de Deus. Nesse sentido, Le Goff (2005, p. 80) observa como no ano de 1277 o bispo de Paris, Étienne Tempier, condenou o uso exagerado da razão na teologia. Para isso, acreditar na Bíblia e parafrasear preceitos bíblicos era essencial.

Esse primado de ato de confiança produz uma oposição duradoura entre a fé e o saber, apoiada nas formulações de São Paulo, incessantemente repetidas 
e glosadas ao longo da Idade Média: a verdade divina só se deixa conhecer "através de um espelho", através de "enigmas". (BOUREAU, 2002, p. 413)

Da mesma maneira, diz o poeta:

Dunque vostra veduta, che convene
essere alcun de' raggi de la mente
di che tutte le cose son ripiene,
non pò da sua natura esser possente
tanto, che suo principio non discerna
molto di là da quel che l'è parvente.
Però ne la giustizia sempiterna
la vista che riceve il vostro mondo,
com'occhio per lo mare, entro s'interna;
che, ben che da la proda veggia il fondo,
in pelago nol vede; e nondimeno
èli, ma cela lui l'esser profondo.
(Par. XIX $52-63)$

Como observa Chiavacci Leonardi em referência aos versos citados (2005, Par., pp. 533-4), Deus se revela ao homem por meio das coisas sensíveis (sua criação), não podendo a mente humana avançar muito além. Esse fato é evidenciado em Dante quando ele afirma ser apenas a sabedoria capaz de revelar que o conhecimento não é o bastante para conduzir ao Deus cristão, haja vista a impossibilidade de Virgílio e de Beatriz conduzirem-no até a visão beatífica, ficando a cargo do sapientíssimo e místico São Bernardo; e a sabedoria, não necessariamente vem junto com o conhecimento.

Pelo viés dantesco, assim como pelo cristão, pode-se entender legítima a busca pelo conhecimento quando se trata de um conhecimento que conduz à sabedoria; somente esta pode ampliar a visão de mundo daquele que a procura para que toda essa racionalidade seja conduzida a um bem. Assim também faz menção a Enciclopédia Católica, no tópico destinado à noção de aspecto subjetivo de pecado, quando discorre sobre a importância em

\footnotetext{
103 "A inteligência humana, que é ligeiro / e distante reflexo assim, da mente / que abarca o mundo no seu ser inteiro, / não se pode sentir tão suficiente / que a sua própria origem não admita / mais para além de tudo o que é aparente. / E por isso a justiça alta e infinita / de Deus se mostra aos vivos em seu mundo, / como o mar à visão de quem o fita, / e que lhe vê, perto da praia, o fundo, / mas não no pélago, onde o seu velado / e recôndido leito é mais profundo. Ibid., p. 714 .
} 
adquirir conhecimento para melhor formar a consciência, estando aí o valor do homem que busca a salvação. (VANNICELLI, 1951. Tomo IX, p.1021)

Ulisses é intensamente isolado da atmosfera infernal pela sua virtude de querer conhecer, "como se representasse uma pequena chama de luminosidade na escuridão do Inferno" (INGLESE, 2002, p. 94); mas condenado por não ser capaz de respeitar os limites dos quais ele bem tinha consciência. Também Dante, como personagem de sua obra, viaja pelos mundos não permitidos aos vivos, embora se trate de uma viagem de aprendizado para a aplicação das suas crenças, como ele próprio assume a sua sede de conhecimento por estar seguro de sua fé. Tal sede é revelada explicitamente pelo poeta na subida da montanha do paraíso terrestre, mas escondida do seu guia Virgílio pelo medo que o viajante curioso teve em perguntar demais:

e io, cui nova sete ancor frugava,

di fuor tacea, e dentro dicea: 'Forse

lo troppo dimandar ch 'io fo li grava'. ${ }^{104}$

(Purg. XVIII 4, grifo meu)

[...] às vezes, é declarado que o indivíduo prudente não é capaz de ser desregrado; às vezes, que alguns indivíduos prudentes e engenhosos são desregrados [incontinentes]. ${ }^{105}$ (EN 1145b 18-20)

Segundo De Matteis (1996, p. 376), até mesmo São Tomás de Aquino precisou sufocar o seu aristotelismo e subordinar a razão à fé. Para a autora, a "sede natural" de conhecimento do religioso não foi plenamente satisfeita com a especulação filosófica, tendo que ceder à necessidade da graça divina. A mesma sede é manifestada em Dante em outro momento como um "ardor de desejo", já em vias de ser completamente saciado quando o poeta encontra-se no fim da sua viagem, na Rosa dos Beatos; aquele mesmo "ardor" que o grego não soube vencer e o impulsionou a conhecer o proibido (Inf. XXVI 95):

\footnotetext{
104،Nova sede, entretanto, me instigava; / e, calado, comigo ia pensando: / 'Meu constante inquirir quem sabe o agrava?' " Ibid., p. 471, grifo meu.

${ }^{105}$ Trad. BINI, 2007, p. 203.
} 


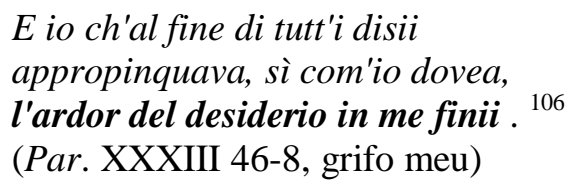

Nesse sentido, a tradição crítica tem por hábito aproximar a figura de Ulisses com a do Dante poeta, que nunca escondeu o valor que o conhecimento tinha para ele (BORGES, 1999, p. 397; MATTALIA, 1975, pp. 24/41-2). Dotti (1996, p. 26) fala em uma possível explicação para essa aproximação em uma carta que o poeta Petrarca escreve para o também escritor Boccaccio, na qual é ressaltada a falta de comedimento de Dante frente à sabedoria mesmo que isso o afastasse do amor de seus filhos e esposa, como no vestígio dos versos Inf. XXVI 43-5. Contudo, alguns anos após a concepção do episódio de Ulisses, o poeta ainda se posicionava contra a vontade exagerada de explicar o que não se revela à mente humana tão facilmente, encorajando os homens a escutar a própria voz do Criador: "Aonde eu vou, vós não podeis ir" (Et denique audiant propriam Creatoris vocem dicentis: "Quo ego vado, vos non potestis venire". Questio de aqua et terra, 77).

Virgílio, mestre e guia sempre presente ao lado de Dante na caminhada ao longo do Inferno e do Purgatório, representa o conhecimento desenvolvido no mundo antigo e tão necessário à aprendizagem do poeta peregrino na passagem pelos dois primeiros mundos do além. Ele corporifica a razão humana que caminha para a sua explicação ao longo dessa trajetória, mas reconhece o seu limite ao confiar Dante a Beatriz na ascensão ao paraíso terrestre, tendo consciência que o seu paganismo o impediria de seguir adiante. Beatriz, por sua vez, simboliza a fé e toda a sua importância como virtude teologal ao guiar o poeta pelos céus do Paraíso; essa segunda guia também é substituída antes que o poeta seja submetido à visão de Deus. É a presença de São Bernardo a afirmar ser necessário outro tipo de

\footnotetext{
106 "Eu, que da meta de minha ânsia ardente / me aproximava, então, como devia, /de todo afã me despojei à frente." Ibid., p. 810.
} 
iluminação ainda maior que a razão ou a fé para que a experiência mística do poeta se realize. Bem diferente desses modelos ideais que bem percebem os seus espaços espirituais é o Ulisses dantesco, que não só despreza os limites que bem conhecia como os desafia com a ousadia que the era peculiar no mundo grego. 


\section{CONCLUSÃO}

Ao longo desses últimos sete séculos nos quais a Comédia vem sendo lida e estudada, muito já se falou sobre a beleza da criação poética das inúmeras personagens que habitam as cantiche do poema. Isso não é diferente no caso de Ciacco e muito menos no caso de Ulisses, sendo esse último uma das personagens mais lembradas em toda a fortuna crítica de Dante. Na complexa questão que a filosofia escolástica tanto discutiu sobre o limite da razão e a oposição entre ciência e fé, o episódio que narra o fim que Dante escolheu para o herói grego passou a ocupar uma posição central no mundo das artes por resumir tão bem a questão.

Aproveitando essa rica fortuna crítica, com a presente pesquisa buscou-se pensar e analisar as personagens citadas pela incontinência, claramente o pecado de Ciacco. Para o pecado de Ulisses, muito mais controverso e debatido, objetivou-se dar uma leitura um tanto quanto provocativa da transgressão desse herói em quem a humanidade muito esteve refletida. Provocativa no sentido da visão incomum daquilo que parece estar claro ao se falar da desobediência em respeitar um limite pré-estabelecido.

Para tanto, no Capítulo 2 desta pesquisa, o conceito de incontinência foi posto em foco. Partindo dos primeiros exemplos citados por Dante para ilustrar essa categoria aristotélica acerca dos vícios humanos no Inferno, propôs-se nesse capítulo ilustrar como o poeta expressou certa compaixão por alguns tipos de incontinentes, especificamente aqueles denominados "primários" ou "próprios"; aqueles que teriam dado vazão exagerada a um instinto natural de procriação ou de alimentação. Ao contrário disso, certo desprezo foi manifestado, por parte do poeta, pelos condenados que pagavam por um apego exagerado aos bens mundanos, pelos que não souberam manifestar plenamente a sua fé, bem como por aqueles que não souberam frear seus impulsos violentos. 
Dessa primeira observação, partiu-se para uma análise mais detalhada no Capítulo 3 sobre a personagem Ciacco (Inf. VI) e todo o seu apego à alimentação. Daí surgiu um estudo sobre o pecado da gula e de como esse aspecto da incontinência "própria" está presente no pensamento do poeta, com exemplos da Comédia e do tratado filosófico Convivio; de como está presente também nas suas origens filosóficas, principalmente com as fontes citadas na ética aristotélica; e também nas teológicas, lidas nos dogmas da religião católica por importantes pensadores como Santo Agostinho e São Tomás de Aquino, bem como da Enciclopédia Católica. Sem dúvida, essa escolha da figura gulosa de Ciacco não foi aleatória; tendo-se em vista que está presente em grande parte da obra de Dante a necessidade de instrução intelectual formulada sobre uma metáfora alimentar.

Sendo assim, é justamente sobre a necessidade de instrução intelectual que o estudo foi conduzido a Ulisses, que segundo Dante extrapolou os limites do conhecimento permitido. Mas para que a figura de Ulisses pudesse ser compreendida de uma maneira mais completa, foi proposto, no Capítulo 4, delinear a identidade da personagem através da sua trajetória ao longo da obra de Homero (Ilíada e Odisséia), bem como na obra de alguns poetas latinos indispensáveis para a cultura de Dante, como Ovídio (Metamorfoses), Sêneca (De Constantia Sapientis), Cícero (De Finibus) e, principalmente na obra de seu guia Virgílio (Eneida). Só a partir dessa visão global que se passou à figura do Ulisses dantesco, infinitamente complexo e herdeiro de toda a tradição antiga antes de chegar ao poeta florentino.

No Capítulo 5, sugeriu-se que fossem pensados os atos do Ulisses da Comédia. Com isso, a concepção de incontinência precisou ser ampliada e projetada para dentro das muralhas de Dite, em um contexto em que os condenados são punidos pela intencionalidade fraudulenta de suas ações em vida, não se restringindo, assim, a incontinência à falta de moderação corporal. Com a narrativa de Ulisses, buscou-se discutir se o ardor de ciência da personagem não foi também um ato incontinente, ao buscar um conhecimento não disponível aos homens, 
fato que levou o herói a avistar a montanha do paraíso terrestre; uma sede de saber que foi capaz de superar até mesmo os valores morais e afetivos que Ulisses sabia poder encontrar entre a sua gente. Para tanto, foi necessária uma longa busca sobre como o próprio poeta aproxima $\mathrm{o}$ ato de se alimentar ao, tão imprescindível quanto, ato de se instruir intelectualmente.

Esta pesquisa se baseou na leitura de importantes críticos da obra de Dante, que enxergam na figura do herói grego um forte destaque em relação aos outros condenados do Inferno pela relevância de sua ação. Na maioria dos casos, são esses mesmos críticos que aproximam o valor simbólico que Ulisses carrega consigo ao valor supremo do caráter do poeta, ou seja, a necessidade de entender pra alcançar a completude da alma. Mas, ao contrário do herói incontinente que não soube respeitar os limites dessa racionalidade, o poeta nos revela com a sua visão beatífica, no final do Paraíso, que a complexidade divina está para muito além das capacidades racionais humanas. 


\section{REFERÊNCIAS ${ }^{107}$}

\section{Edições Comentadas da Comédia}

CHIAVACCI LEONARDI, A. M. (Com.). In ALIGHIERI, Dante. La Divina Commedia: Inferno/Purgatorio/Paradiso $1^{\text {a }}$ Edizione. Milano: Mondadori, 2005. 3 Vols.

MATTALIA, Daniele. (Com.). In ALIGHIERI, Dante. La Divina Commedia: Inferno $2^{\mathrm{a}}$ Edizione. Milano: Rizzoli Editore, 1975.

SAPEGNO, Natalino. (Com.). In ALIGHIERI, Dante. La Divina Commedia. $3^{\text {a }}$ Edizione. Firenze: La Nuova Italia, 1993.

\section{Obras e comentários disponíveis em suporte eletrônico}

Dartmouth Dante Project: Banco de dados digital preparado pelo Dartmouth College (USA) que reúne as mais relevantes edições críticas da Comédia, do ano de 1322 ao de 2007: <http://dante.dartmouth.edu/search.php>.

Autores consultados:

- ANONIMO FIORENTINO (1400[?]), Purgatorio 2.52-54. Acesso em 29/04/2010.

- CHARLES S. SINGLETON (1970-75), Paradiso 31.109-111. Acesso em 03/09/2010.

- GIOVANNI BOCCACCIO (1373-75), Inferno 11.79-84. Acesso em 11/05/2010. Inferno 6.34-36. Acesso em 21/05/2010. Inferno 7.117-126. Acesso em 25/05/2010.

- JACOPO DELLA LANA (1324-28), Inferno 9. Nota. Acesso em 05/05/2010. Inferno 6.38-42. Acesso em 28/05/2010.

- L'OTTIMO COMMENTO (3) (1338), Inferno 11.79-90. Acesso em 11/05/2010. - LUIGI PIETROBONO (1946 [1924-30]), Inferno 26.120. Acesso em 05/05/2010.

\footnotetext{
${ }^{107}$ De acordo com a Associação Brasileira de Normas Técnicas.
} 
- NATALINO SAPEGNO (1955-57), Inferno 1. Nota. Acesso em 05/05/2010.

Purgatório 26.18. Acesso em 16/08/2010.

Dante on line: Portal de consulta científica da Società Dantesca Italiana, com toda a obra de

Dante disponível: <http://www.danteonline.it/italiano/home_ita.asp>

Obras consultadas:

- Convivio. Último acesso em 16 de agosto de 2010.

- De Vulgari Eloquentia. Último acesso em 13 de outubro de 2009.

- Epistole. Último acesso em 10 de maio de 2010.

- Questio de Aqua et Terra. Último acesso em 15 de setembro de 2010.

LiberLiber. Biblioteca digital com obras de domínio público: 〈http://www.liberliber.it>.

Obras consultadas:

- GIOVANNI BOCCACCIO. Trattatello in laude di Dante. Acesso em 26 de julho de 2010.

Projeto “Odorico Mendes”. Projeto da Universidade Estadual de Campinas que divulga a obra do maranhense Manuel Odorico Mendes (1799-1864), sobretudo de suas traduções dos clássicos gregos e latinos (todo Homero e todo Virgílio em decassílabos):

<http://www.unicamp.br/iel/projetos/OdoricoMendes>

Obras consultadas:

- Eneida Brazileira. 1a Edição, 1854. Acesso em 08 de Agosto de 2010.

- Virgilio Brazileiro. 1ª Edição, 1858. Acesso em 08 de Agosto de 2010.

\section{III.Traduções da Comédia consultadas}

Traduções integrais: 
MARTINS, Cristiano. (Trad.). AlighIERI, Dante. A Divina Comédia. $8^{\text {a }}$ Edição. Belo Horizonte: Ed. Itatiaia, 2006. [Tradução em verso]

XAVIER PINHEIRO, J. P. (Trad.). ALIGHIERI, Dante. A Divina Comédia. $1^{\text {a }}$ Edição. São Paulo: Edigraf, 1958. [Tradução em verso]

\section{Traduções parciais:}

CAMPOS, Augusto de. Invenção. $1^{\text {a }}$ Edição. São Paulo: Arx, 2003. [Tradução em verso]

CAMPOS, Haroldo de. Pedra e luz na poesia de Dante. $1^{\text {a }}$ Edição. Rio de Janeiro: Imago, 1998. [Tradução em verso]

\section{IV.Obras de Aristóteles}

ARISTÓTELES. Ética a Nicômacos. Trad. Mário da Gama Cury. $4^{\text {a }}$ Edição. Brasília: UnB, 2001.

Ética a Nicômaco. Trad. Edson Bini. 2a Edição. Bauru: Edipro, 2007.

Etica Nicomachea. Trad. Carlo Natali. $4^{\text {a }}$ Edizione. Roma-Bari: Laterza,

2005.

Metafísica. Trad. Edson Bini. Bauru: Edipro, 2006.

De Anima. Trad. M. C. Gomes dos Reis. 1ª Edição São Paulo: Ed. 34, 2006.

Retorica. Trad. Marco Dorati. $1^{\text {a }}$ Edizione. Milano: Mondadori, 1996.

\section{Obras de Virgílio}

VIRGÍlLIO. Eneida. Trad. T. S. Spalding. 1ª Edição. São Paulo: Abril Cultural, 1983.

Eneida. Trad. Carlos Alberto Nunes. 1ª Edição. Brasília: Editora UnB, 1981. 


\section{VI.Estudos sobre Dante}

- ENCICLOPEDIA DANTESCA. $3^{\text {a }}$ Edizione. Roma: Istituto della Enciclopedia Italiana, 1996.

CIOTTI, Andrea. Incontinenza e incontinenti. Tomo III, pp. 415-7.

DE MATTEIS, Maria. Aristotele. Tomo I, pp. 372-7

\section{- OUTROS ESTUDOS}

ARMOUR, P. Dante's contrapasso: context and texts. In: Society for Italian Studies. Vol. LV. Oxford University, 2000.

AUERBACH, Erich. Ensaios de Literatura Ocidental. Trad. Samuel Titan Jr.; José M. M. de Macedo. $1^{a}$ Edição. São Paulo: Ed.34/Duas Cidades, 2007.

Studi su Dante. Trad. Maria Luiza De Pieri Bonino. $4^{\mathrm{a}}$ Edizione. Milano: Feltrinelli, 2008.

BOCCACCIO, Giovanni. Il Commento alla Divina Commedia e gli altri scritti intorno a Dante. Bari: Latera \& Figli, 1918. Vol. II

Decameron. Comentários de Mario Marti e Elena Ceva Valla. 2a Edição. Milão: BUR, 2008.

BORGES, Jorge Luis. Nove ensaios dantescos. In Obras Completas. Trad. Jorge Schwartz [et al.] 1 1 Edição. Rio de Janeiro: Editora Globo, 1999. Vol. III.

. Siete Noches. Madrid: Alianza Editorial, 2007.

CONTINI, Gianfranco. Un'idea di Dante. Saggi danteschi. $3^{\text {a }}$ Edizione. Torino: Einaldi, 2001.

CROCE, Benedetto. La poesia di Dante. 6ª Edizione Riveduta. Bari: Laterza, 1948.

DE SANCTIS, Francesco. Ensaios Críticos. Trad. Antônio Lázaro de A. Prado. $1^{\text {a }}$ Edição. Nova Alexandria: São Paulo, 1993. 
DOTTI, Ugo. La Divina Commedia e la città dell'uomo. $1^{\text {a }}$ Edizione. Roma: Donzelli Editore, 1996.

FUBINI, Mario. Il peccato di Ulisse e altri scritti danteschi. Milano-Napoli: Riccardo Ricciardi, 1963.

INGLESE, Giorgio. Dante: Guida alla Divina Commedia. 1ª Edizione. Roma: Carocci, 2002.

NARDI, Bruno. Dante e la cultura medievale. $2^{\text {a }}$ Edizione. Roma-Bari: Laterza, 1990.

PETROCCHI, Giorgio. Dante e il suo tempo. $1^{\text {a }}$ Edizione. Torino: ERI, 1963.

. Vita di Dante. $4^{\text {a }}$ Edizione. Roma-Bari: Laterza, 2004.

. L’Inferno di Dante. $4^{\text {a }}$ Edizione. Milano: Rizzoli, 1989.

PIETROBONO, Luigi. Dal centro al cerchio: la struttura morale della Divina

Commedia. Torino: Società Editrice Internazionale, 1956.

. Dante e La Divina Commedia. $1^{\text {a }}$ Edizione. Firenze: Sansoni, 1953.

STERZI, Eduardo. Por que ler Dante. São Paulo: Globo, 2008.

VII. Estudos sobre Aristóteles

ALLAN, D. J. A Filosofia de Aristóteles. Trad. Rui Goncalo Amado. $2^{\text {a }}$ Edição. Lisboa: Presença, 1970.

AUBEnQUE, Pierre. A prudência em Aristóteles. Trad. Marisa Lopes. $1^{\mathrm{a}}$ Edição. São Paulo: Discurso Editorial, 2003.

PIEPER, Josef. Virtudes Fundamentais. Trad. Narino e Silva; Beckert da Assumpção. Lisboa: Aster, 1960.

TOMÁS de Aquino, Santo. Sobre o Mal (De malo). Trad. Carlos Ancêde Nougué. Rio de Janeiro: Sétimo Selo, 2005. 
Sobre o Ensino (De Magistro). Os sete pecados capitais. Trad. Luiz Jean Lauand.1 ${ }^{a}$ Edição. São Paulo: Martins Fontes, 2001.

Suma Teológica. $1^{\mathrm{a}}$ Edição. São Paulo: Loyola, 2006. Vol. VII.

\section{Outras obras consultadas}

AGOSTINHO, Santo. Confissões. Trad. Arnaldo do Espírito Santo [et al]. Lisboa: Imprensa Nacional - Casa da Moeda, 2001.

BÍBLIA. Português. Bíblia de Jerusalém. Trad. Euclides M. Balancin [et al.]. São Paulo: Paulus, 2003.

BLAKE, W. Divine Comedy Illustrations. Nova York: Dover Publications, 2008.

BOITANI, Piero. L’ombra di Ulisse. Prima Edizione. Bologna: Il Mulino, 1992.

CAMPOS. Haroldo de. Sobre Finismundo: A última viagem. Rio de Janeiro, Sette Letras: 1996.

CICERO, Marco Tulio. Do sumo bem e do sumo mal (De finibus bonorum et malorum). Trad. Carlos Ancêde Nougué. São Paulo: Martins Fontes, 2005.

CODINO, Fausto. Introduzione a Omero. $2^{\text {a }}$ Edizione. Torino: Einaudi, 1965.

CROCE, Benedetto. Breviário de Estética. Aesthetica in nuce. Trad. Alfredo Bosi. São Paulo: Ática, 1997.

DE LIBERA, Alain de. A Filosofia Medieval. Trad. N. Campanário; Y. M. Teixeira da Silva. $2^{\mathrm{a}}$ Edição. São Paulo: Edições Loyola, 2004.

FRANCO Jr., Hilário. Cocanha: A história de um país imaginário. $1^{\text {a }}$ Edição. São Paulo: Companhia das Letras, 1998.

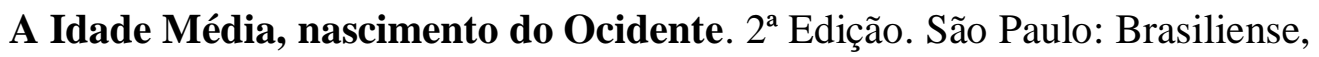
2004. 
GREGÓRIO MAGNO, São. Moralia In: Gregorii Magni opera. Opere di Gregorio Magno. Roma: Città Nuova, 1992.

GRIMAL, Pierre. Virgílio, ou o segundo nascimento de Roma. Trad. Ivone Castilho Benedetti. $1^{\text {a }}$ Edição. São Paulo: Martins Fontes, 1992.

HOMERO. Ilíada. Trad. Carlos Alberto Nunes. Rio de Janeiro: Ediouro, 2001.

Odisséia. Trad. Carlos Alberto Nunes. Rio de Janeiro: Ediouro, 1996.

JAEGER, Werner. Paidéia: a formação do homem grego. Trad. Artur M. Parreira. São Paulo: Martins Fontes, 2001.

LAUAND, Luiz Jean. Cultura e educação na Idade Média. São Paulo: Martins Fontes, 1998.

LE GOFF, Jacques. A civilização do ocidente medieval. Trad. José Rivair de Macedo. Bauru: EDUSC, 2005.

MALTA, André. A selvagem perdição: erro e ruína na Ilíada. São Paulo: Odysseus, 2006.

NASCIMENTO, Carlos A. O que é Filosofia Medieval. $1^{a}$ Edição. São Paulo: Brasiliense, 2004. (Coleção Primeiros Passos)

OVIDIO. Metamorfoses. Trad. Manuel M. Barbosa du Bocage (1765-1805). $1^{\text {a }}$ Edição. São Paulo: Hedra, 2000.

PROSE, Francine. Gula. Trad. Sergio Viotti. $1^{a}$ Edição. São Paulo: Arx, 2004. (Coleção Sete Pecados Capitais).

ROSENSTOCK-HUESSY, Eugen. A origem da linguagem. Trad. Pêdro Sette Câmara [et al.]. Rio de Janeiro: Record, 2002.

SAPEGNO, Natalino. Storia Letteraria del Trecento. $1^{\text {a }}$ Edizione. Milano-Napoli: Riccardo Ricciardi Editore, 1963.

SENECA. Guida alla sagezza (De constantia sapientis). A cura di Mario Scaffidi Abbate. $1^{\text {a }}$ Edizione Roma: Tascabili Economici Newton, 1995. 
STATIUS, Publius Papinius. Ouvres completes de Stace. Paris: Panckoucke, 1832.

\section{IX.Dicionários e outras Enciclopédias}

AUDI, Robert (Dir.). Dicionário de Filosofia de Cambridge. São Paulo: Paulus, 2006.

CITTÀ DEL VATICANO. Enciclopedia Cattolica. Prima Edizione. Città del Vaticano: Ente per il Libro Cattolico e l'Enciclopedia Cattolica, 1951. Tomos VI e IX.

- MORSTABILINI, Luigi. Gola. Tomo VI, p. 903.

- VANNICELLI, Luigi. Peccato. Tomo IX, pp 1014-1027.

GRIMAL, Pierre. Dicionário de Mitologia Grega e Romana. $1^{\text {a }}$ Edição. Rio de Janeiro: Bertrand Brasil, 1997.

GUIMARÃES, Ruth. Dicionário da Mitologia Grega. 1ª Edição. São Paulo: Cultrix, 2002.

HOUAISS. Dicionário eletrônico da língua portuguesa. Versão 1.0. Instituto Antônio Houaiss/Ed. Objetiva, 2001.

LE GOFF, Jacques e SCHMITT, Jean-Claude. Dicionário Temático do Ocidente Medieval.

1ª Edição. Bauru: EDUSC; São Paulo: Imprensa Oficial do Estado, 2002.

- BOUREAU, Alain. Fé. Vol. 1.

- CASAGRANDE, Carla e VECCHIO, Silvana. Pecado. Vol. 2.

- MONTANARI, Massimo. Alimentação. Vol. 1.

- MURRAY, Alexandre. Razão. Vol. 2.

MORA, J. FERRATER. Dicionário de Filosofia. $1^{\text {a }}$ Edição. São Paulo: Edições Loyola, 2000. Tomo III.

ZINGARELLI, Nicola. Lo Zingarelli minore. Vocabolario della lingua italiana. Edizione Terzo Milenio. Bolonha: Zanichelli, 2001. 